University of Michigan Law School

University of Michigan Law School Scholarship Repository

Articles

Faculty Scholarship

2002

\title{
A Control-Based Approach to Shareholder Liability for Corporate Torts
}

Nina A. Mendelson

University of Michigan Law School, nmendel@umich.edu

Available at: https://repository.law.umich.edu/articles/675

Follow this and additional works at: https://repository.law.umich.edu/articles

Part of the Business Organizations Law Commons, Law and Economics Commons, and the Torts Commons

\section{Recommended Citation}

Mendelson, Nina A. "A Control-Based Approach to Shareholder Liability for Corporate Torts." Colum. L. Rev. 102, no. 5 (2002): 1203-303.

This Article is brought to you for free and open access by the Faculty Scholarship at University of Michigan Law School Scholarship Repository. It has been accepted for inclusion in Articles by an authorized administrator of University of Michigan Law School Scholarship Repository. For more information, please contact mlaw.repository@umich.edu. 


\title{
ARTICLE
}

\section{A CONTROL-BASED APPROACH TO SHAREHOLDER LIABILITY FOR CORPORATE TORTS}

\author{
Nina A. Mendelson*
}

Some commentators defend limited shareholder liability for torts and statutory violations as efficient, even though it encourages corporations to overinvest in and to externalize the costs of risky activity. Others propose pro rata unlimited shareholder liability for comporate torts. Both approaches, however, fail to account fully for qualitative differences among shareholders. Controlling shareholders, in particular, may have lower information costs, greater influence over managerial decisionmaking, and greater ability to benefit from corporate activity.

This Article develops a control-based approach to shareholder liability. It first explores several differences among shareholders. For example, a controlling shareholder can more easily curb managerial risk aversion and consequently will likely prompt a company to externalize more costs. Further, because a controlling shareholder can obtain special benefits from corporate activity, imposing pro rata shareholder liability likely will not fully deter overinvestment in risky activities.

This Article then proposes to hold shareholders with a capacity to control corporate activity fully responsible for corporate torts and statutory violations. Compared with the limited liability and pro rata liability regimes, a control-based liability regime is the most likely to compel corporations to internalize their costs and to ensure that injured tort plaintiffs are compensated. However, the regime could potentially overdeter some socially beneficial activities if insurance is unavailable. While definitively resolving the size of such effects requires further empirical investigation, a control-based liability regime more explicitly addresses shareholder differences and appears most likely to address limited liability's moral hazard. This Article accordingly concludes that such a regime offers a promising alternative.

* Assistant Professor of Law, University of Michigan Law School. I am especially grateful for the comments of Omri Ben-Shahar, Steve Croley, Judge Frank Easterbrook, Merritt Fox, Kent Greenfield, Daniel Halberstam, Don Herzog, Rick Hills, Jim Hines, Rob Howse, Ellen Katz, Reinier Kraakman, Riyaz Kanji, Kyle Logue, Ronald Mann, Sallyanne Payton, James J. White, and participants in the Law and Economics Workshop at University of Michigan Law School. I benefited from the able research assistance of Joshua Doan and Peter Nemerovski. I also thank the Cook Fund at the University of Michigan Law School for generous research support. 


\section{TABLE of Contents}

INTRODUCTION ................................... 1204

I. Some Background on Limited Liability .............. 1208

A. The Development of Limited Liability ............. 1209

B. The Relationship Between Corporate Shareholders and Corporate Entities ......................... 1212

II. The EFFicienCy Justification FOR Limited Liability . . . . . 1217

A. Parsing the Efficiency Justification ............. 1219

B. Describing Shareholder Characteristics ........... 1227

III. Excessive Risk Taking Under Limited Liability . . . . . . . 1232

A. The Basic Moral Hazard Problem .............. 1232

B. Preferred Risks Under Limited Liability .......... 1235

C. The Evidence of Excessive Risk Taking .......... 1239

D. The Special Case of the Controlling Shareholder .... 1247

E. Possible Neutralizers ........................ 1259

IV. A Control-Based Shareholder Liability Reglme ....... 1271

A. The Capacity to Control Rule Proposed .......... 1271

B. Comparison of a Control-Based Regime with Other

Regimes ............................... 1279

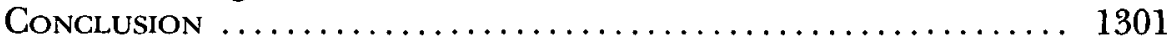

\section{INTRODUCTION}

There is little disagreement that limited shareholder liability for corporate torts ${ }^{1}$ can encourage socially costly corporate activity-risky activity selected because the corporation and its shareholders do not bear all the expected costs of the activity. ${ }^{2}$ While the size of this externality remains to be quantified, individuals engaging in risky business enterprises

1. Shareholder liability for corporate contracts is beyond the scope of this Article. See infra note 122 .

2. See Phillip 1. Blumberg, Limited Liability and Corporate Groups, $11 \mathrm{~J}$. Corp. Law 573,576 (1986) [hereinafter Blumberg, Limited Liability] ("[E]ven economists convinced of the utility of limited liability ... concede that limited liability raises serious problems because it enables the enterprise to externalize its costs."); Paul Halpern et al., An Economic Analysis of Limited Liability in Corporation Law, 30 U. Toronto L.J. 117, 126 (1980) (" [I]t is claimed that a limited liability regime is inefficient because it [creates] incentives for excessive (inefficient) allocations of social resources to risky economic activities."); Henry Hansmann \& Reinier Kraakman, Toward Unlimited Shareholder Liability for Corporate Torts, 100 Yale L.J. 1879, 1879 (1991) [hereinafter Hansmann \& Kraakman, Unlimited Liability] ("II]ncentives [for excessive risk taking] are conventionally assumed to be the price of securing efficient capital financing for corporations."); see also David Leebron, Limited Liability, Tort Victims, and Creditors, 91 Colum. L. Rev. 1565, 1620 (1991) (noting that some arguments "suggest that all shareholders that are corporations ... should be subject to unlimited liability"). This recognition has yet to cause any significant change in judicial willingness to honor limited liability principles. E.g., Browning-Ferris Indus., Inc. v. Ter Maat, 195 F.3d 953, 960 (7th Cir. 1999) (Posner, C.J.) (noting that argument that enterprises "should be prevented from externalizing the costs" of potentially hazardous activities "has not carried the day in any jurisdiction that we are aware of"), cert. denied, 529 U.S. 1098 (2000). 
are regularly advised to create corporations precisely for the purpose of shielding their assets, and corporations engaging in risky activities are advised to create subsidiaries for the same purpose. ${ }^{3}$ Federal government settlement guidelines for civil enforcement actions have explicitly assumed that a corporate defendant's "ability to pay" a government claim generally should be determined without counting shareholder or parent company assets. ${ }^{4}$ Even given the very limited opportunities for "piercing the corporate veil," thousands of corporate tort victims have spent money litigating, trying to obtain compensation from shareholders in cases where corporate assets and insurance may be inadequate to cover injury costs. ${ }^{5}$

Commentary on limited liability for corporate torts falls into two major camps. Some defend limited liability rules against all comers. ${ }^{6}$ Others propose to abandon it altogether in the case of tort and statutory violations and substitute a scheme of unlimited shareholder liability divided among shareholders pro rata. ${ }^{7}$

3. See infra text accompanying notes 177-185.

4. See infra text accompanying notes 150-152.

5. See infra text accompanying note 156 .

6. See, e.g., Frank H. Easterbrook \& Daniel R. Fischel, The Economic Structure of Corporate Law 41-44 (1991) [hereinafter Easterbrook \& Fischel, Economic Structure] (listing advantages of limited liability); Frank H. Easterbrook \& Daniel R. Fischel, Limited Liability and the Corporation, 52 U. Cbi. L. Rev. 89, 104 (1985) [hereinafter Easterbrook \& Fischel, Limited Liability] (“[M]odifying limited liability has its costs and . . moral bazard would exist without limited liability."); infra text accompanying notes 51-63 (discussing efficiency justification for limited liability).

7. See, e.g., Hansmann \& Kraakman, Unlimited Liability, supra note 2, at 1880 (" $[\mathrm{T}]$ here may be no persuasive reasons to prefer limited liability over a regime of unlimited pro rata sharebolder liability for corporate torts."); Leebron, supra note 2, at 1569 ("[I]f unlimited liability were adopted, it should be pro rata."). Christopher Stone also proposes pro rata liability. See Christopher D. Stone, The Place of Enterprise Liability in the Control of Corporate Conduct, 90 Yale. L.J. 1, 74 (1980) ("[E]ach would be liable only in proportion to his or her equity interest."). A third smaller group argues that limited liability should be abandoned only for certain categories of corporations, either closely-held corporations or corporations that are wholly-owned by a parent corporation. E.g., Blumberg, Limited Liability, supra note 2, at 630 ("If a subsidiary corporation constitutes only one of a number of components of a corporate group collectively conducting a fragmented unitary business, the very basis for the establishment of limited liability as a matter of general legal policy disappears." (internal footnotes omitted)); Halpern et al., supra note 2, at 148 (advocating unlimited liability for "small, tightly held companies"). Finally, Stephen Bainbridge proposes to abolish veil piercing altogether as "rare, unprincipled, and arbitrary." Stephen M. Bainbridge, Abolishing Veil Piercing, $26 \mathrm{~J}$. Corp. L. 479, 535 (2001). However, he would permit tort liability to be allocated within a corporate group under enterprise liability approaches. Id. at 527-34. Bainbridge's justification for eliminating veil piercing in tort cases is based on the vagueness of the veil piercing standard, the "expensive litigation" it thus generates, as well as its denial of "certainty and predictability" to investors. Id. at 524. Bainbridge does not, however, consider a control-based liability rule, which is likely to be considerably easier than the current veil piercing rule for courts to apply. Occasionally, commentators have proposed activity-specific or industry-specific solutions, such as compulsory insurance requirements or minimum capitalization requirements. E.g., id. at 524-25; see Joseph Grundfest, The 
Both groups, however, focus on the corporation as the unit. Inexplicably, neither regime seems to account fully for qualitative differences among shareholders. Shareholders may have varying access to information and ability to influence management decisions, and controlling shareholders may have special opportunities to benefit from corporate activity. ${ }^{8}$ A shareholder liability regime's consequences can differ significantly by shareholder. Take limited liability's articulated benefit of reducing information costs. A limited liability regime might indeed save significant costs for a shareholder with only a tiny proportion of a corporation's shares and limited access to information. By contrast, when the shareholder is a parent corporation or a shareholder that otherwise can control corporate affairs, information costs savings may be less significant-or lacking altogether.

The moral hazard created by limited liability for a corporation to overinvest in excessively risky activity also depends on shareholder characteristics. For example, a controlling shareholder will be more able to influence a corporation to take excessive risks because the shareholder will be better able to curb the effects of managerial risk aversion. ${ }^{9}$ Further, a controlling shareholder likely will be more inclined to favor risky corporate projects because of a general ability to reap a share of corporate benefits in excess of a pro rata share. ${ }^{10}$ Consequently, the presence of a controlling shareholder likely will prompt a corporation to externalize more costs than if the corporation's equity is diffusely held by many very small shareholders. However, neither the limited liability regime nor the pro rata regime adequately accounts for the differences in incentives and transaction costs that can face different shareholders in a single corporation.

In contrast, a control-based liability regime would focus vicarious liability for corporate torts and tort-like statutory violations only on the shareholder with the capacity to control the corporation. When liability exceeds corporate assets, a shareholder with the capacity to control would be fully responsible for corporate torts or statutory violations. A controlbased regime would thereby respond to the greater incentive for exces-

Limited Future of Unlimited Liability: A Capital Markets Perspective, 102 Yale L.J. 387, 421 (1992) (mentioning "leading alternatives" to shareholder liability rule changes, including minimum capitalization requirements). To meaningfully solve the problem of excessive risk taking, however, these solutions require government to anticipate the risks accompanying a wide variety of corporate activities, despite government's likely inferior access to information. See Bainbridge, supra, at 525 ("Only with hindsight can one determine accurately how much capital or insurance will be necessary for any given corporation."); cf. Reinier Kraakman, Corporate Liability Strategies and the Costs of Legal Controls, 93 Yale L.J. 857, 873-74 (1984) (comparing minimum insurance or "adequate" capitalization with managerial liability and noting that managerial information access is likely to be superior to that of legislators).

8. See infra Part III.D.

9. See infra text accompanying notes 196-200.

10. See infra text accompanying notes 206-231. 
sive risk taking resulting from the presence of a controlling shareholder. It also would address a potential shortcoming of the pro rata unlimited liability regime: the prospect that its incentives for controlling shareholders might be inadequate to deter excessive corporate risk taking. At the same time, because it would not treat shareholders identically, a controlbased liability regime could preserve potential efficiencies created by limited liability for truly small shareholders, such as reductions in transaction costs. A control-based liability regime is not free from disadvantages. It could overdeter some socially beneficial activities that cannot be insured, and the application of a more flexible liability standard could generate transaction costs compared with a detailed ex ante rule. Definitively resolving the relative size of these effects requires further empirical investigation into issues such as the value of control and the location and significance of transaction costs. Nonetheless, because a control-based liability regime more explicitly responds to differences among shareholders and appears most likely to compel corporations to internalize the costs of their risky activities, it deserves serious consideration.

A control-based liability regime deserves such consideration for pragmatic reasons as well. Implementing it would be comparatively straightforward. Of course, retaining the status quo is generally easiest-but that would also require retaining the undiluted moral hazard of limited liability. However, compared with a pro rata liability regime, a control-based liability regime could be more easily adopted. Congress or state legislatures could pass statutes imposing such a regime, and courts could also implement it by simply building on the common law rules of veil piercing. ${ }^{11}$

Part I of this Article briefly summarizes the history of the limited liability regime and discusses how limited liability arose separately from a host of other features typically associated with an independent corporate form. Part Il outlines the prevailing justification for limited liabilitylimited liability as an efficient investment incentive-and discusses how it critically depends on positing a "typical" corporation as one owned by numerous small shareholders and a "typical" shareholder as an individual without great wealth or the ability to control the corporation. It then questions the justification in view of current data regarding corporate equity holders and the distribution of ownership in domestic private and public corporations. Part III discusses limited liability's moral hazard and how it is exacerbated by the presence, within a corporation's ownership, of a controlling shareholder. It also responds to arguments that other aspects of the current legal system may tend to blunt the moral hazard. Part IV outlines the basic framework of a control-based liability regime,

11. Both the issue of transition rules and whether such a step would best be taken at the state or federal level are beyond the scope of this paper. For a discussion of this latter issue, see, e.g., Janet Cooper Alexander, Unlimited Shareholder Liability Through a Procedural Lens, 106 Harv. L. Rev. 387, 389 (1992) (arguing that expansion of vicarious liability by state statute would present claimants with siguificant procedural difficulties). 
which would impose liability on a shareholder that possesses the capacity to control a corporation. It then compares the control-based regime to limited liability and to a pro rata regime of shareholder liability. Part IV includes an analysis of a control-based liability regime's potential disadvantages, including the prospect that when insurance is unavailable, shareholders might turn away from socially beneficial corporate opportunities. Part IV further argues that, despite these disadvantages, a controlbased regime is still preferable to a pro rata regime because a pro rata rule would inadequately address limited liability's moral hazard. Because a controlling shareholder can obtain value from corporate operations in excess of the shareholder's pro rata share, the shareholder would still face incentives to encourage a corporation to underinsure and to take excessive risks. Further, under a pro rata regime, substantial transaction costs are likely to hinder plaintiffs from obtaining full compensation from multiple corporate shareholders. A capacity to control regime is likely to better assure that corporations internalize the costs of risky corporate activity, including through adequate insurance.

\section{SOME BaCkground ON Limited LiabiLity}

The corporation has become the dominant form of American business organization. In 1998, business done in the corporate form amounted to $\$ 37$ trillion worth of receipts, compared with $\$ 1$ trillion of receipts attributable to partnerships and sole proprietorships combined. ${ }^{12}$ The presumed availability of limited liability for shareholdersa characteristic that has typically been associated with the corporate form ${ }^{3}$ - could well be a reason for the corporate form's dominance. According to some commentators, limited liability "is regarded by most per-

12. In 1998, at least 4.7 million corporations filed tax returns with the 1RS. U.S. Internal Revenue Service, Number of Business Income Returns, 1980-1998 (on file with the Columbia Law Review). In the same year, the IRS received 1.8 million returns from partnerships and 17 million returns from proprietorships. Id. Further, the total number of corporate tax returns understates the number of domestic corporations, since some corporate groups file a single consolidated tax return.

The overwhelming majority of corporations are not publicly traded. For example, the New York Stock Exchange lists just under 3000 corporations-less than $0.1 \%$ of the total number of corporations that filed tax returns with the IRS. New York Stock Exchange, Fact Book for the Year 2000, at 5 (2001) [hereinafter NYSE Facts 2000].

13. Among other typical corporate features are a corporation's legal existence and capacity to act separately from the identity and actions of its owners, continuous succession (an existence separate from the changes in its membership), unified management, the power to sue and be sued, and the ability to take or convey property in the corporate name. Arthur W. Machen, Jr., Corporate Personality, 24 Harv. L. Rev. 253, 258-67 (1911); see 1 Joseph Stancliffe Davis, Essays in the Earlier History of American Corporations 5 (1917) (stating that a corporation was "[as early as the American colonial period], as now, a group of individuals authorized by law to act as a unit"). 
sons as the greatest advantage of incorporation" and "perhaps the distinguishing feature" of corporate law. ${ }^{14}$

\section{A. The Development of Limited Liability}

Despite its current status, limited liability for corporate shareholders has not always been associated with corporations. It arose separately from and apparently later than the other characteristic corporate features, such as the capacity to take legally binding action. ${ }^{15}$ Early on, some American states, such as Maine, Massachusetts, and Rhode Island,

14. I. Maurice Wormser, Disregard of the Corporate Fiction and Allied Corporation Problems 14 (1927); Easterhrook \& Fischel, Economic Structure, supra note 6, at 40. Limited liability has been called "'the greatest single discovery of modern times . . . even steam and electricity are far less important." " William Rands, Domination of a Subsidiary by a Parent, 32 Ind. L. Rev. 421, 422 (1999) (quoting unnamed Columbia University president); see LaBelle v. Crepeau, 593 A.2d 653, 655 (Me. 1991) (stating that principal benefit of corporate form "is limited liability for shareholders"); Halpern et al., supra note 2, at 118 ("The economic historian of the future may assign to the nameless inventor of the principle of limited liability ... a place of honour with Watt and Stephenson, and other pioneers of the Industrial Revolution.'") (quoting Economist, Dec. 18, 1926); see also Richard G. Lipsey et al., Economics 174 (9th ed. 1990) ("From a stockholder's viewpoint, one of the most important aspects of the corporation is its limited liability."); James B. Zimpritch, Maine Corporation Law \& Practice $\$ 4.5$ (Supp. 1992) ("A principal purpose in most incorporations is to obtain limited shareholder liability."); Lynn M. LoPucki, Virtual Judgment Proofing: A Rejoinder, 107 Yale L.J. 1413, 1427 (1998) [hereinafter LoPucki, Judgment Proofing] ("Limiting liability is widely understood to be the principal reason for the separate incorporation of subsidiaries."). Limited liability is also characterizing new forms of organization, such as the Limited Liability Partnership (LLP) and the Limited Liability Company (LLC). Hansmann and Kraakman have recently argued, however, that the essential aspect of corporate personhood should be understood, if anything, as the "reverse of limited liability"-ensuring that the assets of a corporation (or other legal entity) are sbielded from "claims of the creditors of the entity's owners or managers." Henry Hansmann \& Reinier Kraakman, The Essential Role of Organizational Law, 110 Yale L.J. 387, 390 (2000).

15. See James Williard Hurst, The Legitimacy of the Business Corporation in the Law of the United States, 1780-1970, at 19 (1970) (noting development of other features beginning in late eighteenth century); see id. at 26 ("On balance, and from the outset, the corporation was an instrument to provide firm central direction for the enterprising use of pooled assets."); see id. at 27 (noting development of judge-made law of limited liability beginning in early nineteenth century); Blumberg, Limited Liability, supra note 2, at 588 (noting businessmen used corporate form "primarily to achieve perpetuity of existence and ready transferability of shares"); id. at 576 (noting substantial industrial development in corporate form "before limited liability emerged in the United States around 1825"). English corporation law similarly did not consider limited liability, at the outset, to be "among the essential attributes of the corporation." Id. at 579-80 (discussing Coke, Blackstone, and Kyd); E. Merrick Dodd, The Evolution of Limited Liability in American Industry: Massachusetts, 61 Harv. L. Rev. 1351, 1356 (1948) ("[E]ven in England, the evidence as to what the men of the eighteenth century thought on [the subject of limited liability] is extremely meager and in the United States it is almost nonexistent."). Early American corporate charters did not discuss liability at all. .1d. ("Several of the early Massachusetts manufacturing corporation charters were completely silent with respect to what rights, if any, corporate creditors would have against individual shareholders."). But see 1 Davis, supra note 13 , at 5 ("Normally [corporate] property was not liable for 
granted corporate charters with the express proviso that shareholders would be fully liable-apparently on the theory that unlimited liability would best ensure economic growth and development because creditors, assured of repayment, would loan more capital. ${ }^{16}$ Many states had enacted provisions expressly holding shareholders liable for amounts in excess of the value of their shares. ${ }^{17}$

Eventually, however, most state legislatures chose limited liability as the best means of encouraging investment and thereby economic growth. ${ }^{18}$ By 1840 , most state legislatures had determined that the "furthering of capital formation could best be accomplished by encouraging shareholders to invest through limiting their liability." 19 Perceived targets of these incentives were apparently the "small-scale entrepreneur" and companies with public functions, ${ }^{20}$ but large-scale industrialists prob-

obligations of members, and their private property was likewise not subject to be taken to pay debts of the corporation.").

The ability to take legally binding action was not always vested in a board of directors, but sometimes was dependent on significant shareholder involvement. See Hurst, supra, at 25 (giving examples and stating that "courts were at first hesitant to recognize implied powers in boards of directors"); Morton J. Horwitz, The Transformation of American Law, 1870-1960, at 87-89 (1992) (discussing need for unanimous or majority shareholder vote for some transactions).

16. See Dodd, supra note 15, at 1375-76; Stephen B. Presser, Piercing the Corporate Veil § 1.03[1] (2001) [hereinafter Presser, Piercing]; Stephen B. Presser, Thwarting the Killing of the Corporation: Limited Liability, Democracy, and Economics, 87 Nw. U. L. Rev. 148, 155 (1992) [hereinafter Presser, Thwartingl.

17. See Blumberg, Limited Liability, supra note 2, at 588-89 (noting presence of direct or indirect shareholder liability in several industrial states); Hurst, supra note 15, at 27 (noting that shareholders in industrial states sometimes faced double their investment or more in liability for particular debts). The common law had, however, "evolved to the point of presuming limited shareholder liability in the absence of any legislative rule" by the mid-1800s. Horwitz, supra note 15, at 94 .

Through this period, the corporation was still perceived as not dissimilar to a partnership in the sense that a corporation could be seen as a group of shareholders acting in concert, rather than an entity sui generis. For example, Professor Horwitz notes that in the $1880 \mathrm{~s}$, a corporation could not sell its assets without unanimous shareholder consent. ld. at 87-88. In that sense, the distinction between corporate shareholder liability and the liability of a member of a partnership was largely a "matter of degree." Id. at 94.

18. See Blumberg, Limited Liability, supra note 2, at 604 (noting that limited liability was "intended to stimulate economic activity by encouraging widespread investment in corporate shares"). Evidence on whether the change in approach actually did encourage investment during the early period is mixed. For example, "Rhode Island . . . adhered to the full-liability principle until 1847 without thereby losing its position as the second state in the union in the value of its cotton-textile products." Dodd, supra note 15, at 1376 (footnote omitted).

19. Presser, Thwarting, supra note 16 , at $\mathbf{1 5 5 .}$

20. Id.; see also Halpern et al., supra note 2, at 118 (explaining that limited liability supporters in England argued that middle and working classes would be encouraged to invest); Blumberg, Limited Liability, supra note 2, at 593 (noting earlier acceptance of limited liability for companies with "public function or financial objectives"). 
ably pressured the political process for limited liability. ${ }^{21}$ By the late 1800 s, most states had begun to grant at least some limited liability corporate charters. ${ }^{22}$ Even with these decisions, limited corporate shareholder liability was far from fully established until the early part of the twentieth century. ${ }^{23}$

Now, however, the overwhelming majority of state corporation statutes, which provide the "default terms" under which companies may incorporate, include express limitations on shareholder liability. Section 6.22 of the Model Business Corporation Act specifies that the shareholder's obligation to the corporation is solely to "pay the consideration for which the shares were authorized to be issued." 24 A shareholder is "not personally liable for the acts or debts of the corporation except that he may become personally liable by reason of his own acts or conduct." ${ }^{25}$

21. See Blumberg, Limited Liability, supra note 2, at 592-93 (noting that industrialists "pressed" for extension of limited liability).

22. See Dodd, supra note 15 , at $1375-78$.

23. Horwitz, supra note 15 , at 94 (" $[T]$ ruly limited shareholder liability was far from the norm in America even as late as 1900.”). Compare Thomas Gold Frost, A Treatise on the Incorporation and Organization of Corporations $\$ 16$ (1906) ("It has been the rule of the courts from time immemorial to recognize and enforce the power of the corporations to sue and be sued . . . as incident to such corporate existence."), with id. $\$ 65$ (noting special requirements in several states before stockholders may avoid personal liability for corporate debts).

24. Model Bus. Corp. Act $\$ 6.22$ (a) (1985).

25. 1d. $\S 6.22(\mathrm{~b})$. See generally Presser, Piercing, supra note 16, $\S \$ 2.01-.52$ (reviewing state laws on corporate veil piercing). Section 6.22(b) of the Model Business Corporation Act has been adopted in Arkansas, Colorado, Connecticut, Georgia, Hawaii, Idaho, Indiana, Kentucky, Michigan, Mississippi, Montana, Nebraska, New Hampshire, North Carolina, Oregon, South Carolina, Tennessee, Vermont, and Wyoming. Ark. Code Ann. § 4-27-622 (Michie 1987); Colo. Rev. Stat. Ann. § 7-106-203 (West 1999); Conn. Gen. Stat. Ann. § 33-673 (West 1997); Ga. Code Ann. § 14-2-622 (1994); Haw. Rev. Stat. Ann. § 414-83 (Michie 2001); ldaho Code § 30-1-622 (Michie 1999); Ind. Code Ann. § 23-1-26-3 (Michie 1999); Ky. Rev. Stat. Ann. \$ 271B.6-220 (Michie 1989); Mich. Comp. Laws Ann. $\S 450.1317$ (West 1990); Miss. Code Ann. $\S 79-4-6.22$ (1972); Mont. Code Ann. § 35-1-534 (2001); Neb. Rev. Stat. § 21-2041 (1997); N.H. Rev. Stat. Ann. § 293-A:6.22 (1999); N.C. Gen. Stat. § 55-6-22 (1999); Or. Rev. Stat. \$ 60.151 (1988); S.C. Code Ann. § 33-6-220 (Law. Co-op. 1990); Tenn. Code Ann. § 48-16-203 (1995); Vt. Stat. Ann. tit. 11A, § 6.22 (1997); Wyo. Stat. Ann. $\S 17-16-622$ (Micbie 1996). The statutes of Arizona, Iowa, and Utah state generally that a shareholder is not personally liable for the acts or debts of the corporation. Ariz. Rev. Stat. Ann. § 10-622 (West 1996); Iowa Code Ann. § 490.622 (West 1999); Utah Code Ann. $\$ 16-10 \mathrm{a}-622$ (2001). Absent an express statement in the articles of incorporation, Delaware's statute similarly removes personal liability of shareholders for the "payment of the corporation's debts except as they may be liable by reason of their own conduct or acts." Del. Code Ann. tit. 8, $\$ 102(b)(6)(2001)$. Generally, the states limit shareholder liability by statute. See William L. Cary and Melvin Aron Eisenberg, Corporations 165 (7th ed. 1995) ("The basic rule of corporate law is the statutory rule of limited liability.").

Two exceptions are the New York and Wisconsin statutes, wbich impose liability on shareholders for employee wage claims if the corporation fails to satisfy those claims. New York's default articles of incorporation impose liability on the ten largest shareholders of a corporation. N.Y. Bus. Corp. Law $\S 103$ (McKinney 1986) (applies to all corporations); id. $\S 630$ (imposing joint and several liability on ten largest shareholders of corporations, 


\section{B. The Relationship Between Corporate Shareholders and Corporate Entities}

Historical evidence suggests that limited liability was developed as a broad-based investment subsidy. ${ }^{26}$ As discussed below, limited liability also serves to encourage excessively risky activity by permitting companies to externalize costs for which they would otherwise be compelled to pay tort damages. Possibly mindful of the social costs resulting from this "moral hazard," commentators have sought to go beyond the historical evidence and articulate more persuasive justifications for limited liability.

In the early part of the century, some commentators suggested that limited liability was justified because the corporation had a legal status "independent" of its shareholders. Corporate activities were distinct from shareholder activities, and a change in shareholder ownership would not necessarily affect the corporate enterprise. ${ }^{27}$ In other words, the corporation is like a new person: The "state's approval of the corporate form sets up a prima facie case that the assets, liabilities, and operations of the corporation are those of the enterprise." 28 And natural persons, of course, have liability limited to their own property. ${ }^{29}$

excepting "investment compan [ies]"); see also Grossman v. Sendor, 392 N.Y.S.2d 997, 999 (Sup. Ct. 1977) (applying section 630). Wisconsin makes all shareholders personally liable for wage claims, but limits their responsibility to the "par value of shares owned by them respectively." Wis. Stat. Ann. \$180.0622 (West 1992).

26. See supra text accompanying notes 18-21; see also Easterbrook \& Fischel, Economic Structure, supra note 6, at 44 ("The increased availability of funds for projects with positive net values is the real benefit of limited liability.").

A related justification, though one that has received little promotion in the limited liability literature, is that limited liability can be justified by the "positive externalities" businesses produce, such as employment and taxes. Because the vast majority of such benefits are priced and traded in well-functioning markets, however, they generally cannot be conceptualized as externalized. Rather, businesses can internalize the value of the benefits by charging for them. For example, the value employment provides to employees is reflected in wage levels. Similarly, the value of new products is generally reflected in the prices charged. See generally Joseph Stiglitz, Economics 154-57 (2d ed. 1997) (describing role externalities play in pricing of goods). Although corporations pay taxes, which could be conceptualized as a positive externality, they also benefit from the public goods funded by those taxes, such as highways and other infrastructure. While some businesses might produce goods with positive externalities (for example, unpatentable basic research), a blanket subsidy for corporate shareholders to reward "positive externalities" is likely both overbroad in that it rewards all corporations irrespective of activity and underinclusive to the extent it does not reward partnerships or sole proprietorships. Positive externalities would be more appropriately compensated through the use of targeted subsidies. Cf. infra text accompanying notes 373-374 (discussing targeted subsidies for industries such as those engaged in pharmaceutical research).

27. See Horwitz, supra note 15, at 100-07 (discussing "entity theory").

28. Adolph A. Berle, Jr., The Theory of Enterprise Entity, 47 Colum. L. Rev. 343, 344 (1947). Berle's language evokes the historical strain in corporation theory that sees the corporation as a creature of the state. See, e.g., Horwitz, supra note 15, at 71-72 (discussing "grant" theory of corporations in nineteenth-century America and view that corporation is an "entity created by the state").

29. Natural persons have limited liability in the sense that courts will only enforce a liability judgment against a person's property. A person retains the ability to work, an 
This justification has been largely abandoned, except for echoes in the occasional judicial opinion. ${ }^{30}$ As shown by its development independent from the development of the corporation, limited shareholder liability clearly seems to be an "attribute of the investment rather than of 'the corporation.'" 31 Another limited liability justification-based on efficiency arguments-has now assumed the dominant position and is discussed below. ${ }^{32}$

Nonetheless, the "artificial person" justification is worth considering if only because its rhetoric suggests the need for a close look at the reality of the relationship between corporate shareholders and corporate entities. The "artificial person" justification suggests substantial corporate independence from shareholders. That seems apt for the corporation composed of numerous individual shareholders, each of which individually holds only a tiny percentage of shares-the Berle-Means corporation. ${ }^{33}$ As a practical matter, such a corporation is management-controlled. The individual shareholder's ability to influence corporate management is very limited, and the shareholder is largely powerless with regard to a particular operational or financial decision. ${ }^{34}$

But the shareholder's relationship with the Berle-Means corporation is quite different from the shareholder's relationship with the company wholly owned by a parent or by a few entities or individuals. In the latter, the shareholder or shareholders may possess considerable potential or actual influence over the corporation's activities. A shareholder may be able to control capital investments, dividend payments, and operational decisions. Although the shareholder may not be able to directly bind the

important income-producing asset, even after declaring bankruptcy. See Lynn M. LoPucki, The Death of Liability, 106 Yale L.J. 1, 9 \& nn.21-22 (1996) [hereinafter LoPucki, Death of Liability] ("imprisonment for debt offends deeply held American values").

30. E.g., United States v. Sharon Steel Corp., 681 F. Supp. 1492, 1498 (D. Utah 1987) (discussing termination of shareholder liability after corporate dissolution in terms of whether corporation is "dead" or "dead [and] buried").

31. Easterbrook \& Fischel, Economic Structure, supra note 6, at 11; see also Blumberg, Limited Liability, supra note 2, at 595 (arguing that limited liability arose as a "political response to economic and political pressures, rather than as a necessary consequence of the entity concept"). This point is easily demonstrated by the fact that a court's piercing of a corporate veil to hold a shareholder responsible for corporate misconduct does not destroy the corporation's legal capacity to act.

32. See infra Part II.

33. Adolf A. Berle \& Gardiner C. Means, The Modern Corporation and Private Property 47-65 (1932).

34. For such corporations, management is primarily conducted by the corporation's officers and other managers, and the law grants shareholders only minimal checks on manager decisionmaking. For example, in shareholder derivative actions, the "business judgment rule" accords significant latitude to corporate managers. Implicit in that rule is the concept that corporate decisions are those of the corporation; the managers possess some autonomy relative to shareholder desires. See In re Caremark Int'l, Inc., 698 A.2d 959, 967-68 (Del. Ch. 1996). 
corporation, ${ }^{35}$ the practical reality is that the shareholder and corporation are not very separate. The corporate form is relatively manipulable and controllable. At the outset, for example, the shareholder could have incorporated the corporation to limit the shareholder's assets at risk from a particular activity conducted by the corporation. The shareholder can also, through membership on or control over the board of directors, see that the corporation is operated to continue to keep assets separate from risky corporate activities through, for example, the prompt payment of dividends or the use of subsidiaries. ${ }^{36}$ Here, the corporation is far from "independent" of the shareholders.

Consider the relationship of the Pacific Gas and Electric Company, the public utility serving northern and central California, and its parent company, the PG\&E Corporation. Although the example does not relate to tort liability, it provides an illustration of close shareholder control by a majority shareholder. Together with a subsidiary, the PG\&E Corporation holds $100 \%$ of the Pacific Gas and Electric Company's common stock and $95 \%$ of its total voting stock, obviously giving it control over the company's board. ${ }^{37}$ When California suffered a major energy shortage in 2000 and 2001, Pacific Gas and Electric Company requested a substantial rate increase to help it meet the costs of providing energy to utility customers, arguing that it had insufficient cash reserves to cover spikes in wholesale energy prices. Pacific Gas and Electric Company later filed for bankruptcy. ${ }^{38}$ An independent audit revealed, however, that between 1997 and 1999 the company had sent $\$ 4.1$ billion to its parent company that in turn was used for dividends, stock repurchases, and investments in other subsidiaries. These payments depleted the corporation's cash reserves, raising the question whether it had been adequately funded to cope with a potential rise in the wholesale price of energy. ${ }^{39}$ The transfer benefited the parent and its other companies, however: The nearly $\$ 1$

35. See Cary \& Eisenberg, supra note 25 , at 118 (stating that a shareholder "as such, has no right to bind the corporation to a contract").

36. See infra text accompanying notes 163-167, 204 (discussing State Dep't of Envtl. Prot. v. Ventron Corp., 468 A.2d 150 (N.J. 1983), in which parent exercised control over subsidiary to pay itself dividend of more than $75 \%$ of land held by subsidiary); infra text accompanying note 205 (discussing Walkovszky v. Carlton, 223 N.E.2d 6 (N.Y. 1966)). In Walkovszky $v$. Carlton, the sole shareholder of several taxicab corporations had them constantly pay him dividends, which effectively limited corporate ability to pay tort judgments: "[A]ll income was continually drained out of the corporations for the same purpose." 223 N.E.2d at 11 . While a natural person could theoretically transfer away her assets to avoid liability as well, such a move is likely to be deterred by the resulting loss of use of the assets.

37. See PG\&E Corporation, Pacific Gas \& Electric Company, Joint Notice of 2001 Annual Meetings and Joint Proxy Statement 1 (Apr. 16, 2001) (on file with the Columbia Law Review).

38. Laura M. Holson, California's Largest Utility Files for Bankruptcy, N.Y. Times, Apr. 7, 2001, at A1.

39. Laura M. Holson, Audits Fuel Debate on Curbing California Power Shortage, N.Y. Times, Jan. 31, 2001, at A16. 
billion investment in subsidiaries facilitated the ability of a sister subsidiary, National Energy Group, to buy unregulated power plants and to grow, in only ten years, to become the nation's third largest unregulated utility. ${ }^{40}$

In the last couple of decades, the reality of corporate ownership has moved toward greater ownership concentration, less like the hypothesized Berle-Means corporation and more like the relationship between PG\&E Corporation and Pacific Gas \& Electric Company. A substantial number of American corporations have significantly concentrated ownership or else are susceptible to direct control by particular shareholders. While empirical research in this area is far from exhaustive, several pieces of evidence support this conclusion. First, nearly half the corporate income tax returns filed with the IRS are S Corporation returns. ${ }^{41}$ Chapter $\mathrm{S}$ Corporations must be completely owned by seventy-five or fewer individual shareholders to qualify for special tax treatment. ${ }^{42}$ Over $90 \%$ of $\mathrm{S}$ Corporations are owned by three or fewer shareholders. ${ }^{43}$ More generally, approximately $60 \%$ of close corporations, both S and C corporations, have a shareholder that owns $51 \%$ or more of the equity. Seventy-nine percent of close corporations have a shareholder that holds $50 \%$ or more of the equity. ${ }^{44}$ Moreover, of all active corporations filing tax returns with the $1 R S$ in $1994,74 \%$ reported that they received dividends from a company in which they held $20 \%$ or more of the equity. ${ }^{45}$

Second, in the largest publicly-traded corporations, despite stock exchange requirements of significant numbers of shareholders, ${ }^{46}$ stock ownership is often concentrated. Harold Demsetz has reported that "roughly speaking, about $50 \%$ of large corporations fall into the owner-

40. Richard A. Oppel, Jr. \& Laura M. Holson, While a Utility May Be Failing, Its Owner Is Not, N.Y. Times, Apr. 30, 2001, at A1.

41. Susan Wittman \& Robert Grant, S Corporation Returns, 1996, Stat. Income Bull. (Internal Revenue Serv.), Spring 1999, at 40, 40. S Corporations constitute a "small though growing percentage" of corporate net income. For Tax Year 1996, S Corporation income represented $17.6 \%$ of corporate net income. Id. at 42 .

42. Myron Scholes et al., Taxes \& Business Strategy 80 (2002).

43. Less than $10 \%$ of $S$ Corporations had four or more shareholders. Ninety-nine percent had ten or fewer shareholders. Wittman \& Grant, supra note 41 , at 42.

44. Venky Nagar et al., Ownership Structure and Firm Performance in Closely-held Corporations 28 (June 2000), available at http://papers.ssrn.com/ paper.taf?abstract_id=234336 (on file with the Columbia Law Review). The analysis is based on a 1992 Federal Reserve Board survey of a sample of small, nonfarm, nonfinancial firms from the National Survey of Small Business Finances. See id. at 9.

45. Of 4.8 million active corporation returns, 4.5 million corporations reported that they received dividends from domestic corporations in which they owned $20 \%$ or more of the equity. See Internal Revenue Service Statistics of Income, 1994 Corporation Income Tax Returns, tbl.20 (1997). The data is likely to represent an undercount of subsidiaries because consolidated reporting is permitted for $95 \%$-owned subsidiaries.

46. See, e.g., NYSE Facts 2000 , supra note 12 , at 37 (noting that 500 shareholders at minimum are required for initial listing). 
controlled category." 47 Two economists have identified over 650 publiclytraded companies with majority shareholders. While the study did not also specifically identify companies with a minority shareholder possessing a significant portion of equity-enough to confer on the shareholder the capacity to control the corporation-the data is strongly suggestive that a substantial number of public corporations are likely to be far from the Berle-Means type. ${ }^{48}$

Third, wholly- and mostly-owned subsidiaries are obviously far from independent of their parent corporations. Over seventy-five percent of corporate subsidiaries are wholly owned. ${ }^{49}$ Because parent corporations and their subsidiaries very often file consolidated tax returns, it is extremely difficult to estimate the amount of economic activity attributable to corporate subsidiaries, but in view of the large numbers of corporate subsidiaries, it is probably quite significant. Twenty-two firms randomly

47. Harold Demsetz, The Structure of Ownership and the Theory of the Firm, 26 J.L. \& Econ. 375, 388 (1983). Although Demsetz reaches a conclusion on the presence of ownership control, he is unclear as to the precise criteria for "owner-controlled." He observes that the term could refer to the satisfaction of any of a number of different standards, ranging from the percentage of outstanding shares held by the largest shareholder to the percentage held by the twenty largest shareholders, and the "number so identified varies inversely with the toughness of the criterion adopted." Id. at 388; see also Harold Demsetz \& Belén Villalonga, Ownership Structure and Corporate Performance 13 (2001) (unpublished manuscript, on file with the Columbia Law Review) (observing in sample of 223 firms, "the fraction [of shares] owned [by the five largest shareholders] exceeds $20 \%$ in $60 \%$ of the firms in the sub-sample that excludes the regulated sector").

48. Clifford G. Holderness \& Dennis P. Sheehan, The Role of Majority Shareholders in Publicly Held Corporations, 20 J. Fin. Econ. 317, 319 (1988). Holderness and Sheehan exclude companies in which one shareholder has a stake of $95 \%$ or more, in order to exclude wholly-owned subsidiaries. 1d. at 320. To provide some context for Holderness and Sheehan's figures, approximately 8400 companies are currently listed on the three major stock exchanges-the New York Stock Exchange, the American Stock Exchange, and the NASDAQ. These include non-U.S. companies. See NASDAQ in Black and White 4-4 (2001), available at http://www.nasdaq.com/about/NBW01_Sec04.pdf (on file with the Columbia Law Review); NYSE Facts 2000, supra note 12, at 5 (noting that there are 2862 NYSE-listed companies; domestic operating companies had global market capitalization of $\$ 17.1$ trillion). Holderness and Sheehan apparently did not search for companies with a shareholder with capacity to control that held less than $51 \%$ of shares.

It is worth noting that in a recently conducted smaller study, only $10 \%$ of forty selected publicly-held corporations were found to have a shareholder with a $20 \%$ or larger ownership block. See Mark J. Roe, Political Preconditions to Separating Ownership from Corporate Control, 53 Stan. L. Rev. 539, 562, 604 (2000). The firms Roe selected were the twenty largest publicly-held firms and the first twenty publicly-held firms with market capitalization above $\$ 500$ million. As Roe notes, "Perhaps there is a size beyond which only public firms can exist, because, for example, private parties lack the wealth to take on a major ownership interest." Id. at 563.

49. Leebron, supra note 2, at 1620 (citing Blumberg, Limited Liability, supra note 2, at 626); see also David W. Leebron, Games Corporations Play: A Theory of Tender Offers, 61 N.Y.U. L. Rev. 153, 162 n.35 (1986) (stating that vast majority of corporate acquisitions by tender offer result in ownership of entire equity). 
selected by James J. White from the petroleum, chemical, and pharmaceutical industries had, in 1996, on average, eighty subsidiaries. ${ }^{50}$

Current data on the structure of corporate ownership, while not conclusive, suggests that most corporations have only one or a few controlling shareholders. While many of these corporations are small, a substantial share of corporate economic activity probably is attributable to corporations that fit the "controlling shareholder" form. So, even if ownership and control are not vested in exactly the same entities, they are closely linked in a substantial number of American corporations representing an important part of corporate economic activity. Rather than functioning largely independently of shareholders, these corporations more likely function as instruments of shareholders.

\section{The Efficiency Justification for Limited Liability}

The primary justification for limited liability for corporate torts is efficiency-based: ${ }^{51}$ Limited liability not only encourages investment in socially beneficial activities, but, by addressing market imperfections, it encourages an efficient level of investment. ${ }^{52}$ For limited liability in tort, the argument is that limited liability efficiently facilitates economic investment in two ways: (1) by reducing information costs, thereby facilitating the efficient separation of "capital" from "skill"; and (2) by correcting risk aversion among shareholders.

According to the information costs justification, limited liability efficiently enables individuals with money, but with neither the skill nor the information needed for business management, to invest in the enterprises of others. ${ }^{53}$ Under unlimited liability, ${ }^{54}$ a small investor could con-

50. James J. White, Corporate Judgment Proofing: A Response to Lynn LoPucki's The Death of Liability, 107 Yale L.J. 1363, 1388 n.97 (1998).

51. Another limited liability justification-that limited liability is justified as a means of democratizing opportunities to obtain wealth-applies explicitly to the shareholder with a small budget. Presser, Piercing, supra note 16, $\$ 1.03$ [1]; Presser, Thwarting, supra note 16 , at 154. The argument that limited liability functions as an efficient default term in contracts between corporate creditors and shareholders will not be considered further here, as it does not address the situation of tort creditors. See Easterbrook \& Fischel, Economic Structure, supra note 6, at 41 ("If limited liability were not the starting point[,] firms would create it by contract."). Tort creditors, however, generally lack an ex ante opportunity to negotiate.

52. A variant of this justification is that limited liability is worthwhile because it encourages people to take risks. Risk taking per se is not beneficial, however. It is warranted only if the risk taken is to engage in an activity whose expected social benefits, on the margin, outweigh its expected social costs. As discussed infra text accompanying notes 116-126, limited liability may encourage overinvestment in activities with excessive social costs.

53. Easterbrook \& Fischel, Limited Liability, supra note 6, at 94.

54. These analyses of limited liability appear to assume an alternative regime of unlimited joint and several liability. E.g., Easterbrook \& Fischel, Economic Structure, supra note 6, at 41-42 (arguing that limited liability reduces costs of monitoring other shareholders); see infra note 56 . 
ceivably lose an entire portfolio if any single investment went truly sour. If the investor were to properly manage the risk, she would have to acquire detailed information on corporate operations, potential corporate liability, and her potential individual exposure in the event of such liability. ${ }^{55}$ Obtaining the information could be pricey, ${ }^{56}$ as would be analyzing and acting on the information. ${ }^{57}$

Faced with the high monitoring costs associated with unlimited liability, the individual investor might simply forego the investment-even a worthwhile investment with positive net present value. As the argument goes, limited liability solves this problem by permitting the investor to manage risks by diversifying investments, rather than spending resources on monitoring. ${ }^{58}$

Efficiency justification advocates also argue that limited liability corrects excessive investor risk aversion. Under unlimited liability, a risk averse investor might suffer an additional cost "resulting from the uncertainty about whether a loss will occur." 59 The investor will avoid worthwhile investments or spend too much on risk avoidance because she will be averse to the risk of losing all of her assets, no matter how small the risk. ${ }^{60}$ The argument essentially is that the risk averse individual investor is a poor risk bearer. ${ }^{61}$ By reducing the shareholder's risks, a limited liability rule both reduces the cost of risk bearing to a shareholder and the

55. See Halpern et al., supra note 2, at 136 (noting that under unlimited liability, shareholders also must monitor each others' wealth).

56. Efficient market assumptions include perfect, costless information. Id. at 127.

57. Easterbrook \& Fischel, Limited Liability, supra note 6, at 94 (beyond a certain point "more monitoring is not worth the cost").

58. Similarly, because a shareholder's exposure under limited liability would not depend on the wealth held by other shareholders, limited liability reduces the informationgathering costs that would be entailed by the need to monitor other shareholders. Id. at 94. Easterbrook and Fischel describe the need to monitor wealth of other shareholders under a rule of joint unlimited liability. As others have noted, such costs also can be eliminated under a rule of pro rata liability. See Hansmann \& Kraakman, Unlimited Liability, supra note 2, at 1906; Leebron, supra note 2, at 1607-08.

59. Note, Liability of Parent Corporations for Hazardous Waste Cleanup and Damages, 99 Harv. L. Rev. 986, 995 (1986).

60. Easterbrook \& Fischel, Limited Liability, supra note 6, at 94.

61. Cf. Kenneth J. Arrow, Essays in the Theory of Risk-Bearing 136 (1971) (" $[\mathrm{I}] \mathrm{t}$ is profitable for all concerned that risks be shifted to the agency best able to bear them through its wealth and its ability to pool risk."). For example, suppose the corporate activity is to produce assembly-line machinery used by manufacturers. The manufacturerbuyer might be in a better position to bear the risk of the corporation's torts-negligent production of faulty machinery-than the owner of 100 shares of the corporation's stock. The buyer might invest less in bringing the risk to a manageable level, either by monitoring the corporation's activities, by examining the product, or by buying insurance, while the investor would continue to invest in the corporation and obtain utility from the investment. Overall, the sum of the manufacturer's utility and the investor's utility would be higher if the manufacturer bore the risk. This point is compellingly explained in Steven Shavell, Economic Analysis of Accident Law 189-92 (1987). 
cost of capital, and increases the availability of funds for "projects with positive net values." 62 By hypothesis, these are socially desirable projects.

These efficiency-based justifications, ${ }^{63}$ however, treat all corporate shareholders as pretty much indistinguishable. That is clearly not the case. Once variations in shareholder characteristics are considered, both efficiency-based justifications seem to have most persuasive power for the less wealthy individual shareholder holding a tiny fraction of corporate equity. The justifications are considerably weaker when the shareholder is a corporation or institution, is relatively wealthy, or is in a position to control the corporation.

\section{A. Parsing the Efficiency Justification}

Consider, first, the information costs justification. 1ts conclusion that limited liability enhances efficiency is based on the assumption that obtaining corporate operations information is costly for the shareholder.

For parent corporations and other shareholders with a significant ownership share, however, the assumption is highly questionable at best, and at worst, it is wrong. For these shareholders, information about the business is likely to be readily and cheaply available. ${ }^{64}$ For example, in State Department of Environmental Protection v. Ventron Corp., a parent company known as Velsicol incorporated a subsidiary, Wood Ridge, for the sole purpose of purchasing and continuing the operation of a mercury processing plant. ${ }^{65}$ The lawsuit concerned responsibility for the multimillion dollar cost of cleaning up the plant's extensive mercury contamination of a tidal estuary of the Hackensack River in New Jersey. ${ }^{66}$ The parent company had "constant involvement" with the subsidiary's day-today operations. ${ }^{67}$ Parent company employees were on the subsidiary's board of directors and attended monthly board meetings at which they monitored the minutiae of the subsidiary's business, including the details of the daily operations-"personnel practices, sales efforts, and produc-

62. Easterbrook \& Fischel, Economic Structure, supra note 6, at 44 . But see Presser, Piercing, supra note $16, \S 1.04$ ("[1]t is the quality of the investment opportunity itself, and not the elimination of possible personal liability that leads an investor to commit his or her capital.").

63. The following analysis takes as a given that efficiency is the criterion against which to measure limited liability's effects. Distributional consequences, although they are not a traditional focus of law and economics analyses, weigh against limited liability. The distributional concern is that individuals who benefit from corporate activity may be able to shift some of its costs to others who benefit little or not at all from the corporate activity.

64 . " $[\mathrm{T}]$ he parent as sole shareholder is almost invariably engaged in the managerial functions of establishing policy, determining budget, providing administrative support, and participating in the decisionmaking of the subsidiary corporation." Blumberg, Limited Liability, supra note 2, at 623 .

65. 468 A.2d 150, 155 (N.J. 1983).

66. See id. at 154 ("For a stretch of several thousand feet, the concentration of mercury . . . is the highest found in fresh water sediments in the world.").

67. ld. at 155. 
tion." 68 The parent faced no practical obstacles to acquiring information about environmental risk from the subsidiary's operations.

The assumption that shareholders face significant information costs is also dubious when the shareholder is another corporation or an institution. Even without occupying a position of potential or actual control in the corporation, an institutional shareholder's information costs are likely to be low. A corporation, bank, mutual fund, pension fund, or insurance company generally will be an able compiler and analyzer of corporate information. ${ }^{69}$

That leaves the individual shareholder with a small share of equity. Even for this shareholder, acquiring analyses of a company's performance and prospects, either from a market intermediary or on the Internet, may be straightforward. Furthermore, an expanded shareholder liability regime might lead small shareholders to more regularly demand the creation and dissemination of appropriately tailored analyses. Nonetheless, the assumption of significant information costs is most plausible for the individual shareholder with a small share of equity. Such a shareholder could find it difficult (or expensive) to acquire and effectively analyze detailed information about corporate operations.

Now consider the risk aversion correction justification. Preliminarily, of course, limited liability does not address investor risk aversion by reducing risks, but by shifting them. In the case of corporate tort and statutory liability, limited liability shifts these risks from shareholders to tort victims and the community at large. If the total social costs spent on managing risk are to be reduced, the new risk bearers must be better risk bearers than the shareholders. Generally, then, risk shifting will improve social welfare (measured as total social utility) only if two conditions are satisfied. ${ }^{70}$ First, the shareholder must not be better positioned to monitor or influence the risky corporate activity than the tort victim. ${ }^{71}$ If it

68. Id. at 155; see also Blumberg, Limited Liability, supra note 2, at 624 (“[F]ull information about the subsidiary's operations is always available to the parent corporation.").

69. Institutional investors also are likely to have ready access to information. See, e.g., Edward B. Rock, The Logic and (Uncertain) Significance of Institutional Shareholder Activism, 79 Geo. L.J. 445, 450 (1991) ("The heads of public employee pension funds have become high profile players in the corporate governance process. . . . At the same time, consultants have emerged who advise, encourage, and organize institutional investors."); Bernard S. Black, Shareholder Passivity Reexamined, 89 Mich. L. Rev. 520, 571 (1990) [hereinafter Black, Shareholder Passivity] (“[M]ajor public pension funds have gone beyond voting against management proposals, and are offering their own corporate governance proposals.").

70. The following analysis builds in significant part upon Steven Shavell's work. See generally Shavell, supra note 61 .

71. See id. at 175-76. Social welfare also will not be improved by the shifting of risk if the party that would have borne the risk could have procured insurance to spread it. See id. at $176 \mathrm{n.17}$ (arguing that to extent that shareholders could purchase liability insurance in absence of limited liability, "it is not clear that protection of risk-averse shareholders against risk should be considered an affirmative advantage of limited liability"). While 
were otherwise, risk shifting would create greater inefficiency by removing a monitoring incentive for the party that could most cheaply anticipate and avoid a loss. Second, the victim must be less risk averse than the individual shareholder, and thus more able or more willing to bear the risks ${ }^{72}$ associated with a particular corporate activity. ${ }^{73}$

The risk aversion correction justification does not apply equally to all varieties of shareholder. For many shareholders, as discussed below, both conditions are unlikely to be satisfied simultaneously. ${ }^{74}$ While the conditions are not assured of satisfaction even in this case, the justification has most persuasiveness when the shareholder is a less wealthy individual with a small share of the corporation's equity.

The first condition also focuses on information costs, but this time looks at their relative significance for different actors: Can the shareholder, compared with a tort victim, more easily (or cheaply) anticipate or avert injury from corporate activity? Assuming that the injury is the type that can be anticipated, most types of corporate shareholders will be better placed than tort victims to do so. Again, controlling and institutional shareholders will face relatively low information costs associated with monitoring their corporate investments. Suppose the firm's risky

some risks are difficult to insure, so-called "comprehensive general liability insurance" is a standard type of policy. See also Kenneth S. Abraham, Environmental Liability Insurance Law 24-25 (1991) (analyzing "Comprehensive General Liability" insurance). Moreover, environmental insurance has become increasingly available. See Marialuisa S. Gallozzi \& Alice V. Stevens, Transactional Uses of Environmental Risk Policies, in Practising Law Institute, New Solutions to Environmental Problems \& Real Estate Deals 301, 320 (2000) (noting that environmental insurance coverage limits have "increased steadily," while price has not "increased appreciably," and "available coverages continue to broaden"); Eric M. Jacobs, Emerging Issues in Pollution Insurance: Limiting Risk in the New Millennium, in ALI-ABA Course of Study, Environmental Insurance 319, 321 (2000) (noting increased capacity, reduced expense, and broadened coverage of current pollution insurance market).

72. Limited liability does not shift the entire risk of loss to the tort victim. See Shavell, supra note 61 , at $191 \mathrm{n.6}$ ("[1]t is never optimal for the entire losses [sic] to be shifted from one risk-averse party to a second."). For example, even under limited liability, shareholders bear some risk, in the sense that shareholders risk a decline in share value as a corporation pays a tort loss. Beyond that, the risk of loss is borne by the victim of the tort or statutory violation.

73. See, e.g., Cooper Alexander, supra note 11, at 390 ("Limited liability is said to produce a net gain to society because the rule shifts risk to better risk bearers."); Easterbrook \& Fischel, Economic Structure, supra note 6, at 45 (noting the argument that limited liability's benefits to shareholders will be exactly offset by detriment to creditors depends on questionable assumption that "risk is borne equally well by creditors and stockholders"). In the case of "involuntary" creditors, Easterbrook and Fischel do not attempt to argue that tort victims are less risk averse than individual shareholders, but instead argue that the question of whether limited liability should be retained for torts and statutory violations depends on an empirical analysis of the size of the moral hazard versus the benefits of retaining limited liability. Id. at 49-50.

74. If only one condition is satisfied, then limited liability's effect on efficiency is indeterminate. Whether the efficiency-enhancing effect will predominate over the efficiency-reducing effect is an empirical question. 
activity is manufacturing a risky product. Compared with an individual tort victim, controlling and institutional shareholders both can better monitor the extent of the firm's research into product risks and act on that information to influence the corporation to address the risks, whether the shareholders influence the corporation directly through corporate governance mechanisms or indirectly through the sale of shares.

The individual shareholder holding only a tiny fraction of equity in a large, publicly-traded corporation may face significant information costs. Consequently, she may be no better able than a potential tort victim to influence corporate activity directly. However, relative to a potential tort victim, such a shareholder still may have better access to corporate information, and, of course, she can sell her shares. For example, suppose the mercury processing plant in the Ventron case had had small individual shareholders. Those shareholders likely would have been better positioned than the downstream neighbors of the Wood Ridge processing plant to know that the plant was engaged in mercury processing and that it was discharging process waste into the river and thus to anticipate that the plant's operations were environmentally risky. ${ }^{75}$ In short, controlling, institutional, and even small individual shareholders under some circumstances, will be better than tort victims at anticipating and averting risks from corporate activities. ${ }^{76}$

Suppose that the risks presented by corporate activities could not possibly be anticipated. ${ }^{77}$ Shareholders would have no comparative advantage in monitoring or influencing corporate decisions. Even then, however, limited liability does not appear generally to satisfy the relative

75. Of course, in other cases, the individual shareholder's relative ability to anticipate risk may be less clear, such as where the tort victim purchases products with obvious risks. See infra note 76 .

76. This might not be the case for torts in which the tort victim has a long course of dealings with the corporation or for certain types of product purchases. For example, a small individual shareholder in a medical products company is not necessarily better able than a tort victim to anticipate that the company's manufacturing processes are resulting in leaky syringes. This may be especially true if the tort victim is an institution, such as a hospital. This might also be the case for a business tort, such as tortious interference with contract. However, the presence of some dealings between the tort victim and the firm (e.g., the purchase of a product) hardly means that the tort victim will be as able to anticipate the risks of the corporation's activities as the corporation and at least some of its shareholders. The vast majority of tort cases are brought by individual plaintiffs. See Bureau of Justice Statistics, U.S. Dep't of Justice, Bull., Tort Trials and Verdicts in Large Counties, 1996, at $3 \&$ tbl.3 (2000), available at http://www.ojp.usdoj.gov/bjs/pub/pdf/ ttvlc96.pdf (on file with the Columbia Law Review) (reviewing state court trials in seventyfive largest counties nationwide). Of product liability cases brought in 1996, approximately $70 \%$ involved asbestos or other toxic chemicals, defective medical products, and defective motor vehicles. Id. For these types of categories, concluding that an individual tort victim could better anticipate product risks than someone connected with the firm's operations seems difficult at best.

77. Cf. Alan Schwartz, Products Liability, Corporate Structure, and Bankruptcy: Toxic Substances and the Remote Risk Relationship, 14 J. Legal Stud. 689, 691 (1985) (discussing when risks are reasonably "knowable"). 
risk aversion condition-that shareholders are better risk bearers than tort victims. The answer to this question is more complex than the answer to whether most types of shareholders are better than tort victims in anticipating and averting risk. Nonetheless, for most combinations of shareholders and tort victims, there seems no persuasive reason to conclude that the tort victim would be consistently better at bearing risk than the shareholder.

Under a traditional economic analysis, the risk preferences of a tort victim will be a function of the type of injury from the tort (whether it is injury to property, person, or the environment) and the total costs of the tort imposed on the individual relative to the individual's wealth. ${ }^{78}$ This in turn will relate to whether there are others who would bear a portion of the loss, which would be a function of the type of tort as well as the liability rule. Whether others might bear a portion of the loss would also depend on whether insurance is available. For example, a potential tort victim might find health insurance to be readily available. For an injury to a shared environmental resource on which the individual relies (say, a body of water in which the individual fishes), finding insurance would be more difficult. Moreover, due to the substantial debates on how to value them, environmental injuries and severe health injuries (for example, death) do not fall neatly into such a framework. ${ }^{79}$

Similarly, for an individual shareholder, her risk aversion is a function of the proportion of her wealth that would be represented by the size of her loss from the injury. ${ }^{80}$ This in turn is a function of the loss attributable to the tort and whether there may be others that would bear a portion of the loss, which in turn depends on the liability rule and insurance

78. E.g., Shavell, supra note 61, at 189 ("The importance of risk aversion will ordinarily depend on the size of risk in relation to an individual's assets and to his needs. $\ldots$.. [W] here a person with assets of $\$ 300,000$ faces a $\$ 5,000$ risk, risk aversion will likely be an unimportant factor."). Of course, when a tort is suffered by multiple individuals or a community (as with a plane crash or an environmental injury), an individual's particular loss might be only a fraction of the loss for which the tortfeasor (say, a single shareholder) might be responsible.

79. The debate over the appropriateness of valuing human life is well-known and need not be discussed further here. See, e.g., W. Kip Viscusi, Strategic and Ethical lssues in the Valuation of Life, in Strategy and Choice 359, 359-61 (Richard J. Zeckhauser ed., 1991) (recounting the debate over methodological approaches for the valuation of human life). In the environmental context, there is an ongoing debate regarding whether the appropriate measure of social welfare should be a summation of individual preferences. See, e.g., David M. Driesen, The Societal Cost of Environmental Regulation: Beyond Administrative Cost-Benefit Analysis, 24 Ecology L.Q. 545, 579 (1997) ("It is not at all clear that public decisionmaking should reflect the aggregate of private preferences.").

80. See Shavell, supra note 61 , at 189 . An individual risk preference reflects that individual's marginal utility of income. For example, where the marginal utility of income to an individual is diminishing, the individual will prefer to avoid risks. See Lipsey et al., supra note 14 , at 165 n.7. Further, weal thy individuals, unlike presumably less wealthy tort victims, are generally in a better position to diversify risks. "Wealthy people and financial institutions are in a position to diversify, notwithstanding shareholder liability." Blumberg, Limited Liability, supra note 2, at 613. 
availability. A shareholder who stands to lose all her wealth likely will be more risk averse than one with only a small portion of her wealth at risk. ${ }^{81}$ Consequently, the greater an individual's wealth, the easier it is for her, as a general matter, to bear the risk of a given loss.

Take first the simplest case of risk shifting: a choice between whether a single tort victim will bear a financial loss that exceeds the corporation's assets or whether a single corporate or institutional shareholder will bear that loss. Generally, corporate and institutional shäreholders can be seen as risk neutral. ${ }^{82}$ For example, a parent company can spread the loss among its shareholders or fairly easily obtain liability insurance. ${ }^{83}$ Even the most conservative institutions, such as private pension funds, are not likely to be especially risk averse. ${ }^{84}$ Such investors are likely to have larger portfolios that can be diversified even in the absence of limited liability. Meanwhile, the wealthy person seems no more likely than anyone else to be a tort victim; tort victims generally are individu$\mathrm{als}^{85}$ and are likely to be randomly distributed by income. ${ }^{86}$

Thus, assuming that neither has an advantage in obtaining insurance, a tort victim is likely to be relatively more risk averse than such a corporate shareholder. ${ }^{87}$ Moreover, a tort victim's loss, even if expressed

81. See, e.g., Hansmann \& Kraakman, Unlimited Liability, supra note 2, at 1886 (noting that controlling shareholder of close corporation could be risk averse); Shavell, supra note 61, at 189 .

82. Institutional investors hold approximately half of the corporate equities in the United States. NYSE Facts 2000, supra note 12, at 61. Institutional investors other than mutual funds accounted for over $40 \%$ of the total holdings. Id.

83. See Hansmann \& Kraakman, Unlimited Liability, supra note 2, at 1882 n.6 (arguing that parent corporations are likely to be risk neutral); Note, supra note 59, at 995 ("[A]ny loss the parent might suffer would be spread widely among its shareholders and customers .... [Moreover, the parent] is in a good position to insure against the risk of [injury or liability].").

84. Even pension funds, which some might consider risk averse, are free, within Department of Labor rulings, to invest in securities issued by small or new companies and venture capital partnerships, provided they do not endanger an entire portfolio. Bd. of Governors of the Fed. Reserve Sys., Report to the Congress on the Availability of Credit to Small Businesses 44 (Oct. 1997) [hereinafter Bd. of Governors, Rep. to Congress], available at http://www.federalreserve.gov/boarddocs/rptcongress/sbc_rep.pdf (on file with the Columbia Law Review). Pension funds are increasing their investments in riskier businesses. Id. (noting that pension funds have become major investors in comparatively risky businesses through venture capital partnerships).

85. See supra note 76 (citing Bureau of Justice Statistics study).

86. Consequently, it cannot be easily assumed that tort victims as a group are risk neutral or risk preferring. The assumption that tort victims are likely to be randomly distributed by income seems conservative, given that environmental hazards, for example, tend to be concentrated in low income areas. Furtber, a wealtby individual could afford to take more risk-reducing actions, such as investing in more precautions (a safer car) or not purchasing a home near a major industrial facility. On the other band, greater wealth also might be related to risk-increasing actions, such as traveling to more places or buying more consumer products.

87. For simplicity, this analysis assumes that the victim of the potential corporate tort is a single individual. There is no reason to think that in cases of collective injury, such as 
in financial terms, may be something more significant or difficult to diversify, such as physical injury or death. ${ }^{88}$ Shifting risk in this case would reduce social utility. ${ }^{89}$

Assuming that the corporate or institutional shareholder can no less easily insure against the risk than the individual tort victim is clearly reasonable and even conservative. The assumption is appropriate, given the apparent availability of liability insurance to businesses ${ }^{90}$ compared, for example, with the significant number of individuals whose health is either uninsured or underinsured. ${ }^{91}$ Further, to the extent the shareholder possesses the capacity to control the corporation, the shareholder may be a better risk bearer because the shareholder can influence the corporation to buy insurance, thereby spreading risks. ${ }^{92}$

Even compared with the individual shareholder, a tort victim will not necessarily be a better risk bearer. Take the less wealthy individual shareholder (and again, assume an unforeseeable loss, so the shareholder's ability to monitor and influence the corporation is not relevant to the question). Assuming an equal ability to procure insurance, it is simply unclear whether such an individual shareholder will, on average, be a better risk bearer than the "average" individual tort victim.

Now assume that the individual shareholder is wealthy. Since tort victims are likely not to be especially wealthy, such a shareholder probably will be a better risk bearer than the victim. Finally, take the case in

environmental torts, a community either would be able to more readily predict and avoid the particular injury or would be less risk averse and thus better able to bear a particular risk than the tortfeasor. However, the analysis might change, for example, if each member of the community could be said to bear only a fraction of the injury. But see supra note 79 (noting theoretical debate on measures of environmental injury). Further, to the extent the victim of the potential corporate tort is another corporation, the corporation could be assumed to be risk neutral.

88. See Leebron, supra note 2, at 1602-03 \& n.116 ("tort injuries are in large part nondiversifiable and uninsured").

89. See Shavell, supra note 61 , at 207 ("In the case where victims are risk averse and injurers are risk neutral, it will be optimal . . . for injurers to bears the risk of victims' losses.").

90. Under an expanded shareholder liability rule, a shareholder's risks would be covered if either the shareholder purchased insurance or the corporation did. Liability insurance is generally available for "most businesses," even for environmental injuries. See Hansmann \& Kraakman, Unlimited Liability, supra note 2, at 1888 \& n.23; supra note 71 (finding environmental insurance increasingly available).

91. See Kenneth S. Abraham \& Lance Liebman, Private Insurance, Social Insurance, and Tort Reform: Toward a New Vision of Compensation for Illness and Injury, 93 Colum. L. Rev. 75, 80 (1993) (noting that "more than thirty million Americans have no private or socially provided health insurance, and about one-quarter of those who are covered by health insurance of some sort have inadequate coverage" (footnote omitted)). Moreover, even those individuals with first party insurance are unlikely to be fully insured for noneconomic losses, such as pain and suffering. See Leebron, supra note 2, at 1603.

92. Even if a particular corporate risk is completely unforeseeable, a corporation's purchase of insurance for foreseeable liabilities-say, comprehensive general liability insurance-still may help cover liabilities from an unforeseeable risk. 
which the shareholder has the capacity to control the corporation. Here, it is fair to conclude that the shareholder can more easily, through insurance, spread risks than the tort victim. Even if the shareholder herself cannot afford to or chooses not to purchase insurance, the shareholder can influence the company to buy insurance.

In short, it cannot be assumed, all else being equal, that a potential tort victim will be more risk neutral or risk preferring than the corporate shareholder, whether an individual or institution. In most instances, the stronger case is that the shareholder will be a better risk bearer.

Generalizations are even more difficult in complex cases, such as when both the victims of a single corporate tort and the shareholders that might bear excess liability are numerous. Tort victims certainly could be better risk bearers than shareholders if, for example, the class of potential tort victims was as numerous as the class of shareholders, but the tort victims generally were wealthier or were (presumably risk neutral) corporations or institutions. Tort victims also could be better risk bearers if a particular tort loss were shared among numerous victims, leading to a smaller potential loss per victim-and one that is significantly smaller than the potential per shareholder loss.

The data suggest, however, that tort victims are far less likely than shareholders to be corporations or institutions and, further, are likely to be less wealthy than shareholders. Moreover, we lack data suggesting that corporate tort victims will tend to be more numerous than the number of potential shareholders that might bear a loss in excess of corporate assets.

In short, the risk aversion correction justification (again assuming the simple case) argues that a shareholder will be less able than a tort victim to anticipate and influence risky corporate activity and will be a poorer risk bearer than a tort victim. Again assuming the simple case, this seems unlikely for the shareholder that is a corporation or institution. The strongest case for this conclusion involves the individual shareholder who is not particularly wealthy, ${ }^{93}$ who may have significant information costs, and for whom a loss may represent a substantial portion of her portfolio. For more complex cases, it is simply unclear whether shareholders are poorer risk bearers than tort victims.

It is fair to say, however, that both the information costs justification and risk aversion justification are relatively weak for the institutional shareholder and the shareholder with the capacity to control. They retain force primarily for a particular type of shareholder-an individual possessing only a small share of equity in a large corporation. For such a shareholder, information costs are relatively high, and the shareholder is not in a position to influence a corporation to insure or avoid risks. The

93. Cf. Blumberg, Limited Liability, supra note 2, at 576 (stating that most of limited liability's "theoretical advantages, however, are valid only when limited liability is interposed for the protection of the ultimate investors in the enterprise"). 
risk aversion story is less clear. ${ }^{94}$ However, to the extent the individual's portfolio would be threatened by a large corporate tort liability, the shareholder also may be risk averse. She may be more risk averse than the victim of a corporate tort, especially if the corporate tort victim is also one of a large class or has better insurance.

This is the shareholder, so the argument goes, who would forego a socially beneficial investment (i.e., one where the investment's social utility exceeds its social cost) either because monitoring costs are too high or because of aversion to a small risk of a significant corporate liability. For this shareholder, it might be socially "efficient" to have a less risk averse tort victim bear the costs of an unforeseeable risk. ${ }^{95}$

\section{B. Describing Shareholder Characteristics}

Sentimental notions aside, the reality is that the risk averse, small individual shareholder simply may not be "typical." There are many individuals whose only experience with shareholding consists of purchasing a few shares of a company traded on the New York Stock Exchange. Several pieces of evidence, however, suggest that most corporate shareholders do not fit the image of the "typical" small, less wealthy, risk averse shareholder facing significant information costs. Most shareholders look different.

First, most corporate equity is not held by individuals. Individual investors directly hold under $40 \%$ of corporate equity, and around $60 \%$ if mutual funds and pension funds are treated as individual investment. ${ }^{96}$

94. The information costs justification and risk aversion justification are in some tension with each other with regard to the proportion of ownership held by the shareholder. Take a class of shareholders, each of whom owns the same percentage of the corporation's stock. The information costs justification seems stronger the more numerous the class of shareholders (and thus the smaller likelihood each individual will cheaply obtain information and influence corporate operations decisions). Assuming that the limited liability alternative is a pro rata liability rule, the risk aversion justification seems stronger with a smaller shareholder class because, holding shareholder wealth constant, each shareholder will bear a larger proportion of total tort costs under the pro rata rule.

95. Perhaps needless to say, this analysis takes at face value the notion that maximizing total social utility should be the appropriate goal of these liability rules. Even if shifting risk from corporate shareholders to tort victims could be conceptualized as efficient, distributional concerns of course might weigh against such a shift. See supra note 63 .

96. Bd. of Governors of the Fed. Reserve Sys., Flow of Funds Accounts of the United States: Flows and Outstandings Fourth Quarter 2001, at 45 (2002) [hereinafter Flow of Funds 2001]. These statistics almost certainly overstate individual holdings of corporate equity, as the data on household holdings includes the holdings of nonprofit institutions and the equities data excludes intercorporate holdings. See New York Stock Exchange, Shareownership 2000, at 33 [bereinafter Shareownership 2000] (noting inclusion of nonprofit data), available at http://www.nyse.com/marketinfo/shareownersurvey.html (on file with the Columbia Law Review); Flow of Funds 2001, supra, at 45 (noting that data on corporate equities excludes intercorporate holdings). That statistic includes not only publicly-traded corporate equities, but estimates of closely-held shares (equity issued by 
The remainder is held by institutional investors, including other corporations. ${ }^{97}$ Moreover, institutional investors often hold a significant share of a given company's equity, ${ }^{98}$ improving their ability to monitor it. Institutional investors are more likely to be risk neutral than risk averse. Moreover, it is difficult to assume that institutional shareholders will tend to be more risk averse than tort victims, who are generally individuals. Institutional investors, including mutual funds, also can more easily obtain and analyze corporate information, placing them in a position to anticipate and potentially influence hazardous corporate activity. ${ }^{99}$

The individual shareholders of large, publicly-traded corporations listed on one of the three major stock exchanges (the NYSE, AMEX, or NASDAQ)-like the holder of 200 shares of General Electric-would seem most likely to conform to the image of the small, not especially wealthy, risk averse stockholder with no control over the corporation and with significant information costs.

However, directly-held individual equity holdings, as noted, are a minority of all corporate equity. And well over one-third of individual equity holdings, whether held directly or through the intermediary of a mutual fund, are not in publicly-traded equities. ${ }^{100} \ln 2000$, moreover,

private corporations, not puhlicly traded). Bd. of Governors of the Fed. Reserve Sys., Flow of Funds Accounts of the United States: Flows and Outstandings Third Quarter 1999 (2000) (discussing table L.213), available at http://www.federalreserve.gov/releases (on file with the Columbia Law Review). Mutual funds and pension funds, which own approximately $20 \%$ of all corporate equities, are considered institutional investors in these statistics. That seems appropriate in view of their superior access to corporate information and generally superior ability to diversify holdings. Even if mutual fund shares held by individuals were treated as "individually-held" corporate equity, and pension funds and other intermediaries were included as well, total individual holdings of U.S. corporate equity still would amount to something over $60 \%$ of the total equity. See Shareownership 2000 , supra, at 33 . Of the corporate equities held by mutual funds, a little over half of the investment in mutual funds is contributed by individuals; the remainder of the equity is held by institutional investors apart from mutual funds. See Inv. Co. Inst., Institutional Investors and Mutual Funds, Fundamentals, July-Aug. 1995, at 1 at http://www.ici.org/ economy/institutional_investors.html (on file with the Columbia Law Review) (citing 1994 figures).

97. Institutional investors hold $50.8 \%$ of all outstanding corporate equities. See NYSE Facts 2000, supra note 12, at 6. "At yearend 1989, the 50 largest institutions owned . . 27\% of the entire U.S. stock market. The 13 largest institutions held over half of this amountan average of over $1 \%$ of the U.S. market each." Black, Shareholder Passivity, supra note 69 , at $567-68$ (footnote omitted).

98. See Black, Shareholder Passivity, supra note 69, at 568 ("Legal obstacles notwithstanding, institutions are talking about, and occasionally moving toward, owning substantial stakes individually, or forming groups to hold such stakes.").

99. See supra note 96 .

100. An analysis of the 1998 Survey of Consumer Finance, a triennial survey conducted for a time by the University of Michigan Survey Research Center and currently by the University of Chicago National Opinion Research Center, see Arthur B. Kennickell et al., Family Finances in the U.S.: Recent Evidence from the Survey of Consumer Finances, 83 Fed. Res. Bull. I, 7-I1 (1997) (discussing survey methodology), indicates that a little over half of household corporate equity holdings consists of stock in publicly-traded 
household sector holdings of both publicly-traded and closely-held corporate equity totaled $\$ 7.3$ trillion and approximately $\$ 9.5$ trillion adjusting for mutual fund investments. ${ }^{101}$ By comparison, the total market capitalization of the New York Stock Exchange alone at that time was over $\$ 17$ trillion. ${ }^{102}$

We do not possess information enabling us to fully assess the risk preferences of individual shareholders. However, at least one characteristic of this group weighs against assuming that they are more risk averse than potential victims of corporate tort and statutory violations. The vast majority of corporate stock held by individuals is held by wealthy individuals. In 1998, shares on any of the major stock exchanges held by individual investors with total stock portfolios of $\$ 50,000$ or less accounted for less than $10 \%$ of all shares traded on any listed exchange owned by individuals. ${ }^{103}$ This includes shares held through mutual funds. Eighty-seven percent of shares held by individuals, either directly or through mutual funds, were held by individuals with stock portfolios exceeding $\$ 100,000.104$ This is not to say that an individual with a portfolio of $\$ 100,000$ in the stock market might not be risk averse-a retiree, for example, is likely to be quite risk averse, as may be someone evaluating an activity that would risk her entire portfolio. However, shifting a given risk only increases social utility when the shifting is to a person who is relatively less risk averse. The data on wealth does suggest that it is questionable to assume that these individuals should be presumed more risk averse for a given risk than a corporate tort victim, who cannot be presumed wealthy.

Assuming that individual investors are risk averse may be questionable for another reason: Just over $82 \%$ of households with investments in the stock market polled in a broad-based study sponsored by the Federal

corporations, held either directly or through mutual funds. The remainder constitutes equity in all types of privately-owned businesses. See Carol Bertaut \& Martha StarrMcCluer, Household Portfolios in the United States 26-27 (Fed. Reserve Bd. of Governors Working Paper, Apr. 2000) (finding that household stock holdings, either directly or through mutual funds, totaled $21.7 \%$ of household assets while "business equity" totaled $16.9 \%$; business equity figure includes both privately-held corporations and partnerships); see supra text accompanying note 12 (vast majority of business receipts attributable to corporations, compared with partnerships and sole proprietorships).

101. Flow of Funds 2001, supra note 96, at 90 tbls.L.213 \& L.214 (listing fourth quarter 2001 data); supra note 96 (discussing individual holdings of mutual funds). But see supra note 96 (arguing that mutual fund investments are more akin to institutional investments than individual investments).

102. See NYSE Facts 2000 , supra note 12 , at 5 .

103. Of 84 million individual investors holding common stock in 1998, approximately $60 \%$ had total stock portfolios of $\$ 50,000$ or less. Shares held by these investors accounted for approximately $6 \%$ of all shares owned by individuals. See Shareownership 2000, supra note 96 , at $15,27$.

104. ld. at 27 . This statistic probably underestimates these individuals' total wealth, since it does not take into account wealth other than holdings of common stock. 
Reserve Board ${ }^{105}$ viewed themselves as willing to tolerate an average, above average, or substantial amount of risk.106 (Thirty-five percent viewed themselves as tolerating an above average or substantial amount of risk.) 1t could be argued that these responses were made against the backdrop of limited liability and thus do not represent the levels of risk aversion that would be present in the absence of limited liability (and furthermore, survey results do not always reliably predict actual behavior). However, the survey results at least raise questions regarding whether an individual investor can be assumed to be more risk averse than an individual tort victim.

The composition of the shareholder population also raises questions about the information costs justification. As noted above, corporate and institutional shareholders, especially those in a position of control, such as parent corporations, are likely to face low information costs. ${ }^{107}$

Like the risk aversion justification, the information costs justification has greater force in the case of individual shareholders. However, even as to those shareholders, the story is not altogether clear. A substantial proportion of individual equity holdings are in close corporations, and share ownership in those corporations tends to be highly concentrated. ${ }^{108}$ The $\mathrm{S}$ Corporation shareholder generally is one of a very few. S Corporation returns represent approximately half of the 3.9 million corporation income tax returns filed with the 1RS, and somewhere between one-fifth and one-sixth of corporate economic activity. ${ }^{109}$ As discussed above, over $90 \%$ of S Corporations are owned by three or fewer shareholders. ${ }^{110}$ For close corporations generally, $79 \%$ have a shareholder with $50 \%$ or more of the equity. ${ }^{111}$ Small uninvolved shareholders are apparently relatively rare. "Relatively few small businesses raise equity from external sources." 12 The information costs justification would seem to have no

105. Id. at 8 (basing data on Survey of Consumer Finances; observing, "There is a broad consensus that the Survey of Consumer Finances provides the best available information on household asset holdings.").

106. Id. at 30 (analyzing University of Michigan's Survey Research Center data collected in 1998 Survey of Consumer Finances, on behalf of Federal Reserve Board).

107. See supra text accompanying notes $64-69$.

108. See supra note 100 (discussing individual shareholdings in close corporations); infra text accompanying notes 109-111.

109. Wittman \& Grant, supra note 41 , at 40. Not surprisingly, perhaps, S Corporations are a "small though growing percentage" of corporate net income. For Tax Year 1996, S Corporation income represented $17.6 \%$ of corporate net income. Id.

110. See supra note 43 . Less than $10 \%$ of $S$ Corporations had four or more shareholders. Ninety-nine percent had ten or fewer shareholders. Wittman \& Grant, supra note 41 , at 47 .

111. See supra note 44.

112. Bd. of Governors, Rep. to Congress, supra note 84 , at 41 . In this report, the Board of Governors commented that the definition of "small business" used by the Small Business Administration included firms with fewer than 500 employees. More than $99 \%$ of all businesses in the United States fit this definition. Id. at 1-2. Small businesses in high technology are a recent and notable exception, as such firms apparently do attempt to raise equity from external sources. Id. at 41 . 
application to these shareholders. An individual shareholder in a privately-held corporation very often will be in a position of actual or potential control. At a minimum, she can easily monitor the corporation, including the adequacy of its liability insurance.

ln short, shifting responsibility for foreseeable risks away from a shareholder in a small private corporation-who almost certainly will be better able than a potential tort victim to anticipate and influence corporate activity-seems likely to generate more inefficiency, not less. Even supposing the shareholder is risk averse because a liability loss could affect a substantial portion of the shareholder's portfolio, the net effect on efficiency of shifting the risk to a potential tort victim is indeterminate at best. ${ }^{113}$

For the case where a risk is genuinely unforeseeable and uninsurable, an individual shareholder with a large stake in a close corporation could be a poorer risk bearer than an individual tort victim, particularly if the tort victim is one of many. Again, however, it is difficult to assume that this will generally be the case. ${ }^{114}$

So what conclusions can be drawn from all of this? While many individuals do invest in corporate equity, a substantial portion of the market for both publicly-traded and privately-held corporate equity consists of investments from institutions and other corporations. They may possess the capacity to control, and even if not, their characteristics differ sharply from the profile of the "typical" less wealthy, risk averse investor with only limited access to corporate information. Further, a substantial number of individual investors in small corporations likely can easily monitor and exercise some influence over corporate operations. Meanwhile, limited liability is fully available not only to all small individual investors, but to these institutional investors, investment intermediaries, parent corporations, and controlling shareholders.

At a minimum, for these shareholders with characteristics divergent from those of the "typical" shareholders, limited liability seems overbroad and inefficient. Shifting the risks inherent in these investments to tort victims or victims of statutory violations does not increase social utility. For these shareholders, monitoring a corporation is cheap and easy. Relative to potential victims of corporate torts and statutory violations, they are far better placed to anticipate and influence potentially hazardous corporate activity. Finally, it cannot readily be concluded, especially as to institutional shareholders, that such shareholders will be more risk averse

113. See Shavell, supra note 61 , at 175-76 (arguing that such a shift would have a disadvantageous effect upon corporate incentives to control risk-creating behavior); supra text accompanying notes 70-73 (discussing conditions under which shifting liability risks will enhance efficiency).

114. See, e.g., supra text accompanying notes 105-106 (noting that most individual corporate investors considered themselves willing to tolerate "average" to "substantial" levels of risk); supra text accompanying notes 85-86 (regarding wealth of tort victims). 
than tort victims. Consequently, shifting the costs of excessively risky corporate behavior likely will not increase social utility, but will reduce it. ${ }^{115}$

\section{II1. Excessive Risk Taking Under Limited Liability}

Limited liability's moral hazard is the incentive created for corporations to engage in excessively risky activity, shifting the costs of this activity to tort and environmental victims. Much commentary has recognized the problem as a general matter. The following Sections outline the basic problem and provide some additional comments on evidence collected to date. These Sections also discuss the phenomenon of the corporation with a controlling shareholder. The corporate temptation to choose excessively risky activity will be especially pronounced when corporate equity is in the hands of a parent corporation or controlling shareholder.

\section{A. The Basic Moral Hazard Problem}

At least with respect to risky activities for which tort victims might seek to obtain legal recourse, limited liability presents an opportunity to avoid paying the appropriately-sized tort judgment. A corporation may be created or operated in a way that renders it "judgment-proof"- having only nominal assets available to pay a tort judgment. ${ }^{116}$ Or, a corporation simply may have inadequate assets available to fully cover its responsibility. ${ }^{117}$ And once the corporate assets are exhausted, the shareholder typically has no personal responsibility for the judgment except under quite limited circumstances-when the corporate veil can be pierced or when the shareholder's own conduct violates the law. ${ }^{18}$

115. Some might argue that the pervasive adoption of limited liability in the United States and other countries provides evidence of its efficiency. Certainly, limited liability cannot be lightly dismissed, and more empirical work would clarify the relative worth of the various shareholder liability rules. But legislative decisions to select limited liability would not seem to establish its credentials as the most efficient. For example, domestically, many other features of limited liability apart from efficiency might lead a state legislature to adopt it: uniformity with other state laws (limited liability is in the Model Business Corporation Act), or the legislative perception that the benefits of a business operating within the state will disproportionately benefit in-state residents, but that the costs will be spread among residents of many states. Finally, the interests of undercompensated tort plaintiffs likely are underrepresented in front of legislatures, not only because of free rider problems, see Mancur Olson, The Logic of Collective Action 9-16 (1980), but because of the simple difficulty of anticipating who will be affected by third party effects such as environmental injuries.

116. Corporate veil piercing rules imposing liability on a shareholder when a corporation has been undercapitalized provide little protection from this problem. See infra text accompanying notes 233-253.

117. See LoPucki, Death of Liability, supra note 29, at 46-47 (discussing "soft" judgment- proofing).

118. As discussed below, the opinion in United States $v$. Bestfoods has indicated that both such opportunities are very limited. 524 U.S. 51 (1998). See infra text accompanying notes 264-273. 
Consequently, corporate managers may select overly risky projects more often than is socially optimal. ${ }^{19}$ As a matter of economic theory, a shareholder will favor increases in risky activity as long as the anticipated marginal benefit to the shareholder from an increase in risky activity (for example, the present value of increase in expected dividends from corporate income) exceeds the anticipated marginal loss (present value of reduction in expected dividends or share price from costs of the activity, liability judgments, and the like), up until the point where the marginal benefit and marginal loss from an incremental increase in risky activity are equal. ${ }^{120}$ Under limited liability rules, the shareholder's total losses are capped at the value of the shareholder's potential lost equity. Thus, such risky projects may appeal to the shareholder even though they may be socially costly.

Further, as between two projects with equal benefit, each of which presents, say, a $10 \%$ risk of some liability that exceeds the corporation's assets, the shareholder will be indifferent between them, even though one might be more socially costly than the other. Suppose now the two projects are characterized by different potential benefits. Because the corporation will bear the project's costs only up to the amount of total corporate assets, rather than bearing full costs, the shareholder will prefer the project with a greater potential benefit, even if the net social benefit is smaller.

More generally, limited liability reduces the shareholder's incentive to gather and process information regarding a subsidiary's potentially hazardous activities, ${ }^{121}$ even when the shareholder is in a position of control or for other reasons can cheaply acquire that information. Consequently, even a risk averse shareholder may make fewer attempts to encourage management to obtain more insurance, take more precautions, or avoid the risky activity altogether. Thus the costs of excessively risky

119. See Easterbrook \& Fischel, Economic Structure, supra note 6, at 49-50 ("Because limited liability increases the probability that there will be insufficient assets to pay creditors' claims, shareholders of a firm reap all of the benefits of risky activities but do not bear all of the costs. These are borne in part by creditors."); Halpern et al., supra note 2 , at $143-45$ (" $[\mathrm{L}]$ imited liability could result in an incentive to firms to undertake excessively risky investment activities."); Stone, supra note 7, at 71 (describing how limited liability offers incentive for undercapitalized companies to engage in high risk projects).

120. This discussion assumes that the marginal benefit of a particular decision to shareholders and the firm's assessment of marginal benefit are identical. The marginal benefits and costs to the firm's managers can diverge, of course, from the marginal benefits and costs faced by the shareholder. A considerable literature discusses the problems shareholders have in ensuring that firm's managers serve the shareholder's interests. See, e.g., Easterbrook \& Fischel, Economic Structure, supra note 6, at 1 (presenting argument that managers are "able to keep investors in the dark," creating a "potential for misconduct"). As discussed below, however, any tendency by firm managers to select less risky opportunities than those favored by shareholders is not likely to offset fully the moral hazard of limited liability, especially when the shareholder is in a position of control. See infra text accompanying notes 254-255.

121. See Shavell, supra note 61 , at $175-76$. 
corporate decisions for which shareholders bear no responsibility (because corporate assets have been exhausted) are shifted to third parties, including tort victims, the environment, and the community, as well as other "involuntary creditors" to which the corporation is liable. ${ }^{122}$

This moral hazard has a number of consequences. The easy availability and effectiveness of limited liability in protecting the corporation's shareholders or parents will lead companies to select corporate restructuring as a means of managing the risk presented by hazardous corporate activities. ${ }^{123}$ Restructuring is essentially an investment in transaction costs.

Because corporations can limit liability by forming subsidiaries, the corporate tendency will be to divert investment from other, more efficient risk management strategies. For example, a corporation will be less likely to purchase adequate insurance or otherwise allocate risk through contracts. ${ }^{124}$ Further, a corporation may invest less in directly reducing the risks of its hazardous activities-say, by changing technologies or adding additional safeguards. ${ }^{125}$ With respect to environmentally hazardous activities, for example, because application of limited liability could be as, or more, effective in reducing potential environmental liability as investing in pollution-reducing technology, corporations whose managers

122. By comparison, contract creditors generally are in a better position to anticipate a risk of corporate nonpayment and to negotiate an expected payment that would compensate for the risk. See Halpern et al., supra note 2, at 128 ("The voluntary creditor will consider the probabilities that these outcomes will occur and determine an expected yield at which funds will be lent to the corporation to compensate for the risk."); see also id. at 135 (arguing that "for small companies with limited liability creditors often require personal guarantees [thus converting] the limited liability company into one with unlimited liability"); Easterbrook \& Fischel, Economic Structure, supra note 6, at 51-52 (showing that voluntary creditor can, ex ante, charge premium to compensate for risk); Jonathan M. Landers, A Unified Approach to Parent, Subsidiary, and Affiliate Questions in Bankruptcy, 42 U. Chi. L. Rev. 589, 623 (1975) (contending that creditors may have opportunity to protect themselves); Leebron, supra note 2, at 1601 ("Tort claimants differ from contract creditors in important ways.").

123. Given the wide array and effectiveness of devices that have traditionally been available for insulating the corporation from liabilities, corporate lawyers have been able to discharge their responsibilities by focusing principally upon insulating techniques for minimizing a corporation's exposure to environmental risks. See Peter Menell, Legal Advising on Corporate Structure in the New Era of Environmental Liability, 1990 Colum. Bus. L. Rev. 399, 402-03; see also Hansmann \& Kraakman, Unlimited Liability, supra note 2, at 1881 (noting that strong empirical evidence indicates that "increasing exposure to tort liability has led to the widespread reorganization of business firms to exploit limited liability to evade damage claims").

124. These latter methods are preferred ways of insulating the company from the effects of risk, since the risk bearers are likely to monitor the companies to minimize the possibilities of risk taking and encourage the company to take adequate precautions to avoid tort liability.

125. See Shavell, supra note 61, at 168 (arguing that incentive for injurer to take adequate care to avoid risk is significantly diluted if injurer can shield assets). 
decide to engage in environmentally risky activities often will direct their resources to creating a new corporate layer. ${ }^{126}$

For example, in one case, a company engaged in oil transport incorporated separate subsidiaries, each of which owned a number of barges that transported oil on Lake Champlain. The companies had identical officers and directors, and the subsidiaries remitted profits to the parent by way of dividends. The parent had substantial involvement in subsidiary operations. Poor barge operation led to a number of spills on Lake Champlain. The spills resulted from employees continuing to pump oil into the water after encountering a leak, employee failures to cap pipelines, and disregard of navigation agreements. ${ }^{127}$ The limited liability doctrine apparently encouraged resources to be devoted to corporate restructuring as a way to minimize environmental liability. Instead, the parent should have invested (or encouraged the subsidiary to invest) in training barge employees regarding appropriate measures to avoid oil spills.

\section{B. Preferred Risks Under Limited Liability}

The tendency toward excessive risk taking under limited liability will be skewed toward risky activities that present the risk of large losses. ${ }^{128}$ For example, suppose a parent company with a subsidiary owning $\$ 2$ million in assets compares a choice of two risky projects for the subsidiary. One presents a I\% risk of a $\$ 10$ million loss in the next year; the other presents a $25 \%$ risk of a $\$ 400,000$ loss in the next year. With unlimited liability for a parent corporation, and assuming that the corporation is risk neutral, these choices might well be evaluated equally: Expected loss would equal risk of loss times projected loss. With limited liability, however, the preferred project is clearly the first one-the small risk of a large loss-since the parent corporation will not bear the full costs in case

126. See supra note 123 .

127. These facts are taken from United States v. Ira S. Bushey \& Sons, Inc., 363 F. Supp. 110 (D. Vt. 1973). While the district court did agree to issue an injunction against the parent company, the case's decision, at the limits of veil piercing, seems somewhat atypical. Id. at 119. Although the parent company had observed proper corporate formalities, the court held that " $[t]$ he public interest in preserving the environmental integrity of Lake Champlain . . . is sufficiently paramount that the parent corporation, Bushey, which profits from the operations of its alter-ego subsidiaries, should be accountable." Id. More typically, the strategy of investing in multiple subsidiaries to manage risk succeeds. See, e.g., Walkovszky v. Carlton, 223 N.E.2d 6, 9-10 (N.Y. 1966) (refusing to pierce veil to shareholder in multiple subsidiary taxicab case).

128. See Hansmann \& Kraakman, Unlimited Liability, supra note 2, at 1883 (noting that small risk of large losses may encourage shareholders to overinvest in firm, assuming creating subsidiaries is easy). 
the gamble fails. ${ }^{129}$ The company is simultaneously less likely to purchase adequate insurance to cover the risk. ${ }^{130}$

As among excessively risky projects, corporations will be more inclined to select those with a relatively delayed realization of expected costs. Projects where the risky activity leads to a latent injury-one not immediately detectable, such as pollution or cancer-will be preferred. Projects with costs that cannot be imposed without a judgment in a court of law (e.g., common law tort litigation) will be preferred to projects with costs that can be imposed more quickly (say, through administrative fines). This is so even if the delayed costs have the same present value as if they were imposed today (if, for example, a court judgment rendered later were to include interest). If there is delay, a corporation and its shareholders can more easily separate corporate assets from the risky corporate activity. For example, the corporation is more likely to have sufficient time to distribute dividends to shareholders. Once the payments are made, a tort victim generally cannot gain access to those funds unless the corporate veil is pierced. ${ }^{131}$

While some have argued that tort victims may be indirectly protected from excessive corporate risk taking by contractual creditors that will insist on a showing that the corporation is maintaining adequate operating

129. Hansmann and Kraakman also discuss the possibility that a shareholder might underinvest in a particular firm engaged in risky activities. Limited liability results in the partial externalizing of the marginal increase in tort damages from expansion of the firm's risky activities. That generally would encourage a shareholder to overinvest in the firm. On the other hand, an increase in the value of the firm may make more assets available to pay damages to all tort claimants, which would discourage shareholder investment. As Hansmann and Kraakman acknowledge, however, the second effect is likely only when the risk facing the firm is a relatively large probability of damages that do not substantially exceed the firm's value. In other words, underinvestment is likely only when the marginal investment increases the probability that a firm will actually be fully responsible for its liabilities. Overinvestment in such firms is more likely when the activity presents a small risk of a large tort judgment and when it is easy for a firm to limit assets available for tort judgments hy creating subsidiaries. See id. at $1883 \&$ n.9.

130. Cf. Schwartz, supra note $\mathbf{7 7}$, at 709 (noting that a firm's incentives to insure against knowable risk dissipate when "its liability exposure greatly exceeds its wealth"). Schwartz also observes that the incentive to insure is reduced when the imposition of costs is delayed. Id. at 714-15 (arguing that when harms from a firm's action "do not materialize for several years . . . limited liability actually can create a pathological incentive for entrepreneurs to operate firms without full insurance and thereby to externalize risk"). While potential claimants also may have insurance for, say, medical expenses and property damage, see, e.g., White, supra note 50, at 1365 ("[v]ictims of random and conventional negligence are usually covered by insurance"), such policies may not cover extraordinary losses. Further, the firm (and its insurers) generally remain in a better position to anticipate and to avert potential injuries. See supra text accompanying notes 90-92 (regarding relative ability of tort victims to anticipate losses and procure insurance).

131. On rare occasions, a court will hear arguments from tort creditors to recover directly from shareholders on a fraudulent conveyance theory or if the corporation has been dissolved. See infra note 274-277 and accompanying text. 
reserves, ${ }^{132}$ the judgment values of tort suits still may greatly exceed available capital, leaving victims unprotected.

Tort judgment statistics suggest that the largest risks may involve defective products, toxic substances, and environmental injuries. ${ }^{133}$ In the case of environmental risks, the combination of "small risk/large loss" and "delayed cost realization" is typical. ${ }^{134}$ First, environmental losses tend to be delayed because the injuries to human health and the environment of particular substances may take years to manifest themselves. Second, once an environmental injury has occurred, cleaning it up or restoring the natural environment can be very expensive due to technological difficulty. ${ }^{135}$ Third, the process of enforcing environmental liabilitiesespecially large ones-is likely to take place years after the original conduct that created the environmental injury. Moreover, as a practical matter, legal action to address environmental harm faces significant obstacles. Lack of scientific knowledge often presents an obstacle to discovering environmental damage and to documenting such damage in court. ${ }^{136}$ Fourth, the probability of liability is reduced because environmental enforcement is predominantly pursued by federal, state, or mu-

132. See White, supra note 50, at 1396-99. But see Stephen L. Schwarcz, The lnherent 1rrationality of Judgment Proofing, 52 Stan. L. Rev. 1, 11 n.49 (1999) (noting that such protection may not reach tort claimants because "a company could compensate voluntary creditors without compensating involuntary creditors").

133. For example, in a survey of 1996 judgments in state court cases, plaintiffs in cases involving product liability claims or injury from toxic substances had, together with medical malpractice claims, the highest median awards of any tort cases. In over $10 \%$ of these cases, plaintiffs received awards of over $\$ 1$ million (combined compensatory and punitive damages). See Bureau of Justice Statistics, U.S. Dep't of Justice, Pub. No. NCJ 173426, Bull., Civil Trial Cases and Verdicts in Large Counties, 1996, at 7 (1999), availahle at http://www.ojp.usdoj.gov/bjs/pub/pdf/ctcvlc96.pdf (on file with the Columbia Law Review). By comparison, the median award in auto accident cases was $\$ 18,000$; only $3.4 \%$ of such cases involved awards of over $\$ 1$ million. Id. Environmental injuries also involve large potential liabilities. See infra notes 134-136 and accompanying text.

134. See Menell, supra note 123, at 404 n.20 ("Many environmental risks are remote, though of great potential magnitude.").

135. For example, over $80 \%$ of the approximately 1300 hazardous waste disposal sites on the Superfund National Priorities List involve groundwater contamination with hazardous substances. EPA, Groundwater Cleanup at Superfund Sites 1 (1996), available at http://www.epa.gov/superfund/tools/gw/brochure.htm (last visited Mar. 19, 2002) (on file with the Columbia Law Review). Groundwater extraction and treatment remedies run in the millions of dollars and "can take anywhere from several years to many decades," if it is feasible to clean up the groundwater at all. Id. at 3 . Generally, the Congressional Budget Office has estimated the average cost of cleaning up a National Priorities List site, including both capital investments and operations and maintenance (which can extend for decades), at over $\$ 20$ million per site, in present day dollars. Probst and others have estimated an average cleanup cost for National Priorities List sites of $\$ 29.1$ million and note that cleanup costs range widely by type of site, from $\$ 12.7$ million, on average, to clean up an asbestos site, to $\$ 170.4$ million, on average, to clean up a mining site. Katherine N. Probst et al., Footing the Bill for Superfund Cleanups 36, app. A, at 132 (1995).

136. See, e.g., Robert Percival et al., Environmental Regulation 4 (3d ed. 2000) (discussing uncertainty of mechanism and effect of environmental damage). 
nicipal government entities. ${ }^{137}$ Liabilities are frequently large, but many violations are not pursued. For example, in fiscal year 1997, the EPA obtained, on average, a penalty of over $\$ 700,000$ in Clean Water Act settlements, in addition to the costs of action to abate the violation, but the total number of such judicial settlements was only thirty-five. ${ }^{138}$ One estimate is that between $18 \%$ and $27 \%$ of "major" facilities holding such permits (a total of 7000 , at that time), were in significant noncompliance with their permits. In the hazardous waste context, as well, the EPA has taken enforcement action at only a fraction of the hazardous waste sites that warrant cleanup under its standards. ${ }^{139}$

137. Because environmental injuries so often involve shared resources such as water or air, private common law actions generally have been inadequate to address environmental harm. See, e.g., Frank P. Grad et al., Sen. Comm. on Env't and Pub. Works, serial No. 97-12, 1 Injuries and Damages from Hazardous Wastes-Analysis and Improvement of Legal Remedies 96-132 (1982) (discussing shortcomings of various common law actions for environmental harm). This was one reason for the enactment of the current array of state and environmental statutes, most of which are enforced primarily by governmental entities. See, e.g., Gwaltney of Smithfield, Ltd. v. Chesapeake Bay Found., 484 U.S. 49, 60-61 (1987) (holding that government has primary Clean Water Act enforcement responsibility, while citizen suits should serve supplementary role). A number of state and federal statutes do provide private rights of action, including citizen suits, but these often are available only to enforce prior government action or when the individual plaintiff already has made a significant financial investment. For example, the citizen suit provisions of the Clean Water Act authorize citizen suits against polluters only for violation of effluent standards or limitations under the chapter, or for violation of an order issued by the Administrator or a State. 33 U.S.C. $\$ 1365$ (a) (1994). Similarly, CERCLA's citizen suit provisions authorize suit against a polluter only if it is "alleged to be in violation of any standard, regulation, condition, requirement or order which has become effective pursuant to this chapter." 42 U.S.C. \$9659(a) (1994) (emphasis added). CERCLA's liability provisions authorize a private suit only to recover "necessary costs of response" to a hazardous substance release. 42 U.S.C. $\$ 9607$ (a)(4)(B) (1994). Consequently, environmental enforcement is still dominated by federal, state, or municipal action.

138. Office of Enforcement and Compliance Assurance, EPA, EPA-300-R-98-003, Enforcement and Compliance Assurance Accomplishments Report FY 1997, at AI-A2 (1998). Over the same period, the EPA noted that it reached administrative settlements for penalties in 205 cases of Clean Water Act violations (collecting a total of $\$ 4.2$ million), and issued 815 administrative compliance orders. 1d. There is perceived underenforcement of minor violations. See, e.g., Gen. Accounting Office, Letter Rep. GAO/RCED-96-23, Water Pollution: Many Violations Have Not Received Appropriate Enforcement Attention 2 (1996) (addressing violations of National Pollution Discharge Elimination System ("NPDES") permits); see also Gen. Accounting Office, GAO/RCED-91166, Environmental Enforcement: Penalties May Not Recover Economic Benefits Gained by Violators 1-2 (1991) (stating that EPA does not calculate a penalty that would prevent a violator from profiting from a violation). Generalized underenforcement alone could encourage regulated entities, including corporations, to take more minor risks. However, that does not dispel the point that limited liability also may encourage corporations to take major risks where liability, if imposed, would exceed corporate assets. Thus, strengthening enforcement to address minor violations as well as major violations would only partially address the problem. See, e.g., supra note 135 (discussing cost of groundwater cleanups).

139. The EPA has announced that, in addition to the 1300 sites on the National Priorities List where the EPA is pursuing hazardous waste cleanup and cost recovery from 
As noted, the presence of large liabilities is also likely to be marked in areas such as new product development, pharmaceuticals, and other areas presenting health and environmental risks. For example, the cost of damages from asbestosis alone amounted to $\$ 1.2$ billion by 1986 and is expected to exceed $\$ 31.7$ billion. ${ }^{140}$ Current cases involving the separation of treads on Firestone tires used on Ford Explorers are expected to exceed the hundreds of millions of dollars. ${ }^{141}$ Whether investment in corporate activities presenting these risks can be seen as "excessive" depends in part on whether the liability costs are likely to be paid. In some of the preceding examples, companies did pay liability costs. Nonetheless, the scale of these liabilities suggests that even large companies could take "excessive" risks (i.e., risks likely to be externalized).

\section{The Evidence of Excessive Risk Taking}

As a general matter, there is little disagreement that limited liability encourages companies to engage in excessively risky activity. Excessively risky activity could be defined as the activity generating externalized social costs-those not, as a practical matter, collectible through tort liability judgments. Since we lack the "control set" of an industrialized regime without limited liability, the extent of the overinvestment in this type of excessively risky activity remains an empirical question that is difficult to answer precisely. ${ }^{142}$

Some commentators have suggested that bankruptcy cases or unpaid tort judgments of corporate subsidiaries might prove to be an indicator of this excessive risk taking. ${ }^{143}$ However, even a systematic examination of reported cases in which tort or statutory plaintiffs attempted to obtain

responsible parties, there are between 1700 and 3000 "NPL-caliber" sites that meet the NPL-listing criteria of health and environmental threats that are not included in the federal remedial action program. See, e.g., Testimony of the Association of State and Territorial Solid Waste Management Officials: Hearing on H.R. 2500 Before the Subcomm. on Water Res. \& Env't, House Comm. on Transp. \& Infrastructure, 104th Cong. 1, 133 (1995) (statement of James Coleman) ("U.S. EPA and State Waste Managers project that there are potentially another $1700 \mathrm{NPL}$ caliber sites yet to be remediated in this country.").

140. Driesen, supra note 79 , at 596.

141. See, e.g., Chief of Bridgestone Says He Will Resign, N.Y. Times, Jan. 12, 2001, at W1 (noting Firestone parent company to take $\$ 750$ million charge against earnings in light of lawsuits). While total revenue figures for Firestone, the subsidiary that actually manufactured and marketed the tires, are hard to come by, at least one press release suggests that Firestone's net earnings may be significantly less than the liabilities expected by its parent. See Bridgestone Corporation Announces Decline in Consolidated Net Earnings and Sales Despite Strong Performance by Bridgestone/Firestone, Inc., at http:// www.bridgestone-firestone.com/news/corporate/news/17.html (last visited Aug. 29, 2000) (projecting total 1999 net earnings at $\$ 769$ million for Bridgestone and its subsidiaries) (on file with the Columbia Law Review).

142. See Easterbrook \& Fischel, Economic Structure, supra note 6, at 50; see also infra note 373 (discussing Weinstein's analysis of change in California from pro rata liability to limited liability).

143. See infra note 158 . 
compensation from corporations or their controlling shareholders likely would seriously underestimate the association of limited liability with excessive risk taking. This is because claims are very often resolved out of court prior to judgment. A large study of state court tort cases found that nearly three-fourths were resolved through settlement and the details of settlement generally were unknown. ${ }^{144}$ Moreover, claims frequently are resolved, explicitly or implicitly, in the shadow of limited liability rules and with the recognition that tort claimants do not fare well under bankruptcy rules.

Bankruptcy filings could be a more reliable indicator of excessive risk taking in mass tort cases, where the presence of large numbers of uncoordinated plaintiffs (or perhaps an overly aggressive plaintiffs' class action attorney) might lead some or all of the plaintiffs to litigate to judgment, with the combined weight of the suits forcing the company into bankruptcy.

However, in tort cases where there are only a few plaintiffs, the plaintiffs are well-coordinated, or the government is the plaintiff, bankruptcy filings would tend to underrepresent the size of the externality. ${ }^{145}$

Again, environmentally risky activity presents a good example. Here, corporations clearly rely on limited liability as a means of minimizing liability exposure, but not in a way that lends itself to systematic documentation. ${ }^{146}$ As noted, this type of activity can present the small risk of a large liability likely to be favored under a limited liability regime. The federal government, for example, brings large claims under the Comprehensive Environmental Response, Compensation, and Liability Act ${ }^{147}$ for cleaning up hazardous substance releases. Claims under this statute very often are in the millions of dollars, ${ }^{148}$ and the statute authorizes courts to im-

144. See Steven K. Smith et al., Bureau of Justice Statistics, U.S. Dep't of Justice, Special Report, Tort Cases in Large Counties, 1992, at 1-2 (reporting that of 378,000 tort cases in the nation's seventy-five largest counties, $73 \%$ of cases were resolved through agreed settlement, and noting that "details of tort settlements are unknown [; accordingly, v]ery few systematic data are available regarding why cases are settled or the cost of settlement for either party").

145. More information on the characteristics of tort litigation might help illuminate the usefulness of bankruptcy filings as an indicator of excessive risk taking.

146. Although the research is now somewhat outdated, Thompson notes that prior to 1986, arguments to pierce the corporate veil were made in only six environmental cases, and the veil was pierced in five of those cases. Robert B. Thompson, Piercing the Corporate Veil: An Empirical Study, 76 Cornell L. Rev, 1036, 1062 n.135 (1991) [hereinafter Thompson, Empirical Study]. Although he concluded that judges might be more likely to pierce the veil in environmental cases, he has since concluded based on later data that piercing in that category has a frequency "that [has] receded toward the mean of the entire sample." Robert B. Thompson, Piercing the Veil Within Corporate Groups: Corporate Shareholders as Mere 1nvestors, 13 Conn. J. Int'l L. 379, 385 \& n.35 (1999).

147. 42 U.S.C. $\$ \$ 9601-9675$ (1994 \& Supp. V 1999).

148. See, e.g., supra note 135 (discussing cost of groundwater cleanup). 
pose response costs on a wide array of entities with some connection to the hazardous substance release. ${ }^{149}$

If corporations used subsidiaries for environmentally risky activities, one might expect to observe a significant number of subsidiary bankruptcies in response to government enforcement. However, the vast majority of government claims are settled, very often for less than the face value of the claim. The government guidelines for settlement expressly internalize limited liability rules as the backdrop to settlement. For example, the EPA's settlement policies based on a defendant's "ability to pay" judge a company as "unable to pay" if paying would result in "undue financial hardship." 150 "Undue financial hardship" means that a company would go out of business, have its viability jeopardized, or lack the ability to pay "ordinary and necessary business expenses." ${ }^{151}$ In determining "ability to pay," the settlement policies assume that parent company assets are unreachable: "A corporation's owners (i.e., shareholders) generally enjoy limited liability for any of the corporation's debts or legal claims . . . . In assessing the financial health of a corporation, only the financial resources of the corporation are relevant." 152 Consequently, any count of the number of actual subsidiary bankruptcies in the face of large government environmental claims would substantially undercount the number of companies that have tried to limit exposure to environmental claims by moving their hazardous activities to a subsidiary.

The explicit government settlement policy for environmental claims simply codifies the more general calculation of a tort plaintiff that is considering settlement and attempting to determine expected returns from litigating. What a private plaintiff is likely to be able to obtain in court from a subsidiary also is constrained by current limited liability rules. Bankruptcy's high transaction costs and low priority for unsecured creditors will discourage invoking the bankruptcy court's protections. Thus, the general incentive for "tort victims suing under a regime of limited liability ... to accept a settlement for less than the full value of the firm"153 suggests that subsidiary bankruptcies in the face of tort or statu-

149. 42 U.S.C. $\$ 9607$ (a) (1994) (imposing liability on "owners," "operators," those that "arranged for disposal," or generators, and "transporters" of hazardous waste).

150. EPA General Policy on Superfund Ability to Pay Determinations 1, 2 (Sept. 30, 1997) [hereinafter EPA General Policy] (stating that party's "ability to pay" Superfund cleanup costs judged against "undue financial hardship" standard), available at http://es. epa.gov/oeca/osre/970930-4.html (on file with the Columbia Law Review); see also EPA Guidance on Determining a Violator's Ability to Pay a Civil Penalty 1 (Dec. 16, 1986) (noting that civil penalties can be adjusted for "extreme financial hardship"), available at http://es.epa.gov/oeca/ore/aed/comp/acomp/a1.html (on file with the Columbia Law Review).

151. EPA General Policy, supra note 150, at 2.

152. Id. at app.B. Assets of the corporation are deemed to exclude profits paid out to shareholders, although profits paid after notice of the environmental claim are viewed with considerably more suspicion.

153. Hansmann \& Kraakman, Unlimited Liability, supra note 2, at 1895 \& n.43 (arguing that tort victims will accept less than full value in order to avoid costs and delay of 
tory claims are likely to understate the extent to which corporations externalize the costs of risky activities. ${ }^{154}$

So what can be learned about the reality of excessive risk taking by corporations, especially corporations with a parent company or controlling shareholder? Several pieces of evidence suggest that such risk taking is significant and that incorporating represents a strategy to reduce liability flowing from the risk taking.

First, a plaintiff's attempt to pierce the corporate veil generally means that the plaintiff, at least, believes that the liable corporate entity lacks sufficient assets to compensate the plaintiff and that a major shareholder has significant additional assets. Otherwise, the plaintiff would have simply filed against the corporation alone and would not have spent the resources necessary to file a lawsuit against a shareholder. ${ }^{155}$ ln the 1970 s and 1980 s, approximately 1500 out of 2000 cases that mentioned veil piercing or a similar phrase actually consisted of attempts by plaintiffs to pierce the corporate veil. In Robert Thompson's study of these cases, as well as with the approximately 2100 veil piercing cases between 1985 and 1995, a little over half involved tort claims or claims of statutory violations. ${ }^{156}$

Second, anecdotal evidence regarding bankruptcies and claims against subsidiaries supports the claim of excessive risk taking. Again, on an aggregate level, the most relevant information might be the extent to which judgments against a corporation that arise out of tort or statutory claims exceed the assets available to a corporation, even though shareholders have significant assets. Judgments against a close corporation or a wholly- or largely-owned subsidiary would be of particular interest, since the shareholders more likely could have affected the corporation's ability to pay legal claims by influencing dividend distribution policy or other

obtaining litigated judgment). The presence of limited liability also may prompt an attorney to decline a potential lawsuit against the shareholder of a corporate tortfeasor, leading to further understating of the extent to which corporations externalize costs of risky activities.

154. The absence of observable data on settlements makes it difficult to conclude that limited liability is not accompanied by meaningful externalization of costs. See, e.g., Bainbridge, supra note 7 , at 500 (arguing that presence of mass corporate torts does not justify increased shareholder liability).

155. Of course, plaintiffs may try to pierce the corporate veil even when the underlying claim lacks merit. Further, a plaintiff's attorney conceivably might try to sue a parent company for strategic reasons-such as a better trial venue-even when the subsidiary is well-capitalized and capable of paying compensation. The cost of litigating and the difficulty of persuading a court to pierce the corporate veil likely will deter such activity. To the extent strategic suits against parent companies take place, however, the presence of reported veil piercing cases might overstate the extent to which corporations seek to externalize their costs through the creation of subsidiaries.

156. Thompson, Empirical Study, supra note 146, at 1048, 1058; Telephone Interview with Robert Thompson, Professor, Vanderbilt University Law School (May 14, 2001) (discussing unpublished research updates). 
operational decisions. ${ }^{157}$ As noted, such aggregate data is difficult to obtain and almost certainly understates the amount of excessive risk taking that takes place.

However, subsidiary bankruptcies do occur. ${ }^{158}$ Litigation over injuries from the Dalkon Shield and breast implants resulted in A.H. Robins and the Dow Corning Company, respectively, filing in bankruptcy. ${ }^{159}$ Further, in 1992, an involuntary bankruptcy petition was filed against Gulf USA Corp. for its inability to pay $\$ 70$ million in cleanup costs at a mining and smelting complex at Bunker Hill, Idaho. Gulf had been controlled by a series of individual shareholders that apparently had drained assets from its operations. ${ }^{160}$ After reorganization, the company paid less than $\$ 17$ million toward cleanup. ${ }^{161}$

Although no bankruptcy filing took place, the Exxon Valdez oil spill provides another example. Oil from that ship devastated Alaska's Prince William Sound. The tanker was owned by a subsidiary of the Exxon Corporation, the Exxon Shipping Corporation. Had Exxon claimed limited liability-which public embarrassment deterred it from doing-the subsidiary could not possibly have paid the cleanup costs. The parent company, however, had relatively little trouble covering the costs. ${ }^{162}$

In some ways, less visible examples are more telling. Although public pressure compelled Exxon to pay the judgment against the subsidiary that owned the tanker Exxon Valdez, public pressure may never come to bear in the cases of smaller business enterprises. For example, in State Department of Environmental Protection v. Ventron Corp. ${ }^{163}$ the parent com-

157. Other useful information might include the extent to which the creation of subsidiaries is more common in especially risky industries.

158. Bankruptcy filing data is suggestive of a broader corporate strategy to limit exposure to tort liability by forming subsidiaries, although drawing firm conclusions from bankruptcy filing data is extremely difficult. Compare White, supra note 50 , at 1379-80 (arguing that aggregate trend downward in dividends to creditors in bankruptcy is attributable to higher rate of personal bankruptcy filings), with LoPucki, Judgment Proofing, supra note 14, at 1419-20 (arguing that "only remaining explanation" for trend downward in dividends to unsecured creditors is that debtors could encumber more assets, leaving fewer for unsecured creditors).

159. See Cooper Alexander, supra note 11, at 424; supra text accompanying notes 295-302.

160. See And Forgive Us Our Trespasses, Forbes, May 24, 1993, at 42 (noting that Gulf's major shareholder at time of bankruptcy filing made "bondholders and shareholders [in his various companies] upwards of $\$ 400$ million” poorer).

161. News Briefs, Around the Valley and Idaho, Idaho Statesman, July 2, 1995, at 2B.

162. Apparently due to the high level of public indignation, Exxon "did not choose to contest its liability for the negligence of its subsidiary." Phillip I. Blumberg, The Increasing Recognition of Enterprise Principles in Determining Parent and Subsidiary Corporation Liabilities, 28 Conn. L. Rev. 295, 334 (1996) [hereinafter Blumberg, 1ncreasing Recognition]. Paying the liabilities associated with the spill injured, but did not disable, Exxon's finances. See Most Players in the Big Spill Have Moved On, Seattle Times, Mar. 20, 1994, at A16 (noting that Exxon Corp.'s usual net earnings of "about $\$ 5$ billion a year fell to $\$ 3.5$ billion the year of the spill, but rebounded in succeeding years").

163. 468 A.2d 150, 155 (N.J. 1983). 
pany, Velsicol, was not vicariously responsible for the contamination caused by a mercury processing plant owned by Velsicol's wholly-owned subsidiary, Wood Ridge. Wood Ridge was formed specifically for the purpose of operating the mercury processing plant. The plant had dumped mercury process waste into a tidal estuary of the Hackensack River in New Jersey, resulting in extraordinary contamination: "For a stretch of several thousand feet, the concentration of mercury . . . is the highest found in fresh water sediments in the world." 164 The parent company's involvement with the subsidiary's day-to-day operations was "constant," the subsidiary's board of directors were all officers of the parent, and the subsidiary's board reviewed not only finances and public relations, but also the details of daily operations such as personnel practices and production. Seven years after its incorporation, the subsidiary subdivided its forty acre parcel of land and declared a thirty-three acre land dividend-the land on which the factory did not sit and the subsidiary's major asset apart from the factory-to the parent. ${ }^{165}$ Nonetheless, the parent company did not voluntarily undertake responsibility for its subsidiary's liability and was not held vicariously liable because the subsidiary had not been created to "perpetrate a fraud or injustice."166 Cleanup costs are expected to be several million dollars. ${ }^{167}$

Further, in Craig v. Charter Consolidated P.L.C., ${ }^{168}$ the parent company, Charter Consolidated, P.L.C., an industrial and mining conglomerate incorporated in the United Kingdom that held $62.5 \%$ of a U.K. subsidiary known as Cape Industries, was held not responsible for its subsidiary's asbestos tort liability. Cape mined asbestos fiber in South Africa and sold it in the United States through a wholly-owned subsidiary. ${ }^{169}$ An individual injured as a result of his exposure to asbestos fibers brought suit against Charter, attempting to pierce the corporate veil and hold Charter responsible for Cape's stipulated personal injury liability.

\section{Id. at 154.}

165. Id. at 155 .

166. Id. at 164; see also State Dep't of Envtl. Prot. v. Arky's Auto Sales, 539 A.2d 1280, 1284 (N.J. Super. Ct. App. Div. 1988) (refusing to pierce corporate veil to two sole shareholders of site where drums full of hazardous contaminants were dumped, despite showing of extensive control). Although the parent company in Ventron eventually was held responsible for cleaning up the mercury contamination under a state statute, the N.J. Spill Compensation and Control Act, N.J. Stat. Ann. $§ \S 58: 10-23.11-.24$ (West 1992), such statutes now seem unlikely to provide a meaningful solution for the excess risk taking occasioned by limited liability. See infra text accompanying notes 264-273.

167. EPA, Ventron/Velsicol: NPL Site Narrative at Listing (1984), available at http:// www.epa.gov/superfund/sites/npl/nar149.htm (on file with the Columbia Law Review).

168. 843 F.2d 145 (3d Cir. 1988).

169. The parties to the case stipulated that corporate separateness between Cape and its wholly-owned subsidiary would be disregarded for purposes of the litigation, and that the veil piercing issue should be approached as though Cape had been found liable to plaintiff. See Craig v. Johns-Manville Corp., No. CIV.A.82-0321, 1987 WL 10191, at *2 (E.D. Pa. Apr. 23, 1987), rev'd, 843 F.2d 145 (3d Cir. 1988). 
Cape had engaged in a number of maneuvers to reduce its own liability to asbestos suits, including reorganizing to conduct business in the U.S. market through a new, "seemingly independent" corporation. ${ }^{170}$ Cape later made a policy decision not to appear in any United States asbestos litigation; over $\$ 78$ million in unpaid litigation judgments had been entered against it by the time the Craig case was tried. ${ }^{171}$ Meanwhile, evidence was presented in litigation that Charter, with nominees on Cape's board of directors, was generally aware of Cape's operational and financial decisions and was specifically aware of the decision of Cape (and Cape's subsidiary) to reduce warehouse inventory to "the lowest possible level" following Cape's loss in an asbestos personal injury suit. ${ }^{172}$

Charter took a majority share in Cape in 1969, after the first asbestos personal injury suits had been filed. ${ }^{173}$ Charter's purpose was to assure its control, so that Cape would serve as the "main channel for the expansion of Charter's industrial activities of the [building and light engineering] type."174 Charter had the authority to control the board of directors, its directors closely monitored Cape's finances, and a Charter statement suggested that it would "maintain ... close scrutiny of [Cape's] new capital expenditure projects." ${ }^{175}$ Among other things, Charter used its authority to make recommendations regarding Cape's dividend payments. Charter clearly could influence Cape's operational and financial decisions, probably including its decisions to take actions to minimize or avoid personal injury liability in United States courts. Nonetheless, the United States Court of Appeals for the Third Circuit declined to pierce the corporate veil and hold Charter responsible for Cape's liability for Craig's personal injury. ${ }^{176}$ These cases are anecdotal, but they illustrate that limited liability can result in corporations externalizing their costs and shifting them to tort victims.

Finally, corporations purposely rely upon limited liability devices as a strategy of minimizing liability risks. ${ }^{177}$ The fact patterns in cases such as United States v. Bestfoods, ${ }^{178}$ as well as in Craig and Ventron, suggest that

170. Id. at $* 9$.

171. Id. at $* 1$.

172. Id. at $* 8$ (quoting memo of Cape executive director Dr. R. Gaze).

173. See Bill Sanderson, Former Asbestos Factory Workers Sue Over Illnesses, The [Bergen] Record, June 10, 1987, at D1, available at Lexis, News Group File (mentioning $1950 \mathrm{~s}$ asbestos suit and $1960 \mathrm{~s}$ and $1970 \mathrm{~s}$ asbestos litigation; noting that "asbestos manufacturers have apparently known for decades that asbestos fibers are dangerous").

174. Craig, 1987 WL 10191, at *13 (quoting Charter share offer document) (alteration in original).

175. Id. at *15; Craig v. Charter Consol., 843 F.2d 145, 151-52 (5th Cir. 1998).

176. Craig v. Charter Consol., 843 F.2d at 152.

177. Because much corporate data, including tax returns, consolidates (at the election of the corporation) parent and subsidiary information, the most readily available information on this topic is anecdotal. See, e.g., White, supra note 50, at 1388 (noting that because of "consolidated data, reports on insurance and secured debt also fail to give any reliable information about the financial status of wholly owned subsidiaries").

178. 524 U.S. 51 (1998), discussed infra text accompanying notes 264-273. 
companies choose to create subsidiaries for the purpose of conducting risky activities, while minimizing the risk to parent company assets. ${ }^{179}$ Moreover, corporations contemplating entry into a risky industry are traditionally advised to create subsidiaries. ${ }^{180}$ While companies may not attempt to become completely judgment-proof, the creation of subsidiaries is a dominant strategy to reduce exposure to claims for environmental injury and other potentially large tort claims. ${ }^{181}$

A corporation attempting to insulate itself from liability by moving hazardous activity to a subsidiary probably will not seek complete "judgment-proofing." 182 Corporations certainly have legitimate reasons to use subsidiaries, including managerial and organizational efficiencies and the need to comply with foreign and domestic rules that implicitly or explicitly require separation of functions. ${ }^{183}$ Further, should a corporation form a subsidiary as a means of reducing corporate exposure to tort liability all the way to zero, such a subsidiary would be less likely to assure contract creditors of satisfaction, ${ }^{184}$ something necessary for the subsidiary to do ordinary business. Finally, the public would be more likely to view the subsidiary negatively.

However, the anecdotal evidence suggests that even if corporations do not seek complete judgment-proofing, they do use subsidiaries as a means of significantly reducing tort liability exposure. This seems especially likely for torts presenting some risk of a judgment substantially larger than, say, the size of contract debts that the subsidiary regularly

179. See State Dep't of Envtl. Prot. v. Ventron Corp., 468 A.2d 150, 155 (N.J. 1983) (creating Wood Ridge subsidiary to purchase and operate mercury processing plant); see also, e.g., Plaskon Elec. Materials, lnc. v. Allied-Signal, 1nc., 904 F. Supp. 644, 649 (N.D. Ohio 1995) (forming subsidiary "for the purposes of manufacturing semiconductor-related products and ' 446 ' polyester at the Site").

180. LoPucki, Judgment Proofing, supra note 14, at 1421; Menell, supra note 123, at 404 ("The principal risk-insulating strategy would be to set up the new production operation in a wholly-owned subsidiary corporation."); see Hansmann \& Kraakman, Unlimited Liability, supra note 2, at 1881.

181. E.g., Hansmann \& Kraakman,. Unlimited Liability, supra note 2, at 1881 \& nn.3-4 (noting efforts by tobacco and environmental services firms to use subsidiaries to evade tort liability); LoPucki, Death of Liability, supra note 29, at 21 ("This parentsubsidiary ownership strategy is in wide use among the largest companies in America.").

182. Lynn LoPucki has argued that in creating a subsidiary, a corporation's goal is to completely insulate itself from an adverse legal judgment. He contends that the creation of a subsidiary is a convenient "judgment-proof structure," because it can justify a transfer, to the parent, of excess earnings of the operating entity (as dividends), thereby making them unavailable to tort or statutory claimants. Lynn M. LoPucki, The Essential Structure of Judgment Proofing, 51 Stan. L. Rev. 147, 153 (1998).

183. See White, supra note 50, at 1389-90. White also notes that firms are highly unlikely to use subsidiaries to reduce their liability to zero in any event, because of public perception and the threat of veil piercing, among other things. ld. at 1399. But see supra text accompanying notes 163-167 (providing examples of subsidiaries having been used to deflect tort liability); infra text accompanying notes 233-253 (discussing veil piercing).

184. But see LoPucki, Judgment Proofing, supra note 14, at 1422-25 (noting that contract creditors commonly rely on assurances of repayment other than presence of unencumbered corporate assets). 
incurs. ${ }^{185}$ For these types of tort liability, the corporation can limit its exposure while simultaneously assuring contract creditors that corporate contractual debts are likely to be paid.

\section{The Special Case of the Controlling Shareholder}

Every corporation does not face an equivalent moral hazard from limited liability. Some have argued that a small, closely-held corporation may be more likely to select excessively risky activity than a big corporation, ${ }^{186}$ and that a wholly-owned subsidiary may face different incentives from a company owned by numerous individual corporate investors. ${ }^{187} \mathrm{~A}$ common thread unites these observations: Limited liability's moral hazard appears to be different for differently positioned shareholders. When a controlling shareholder, including a parent, is present, a corporation will be more likely to pick excessively risky, socially costly activity. When corporate ownership is dispersed, that tendency will be reduced.

This is likely for three reasons. First, when corporate ownership is dispersed, managerial risk aversion is likely to temper any shareholder tendency to take excessive risks. By comparison, a controlling shareholder can more easily compel managers to carry out its profit maximizing, risk taking preferences. Second, a controlling shareholder will be better able to strategically time dividend payments or equity sales to assure that the benefits from risky corporate activity are vested in shareholders before lawsuits are filed against the corporation. Finally, because a controlling shareholder obtains special benefits from corporate activities, such a shareholder will be more likely to encourage a corporation to take excessive risks.

To elaborate the first point, the well-documented phenomenon of managerial risk aversion will more likely blunt a tendency to select excessively risky activity. Limited liability's moral hazard is a temptation primarily for shareholders, not for managers. Limited liability subsidizes those costs from liability judgments that potentially exceed the corporation's assets. Unless constrained to do so by shareholders, bowever, managers are relatively unlikely to select corporate activities that present a risk of just these types of costs. They will be unwilling to select activities that amount to a bet-even a pretty good one-on the corporation's existence, because that also means betting their (undiversified) jobs. ${ }^{188}$ Man-

185. See, e.g., LoPucki, Death of Liability, supra note 29, at 46-47 (noting use of “[s] oft judgment proofing”).

186. E.g., Halpern et al., supra note 2, at 141 ("The moral hazard problem is likely to be more severe for small, tightly held companies than for larger companies.").

187. E.g., Blumberg, Limited Liability, supra note 2, at 630 ("If a subsidiary corporation constitutes only one of a number of components of a corporate group collectively conducting a fragmented unitary business, the very basis for the establishment of limited liability as a matter of general legal policy disappears." (internal citations omitted)).

188. See Easterbrook \& Fischel, Economic Structure, supra note 6, at 53 ("Human capital, for example, is notoriously difficult to diversify. Managers who have firm-specific 
agers will seek to avoid activities involving risks of devastating losses (destroying the corporate entity and their employment) even if the risk is remote, and even if selecting the activities might be to the benefit of the corporation's shareholders. ${ }^{189}$ Consequently, managers might not maximize profits in the strictest sense, which might involve selecting an activity whose downside costs could be subsidized by limited liability. Instead, managers might prefer to select corporate activities that achieve "target levels of profits," or other goals that will satisfy stockholders enough to keep managers' jobs, even if such an approach does not obtain every possible profit dollar for stockholders. ${ }^{190}$ Some have described this as operating at an "aspiration level"-one that protects managers from ouster, while avoiding high risks associated with activities for which a corporation may not be able to bear the full costs. ${ }^{191}$

When shareholders are numerous and dispersed, this managerial tendency could significantly offset excessive risk taking. Consider the small "passive" corporate shareholder, one of thousands of stockholders in a large corporation, who favors a level of corporate activity up until the point where expected marginal benefit to the shareholder is equal to expected marginal cost. The shareholder's calculation might well favor excessively risky activity, because, under limited liability, the shareholder will not fully bear the costs of such an activity. Agency costs, however, will prevent the shareholder from ensuring that managers fully maximize profits on the shareholder's behalf. ${ }^{192}$ Small shareholders will face this

investments of human capital cannot diversify the risk of business failure."); Merritt B. Fox, Insider Trading Deterrence Versus Managerial Incentives: A Unified Theory of Section 16(b), 92 Mich. L. Rev. 2088, 2097 (1994) ("A corporate manager, like anyone else, can be expected to value compensation, perquisites . . . and job security."); Zohar Goshen, Shareholder Dividend Options, 104 Yale L.J. 881, 887-88 \& n.32 (1995) (discussing managerial tendency to retain earnings to avoid business failure and potential loss of human capital).

189. See, e.g., George W. Dent, Jr., Toward Unifying Ownership and Control in the Public Corporation, 1989 Wis. L. Rev. 881, 889 ("Managers fear risk more than shareholders do because managers cannot diversify their investment of human capital as shareholders can diversify their investments of money."); Leebron, supra note 2, at 1606 n.124 ("Managers have human capital that is incapable of diversification invested in the firm. As a result, managers tend to be more risk averse than shareholders."); Roe, supra note 48 , at 542 ("[U]nconstrained managers often prefer to maximize the firm's size, to avoid severe but potentially profitable risks, and to defer hard, disruptive actions.").

190. See, e.g., John C. Coffee, Jr., Shareholders Versus Managers: The Strain in the Corporate Web, 85 Mich. L. Rev. 1, 29 (1986) (noting that managers seek "that level of profits that will suffice to prevent external interventions by dissatisfied creditors or stockholders"); Lipsey et al., supra note 14, at 320 (discussing "satisficing" behavior in firms).

191. See Schwarcz, supra note 132, at 26-27.

192. The presence of limited liability's distortion places us in the world of the "second-best." E.g., P.R.G. Layard \& A.A. Walters, Microeconomic Theory 181 (1978) ("If one of the standard efficiency conditions cannot be satisfied, the other efficiency conditions are no longer desirable."). Were there no other efficiency problems (e.g., no costs that a corporation could externalize), we might prefer that a shareholder be able to costlessly ensure that corporate managers fully maximize profits. Given the perverse 
agency problem for two reasons. First, the small shareholder is unlikely to have easy or inexpensive access to information necessary to evaluate managerial quality. A small shareholder interested in monitoring and participating in corporate management can face significant information gathering costs. ${ }^{193}$ Second, even if a small shareholder can acquire the information necessary to evaluate fully corporate management performance, influencing corporate management is difficult. Occasionally, takeovers and proxy fights can serve as avenues for groups of small shareholders to communicate preferences to corporate management or to ensure that they focus strictly on maximizing profits. ${ }^{194}$ However, small shareholders-especially those acting alone-generally are unlikely to participate significantly in month-to-month operations, or to know day-to-day operational details. ${ }^{195}$

When the corporation's ownership includes a controlling shareholder, however, the agency problem is reduced and the risk taking dynamic consequently is more pronounced. The controlling shareholder's agency costs are lower. The controlling shareholder generally has ready, low-cost access to information regarding operations or marketing plans. ${ }^{196}$ Depending on the jurisdiction, a parent corporation can, as part of normal operations, keep the books, approve the budgets, require that major capital expenditures be subject to approval, appoint the subsidiary's board of directors, ${ }^{197}$ and place its own employees in positions of

incentives created by limited liability, though, the argument here is that we prefer the existence of the second distortion-the agency costs associated with shareholder monitoring of managers-because it tends to offset the distortion from limited liability. Id. at 180 ("A first-best optimum is ruled out, and the problem is now to do the best we can, subject to the additional constraint.").

193. See Edward S. Herman, Corporate Control, Corporate Power 25 (1981); supra text accompanying notes 69-70 (discussing information costs faced by small shareholders).

194. But cf. Robert A. Ragazzo, Unifying the Law of Hostile Takeovers: Bridging the Unocal/Revlon Gap, 35 Ariz. L. Rev. 989, 1002 (1993) (noting that when control of a company with widely dispersed ownership is sold to one controlling shareholder, " $[t]$ he market for corporate control no longer acts as a check on management's decisionmaking").

195. See Herman, supra note 193, at 25 (“[T] he small, absolute and relative size of their holdings, their impersonal and distant relationship to the organization, and the high cost of obtaining detailed knowledge about a company and communication among numerous stockholders normally limit the cohesion and power of ordinary owners."). Of course, small shareholders still may have better information than potential tort victims. See supra text accompanying notes 74-76.

196. Herman, supra note 193, at 25 ("These investors are knowledgeable, in close communication with one another, and interested in corporate affairs because of the size of their holdings."); Loftus C. Carson, II, The Liability of Controlling Persons Under the Federal Securities Acts, 72 Notre Dame L. Rev. 263, 317-18 (1997) ("[C]ontrolling shareholders may confer with directors and executive officers about a range of corporate matters from the selection of officers to various corporate policy and operational matters.").

197. Committee on Corporate Laws, Guidelines for the Unaffiliated Director of the Controlled Corporation, 44 Bus. Law. 211, 212 (1988) [hereinafter CCL, Guidelines] (“In 
control at the subsidiary. ${ }^{198}$ Further, managers obviously will respond more readily to a controlling shareholder's concerns than those of a shareholder with a small ownership stake. ${ }^{199}$

Thus, the controlling shareholder can more easily detect managerial risk aversion and can strongly encourage or even compel managers to select the most profitable opportunities. Such opportunities may include those that appear profitable, only after taking into account limited liability's subsidy of liability exposure.

Further, where the controlling shareholder is a parent corporation, the shareholder may be able to address managerial risk aversion in other ways. For example, the parent may be able to find a position for a loyal, displaced manager who was the victim of an ultimately realized small risk. This possibility may comfort the manager who is considering whether to select an excessively risky corporate activity. 200

ln addition to overcoming the effect of managerial risk aversion, controlling shareholders will be better able than small shareholders to ensure that they preserve their gains from the corporation's risky activi-

a controlled corporation, all of the directors (including the unaffiliated directors) are usually voted into office with the support of the controlling shareholder.").

198. See United States v. Bestfoods, 524 U.S. 51, 69 (1998). Majority shareholders of an enterprise have "authority to ratify and monitor with regard to certain organizational personnel and affairs because they have the legal right to select and remove directors and to veto significant proposed corporate changes of a structural nature." Carson, supra note 196, at 281-82 (footnotes omitted). A parent company can retain substantial control and the other incidents of ownership and possesses considerable access to information regarding the company's operation. See, e.g., Rev. Model Bus. Corp. Act $\S 11.01$ (a) (1984) (requiring shareholder approval for mergers); id. $\$ 12.02$ (a) (conditioning corporation's sale of all or substantially all its assets on shareholder approval); Del. Code Ann. tit. 8, $\$ 275$ (b) (2001) ("If a majority of the outstanding stock of the corporation entitled to vote thereon shall vote for [a] proposed dissolution, a certificate of dissolution shall be filed with the Secretary of State."); see also Anderson v. Abbott, 321 U.S. 349, 357 (1944) (holding that owner of banking stock cannot escape liability by transferring shares to holding company, "[f] or he retains control and the other benefits of ownership without substituting in his stead any one who is responsible for the risks of the banking business").

199. See Carson, supra note 196, at 316-17 ("[C]ontrolling shareholders have the power to select the board and they can and frequently do exert pressure on directorial decision making that may be dispositive."); see also Principles of Corporate Governance: Analysis and Recommendations $\$ 1.10 \mathrm{cmt}$. (1994) [hereinafter Principles] (defining as a controlling shareholder any person who exercises control by virtue of position as a shareholder).

200. Some might argue that even when share ownership is dispersed, managerial risk aversion could be curbed effectively simply by providing stock options to managers. Stock options may encourage a manager to take greater risks, as the manager has the option to share in the corporate activity's gains while avoiding its losses. However, they seem unlikely to offer any compensation for corporate activities that present a risk of bankruptcy and consequently the loss of the manager's firm-specific investments in human capital. Harold Demsetz and Belen Villalonga have recently presented the results of an empirical investigation treating both ownership structure and firm performance as endogenous variables; they observe that firm-specific risk (an exogenous variable) was not significantly affected by the fraction of ownership shares held by management. Demsetz \& Villalonga, supra note 47 , at 20 . 
ties. A corporation's parent could, for example, compel the corporation to pay dividends promptly when the corporation is engaged in very risky activities. The parent also might simply sell the subsidiary. This might mean that the parent (as well as other shareholders) could lock in benefits from those activities before a tort or statutory claimant threatens or files a lawsuit, or, in some instances-such as with activities involving health or environmental risks-before the risky activity has even created known social costs. The parent thereby redistributes corporate income to itself and away from the victims of corporate torts and statutory violations.

LoPucki describes a generalized version of this phenomenon as separating the corporation's risky business from the corporation's assetseven those generated by the risky business itself. ${ }^{201}$ The subsidiary can be capitalized appropriately, but after its initial creation, the parent can strongly encourage the subsidiary to distribute the proceeds of its business, beyond its immediate cash needs, as dividends. Once distributed to the parent, these dividends generally cannot be reached based on a subsidiary's tort or statutory violation unless the corporate veil is pierced. ${ }^{202}$

Dividend-paying behavior of this type is not unusual. ${ }^{203}$ For example, in the Ventron case, after a corporate subsidiary had operated a mercury processing plant for several years, the parent corporation took possession of thirty-three of the subsidiary's forty acres as a "land dividend," leaving the subsidiary in possession only of the seven acres on which the plant itself stood and limiting the subsidiary's ability to pay tort judgments based on nearby mercury contamination. ${ }^{204}$ Further, in the famous case of Walkovszky $v$. Carlton, the sole shareholder of several taxicab corporations arranged for constant dividend payments, thereby limiting the corporations' ability to pay tort judgments. ${ }^{205}$

Finally, a controlling shareholder can obtain special benefits from corporate activity. As a result, the controlling shareholder likely will prefer a risky corporate activity even when a shareholder without control

201. LoPucki, Judgment Proofing, supra note 14, at 1414.

202. Unless a shareholder has (or should have) knowledge of a likely lawsuit, fraudulent conveyance law generally will not preclude this type of transfer. Knowledge that the corporation is selecting risky activity is not likely to suffice. See infra text accompanying notes 274-277. When shareholders elect to dissolve a corporation, they may be responsible for corporate debts for a limited period of time after the corporation's dissolution. Id.

203. Small shareholders generally will not be able to use a lawsuit to compel corporate dividend payments. In general, the decision of corporate managers to pay or not to pay dividends is reviewable under the highly deferential business judgment rule. See, e.g., Sinclair Oil v. Levien, 280 A.2d 717, 720 (Del. 1971) (holding that business judgment rule requires court not to disturb decision of board of directors "unless there is a showing of gross and palpable overreaching," or unless "fiduciary duty is accompanied by self-dealing").

204. State Dep't of Envtl. Prot. v. Ventron Corp., 468 A.2d 150, 155 (N.J. 1983).

205. 223 N.E.2d 6, 11 (N.Y. 1966). 
would not favor such an activity, because the marginal benefit from the corporate activity to the controlling shareholder will be higher. ${ }^{206}$

A controlling shareholder's share of benefits from corporate activity is likely to exceed the shareholder's pro rata share of corporate equity. A $70 \%$ shareholder will have, as a practical matter, $100 \%$ authority to control corporate activity, while the $0.1 \%$ shareholder will possess a minuscule or zero ability to influence corporate activity. The extra increment of control carries value with it. The intuition that control represents tangible value to the shareholder that possesses it is strongly supported by the size of premiums normally paid for controlling shares. Purchasers of controlling shares very often pay a premium per share acquired of $30 \%$ to $40 \%$ above the market price for the share. ${ }^{207}$ ln the 1980 s, takeover premiums averaged $50 \%$ over market. ${ }^{208}$ Although measuring premium size in privately-held companies is more difficult due to the lack of a public market for minority shares, buyers typically pay control premiums for controlling shares in these companies as well. ${ }^{209}$

206. The accentuated tendency to take excessive risks could be offset if a controlling shareholder is more risk averse than noncontrolling shareholders-for example, if the shareholder had invested most or all of its assets in a single business enterprise. As discussed above, however, a controlling shareholder can prompt a corporation to pay dividends, which can reduce the assets a controlling shareholder will have at risk in the corporation's business. Further, controlling shareholders very often will be corporations or other institutions. For those entities, there seems to be no reason to conclude that risk aversion will be typical. For the individual controlling shareholder with the bulk of her assets invested in a company, however, the shareholder could well be risk averse, and that would clearly reduce any tendency to encourage the corporation to take excessive risks.

207. As noted, controlling shares are typically purchased at a significant premium. For example, cash tender offers made in 1977 for a controlling share included an average cash premium of $32 \%$ above the market price. Michael Maher, An Objective Measure for a Discount for a Minority Interest and a Premium for a Controlling Interest, 57 Taxes 449, 454 (1979). More recently, premiums have ranged well over $40 \%$ and as high as $100 \%$ in tender offers, such as 1BM's 1995 purchase of the Lotus Development Corporation and Vivendi's 2000 purchase of the Seagram Company. E.g., Judith H. Dobrzynski, The Art of the Hostile Deal, N.Y. Times, June 22, 1995, at D1 (discussing sale of Lotus to IBM in which control premium was over $100 \%$ ); Geraldine Fabrikant \& Andrew Sorkin, French Company Agrees to a Deal to Buy Seagram, N.Y. Times, June 20, 2000, at A1 (noting that $44 \%$ premium was paid). Two-thirds of acquisitions with known control premiums involved a control premium of over 25\%. See The Fastest Lane in the Deals Market, Mergers \& Acquisitions, Mar.-Apr. 1999, at 23-24 (reporting 1998 data showing that of tender offers whose control premiums were known, two-thirds of such premiums ranged from $25 \%$ to $95 \%$ over target's stock price); see also Stuart Elliott, The $\$ 1.9$ Billion Saatchi Deal Vaults Publicis to the Top Tier, N.Y. Times, June 21, 2000, at C6 (reporting Publicis S.A.'s purchase of Saatchi \& Saatchi at premium of over $50 \%$ ); Seth Schiesel, Web Hardware Maker Buys Digital 'Plumber' for $\$ 41$ Billion, N.Y. Times, July 11, 2000, at Cl (reporting JDS Uniphase Corp.'s purchase of SDL Inc. at "takeover premium of almost 50 percent").

208. Ragazzo, supra note 194, at 1012.

209. Telephone Interview with Bruce A. Gutenplan, Partner, Paul, Weiss, Rifkind, Wharton \& Garrison (Sept. 28, 2000); see, e.g., Montgomery v. Aetna Plywood, Inc., 39 F. Supp. 2d 915, 934 (N.D. Ill. 1998) (calculating control premium for sale of interest in privately-held corporation). 
This Article will not attempt a detailed analysis of the precise manner in which a controlling shareholder realizes the benefits of control. ${ }^{210}$ However, even briefly explained, it seems clear that a shareholder's possession of corporate control confers tangible and unique benefits on the shareholder.

A major reason for acquiring control, of course, is the ability to realize greater profits by improving or changing the corporation's management. Minority shareholders may also benefit from this, since better management can be reflected in increased dividends, which are paid pro rata. ${ }^{211}$ However, a controlling shareholder also can obtain benefits not shared with minority shareholders.

First, a controlling shareholder can benefit from synergies between the corporation and the shareholder's other businesses. ${ }^{212}$ For example, Ford Motor Company's ownership of Volvo, Mazda, and other car manu-

210. Some have argued that control buyers overpay for control. See generally Bernard S. Black, Bidder Overpayment in Takeovers, 41 Stan. L. Rev. 597 (1989) [hereinafter Black, Bidder Overpayment] (arguing that control buyer overpayment partly explains patterns of shareholder gains after takeovers). However, it is hard to imagine that overpayment accounts systematically for the presence of the control premium. Further, Stephen Choi and Eric Talley have argued recently that block shareholders can obtain a variety of special benefits, including not only the synergy opportunities and tax advantages described below, but also selective information disclosure. See Stephen J. Choi \& Eric L. Talley, Playing Favorites With Shareholders, 75 S. Cal. L. Rev. 271, 284-310 (2002).

211. A controlling shareholder may be willing to pay some premium per share for the possession of control in order to improve corporate profits, and hence the payment of dividends, even if minority shareholders benefit equally from the increased dividends payable per share. The controlling shareholder may find the prospect of improving management so attractive that it is willing to tolerate some free riding by minority shareholders. Cf. Steven P. Croley, Theories of Regulation: Incorporating the Administrative Process, 98 Colum. L. Rev. 1, 19-21 (1998) (arguing that individuals join in collective action despite free rider problem because of nonmaterial advantages such as moral motivation, solidarity values, and political entrepreneurship). This phenomenon may be reflected in the observed increase in the value of minority shares in a company that is the target of an acquisition. See Karen Hopper Wruck, Equity Ownership Concentration and Firm Value: Evidence from Private Equity Financings, 23 J. Fin. Econ. 3, 12 (1989) (observing that presence of controlling shareholder tends to increase firm's value because of better management); Randall Morck et al., Management Ownership and Market Valuation: An Empirical Analysis, 20 J. Fin. Econ. 293, 306 (1988) (noting that firms with significant percentage of equity held by board member have higher profits). However, the continuing presence of a substantial difference between the per share price of a minority share and the per share price of a controlling share strongly suggests that the prospect of improving management in a way that would benefit each shareholder pro rata explains only some of the value a controlling shareholder expects to receive upon acquiring control.

212. See Black, Bidder Overpayment, supra note 210, at 608 (describing possible synergistic effects of merger created by economies of scale, improved management of target, and more efficient use of human resources and capital); John C. Coates, IV, "Fair Value" As an Avoidable Rule of Corporate Law: Minority Discounts in Conflict Transactions, 147 U. Pa. L. Rev. 1251, 1275 (1999) (“[s]ynergies can arise on the input and output sides of a firm"); Telephone Interview with Sam Frieder, Principal, Kohlberg \& Company (Sept. 22, 2000). 
facturing entities presumably allows economies of scale in automobile design and manufacturing, and improved bargaining leverage in the purchasing of parts from suppliers. The shareholder may benefit not only as a result of investing in the acquired business, but the shareholder's other businesses -in which minority shareholders likely have not invested-also may be more profitable as a result.

Second, possession of the controlling share may provide the shareholder with an opportunity for, using the terms loosely, self-dealing or expropriation. ${ }^{213}$ For example, suppose Ford exercised its control as a majority shareholder in Hertz to require it to buy Ford cars. Ford, but not the minority shareholders in Hertz, could capture the seller's surplus from such transactions. While this type of self-dealing is constrained by the shareholder's fiduciary duty to minority shareholders, a controlling shareholder nonetheless will have some legal latitude to influence the corporation to select actions that will benefit the controlling shareholder more while benefiting minority shareholders less. ${ }^{214}$ Consider Sinclair Oil Corp. v. Levien. ${ }^{215}$ There, a $97 \%$ parent corporation systematically arranged for the payment of corporate dividends that exceeded, by $30 \%$, the corporation's earnings over the same time period, apparently because the parent corporation was short of cash. ${ }^{216}$ Although they received their pro rata share of dividends, the minority shareholders viewed these dividend payments as against their interest because they prevented the corporation from making capital investments that would improve its value over the long term. ${ }^{217}$ Nonetheless, in the face of a legal challenge by minority shareholders, the Delaware Supreme Court upheld the dividend

213. True "self-dealing," such as the outright expropriation of corporate assets for private purposes, could, of course, expose the shareholder to liability for violating a fiduciary duty to minority shareholders.

214. E.g., CCL, Guidelines, supra note 197, at 212 (stating that controlling shareholders might permissibly seek to cause corporation to contract with controlling shareholder, try to eliminate noncontrolling shares through "cash-out merger," or cause controlled corporation to repurchase shares from controlling shareholder); Coates, supra note 212, at 1275-76 (stating that expropriation value includes "excessive retention of assets; excessive distributions; payment of above-market, but not clearly excessive, amounts for goods or services; or freezeouts priced to take advantage of a 'blockage' of non-material information" (footnotes omitted)); see also Deborah A. DeMott, Down the Rabbit-Hole and Into the Nineties: Issues of Accountability in the Wake of Eighties-Style Transactions in Control, 61 Geo. Wash. L. Rev. 1130, 1137 (1993) (describing minority shareholder action against controlling shareholder for alleged self-dealing in violation of fiduciary duty).

215. 280 A.2d 717, 721 (Del. 1971).

216. Id. at $719,720-21$.

217. Needless to say, perhaps, the assumption here is that two shareholders may not have the same view of the utility of an equivalent dollar payout in dividends. This is because opportunity costs may differ by individual. Even if one shareholder favors the payout, another, as in Sinclair, may perceive that the opportunity cost of the payoutforgoing an investment in capital that would increase firm size, say-outweighs the value of the payout. Id. at 720 . 
payments as a reasonable exercise of business judgment. ${ }^{218}$ Further, a controlling shareholder can control the timing and form of corporate distributions (for example, dividends as opposed to share repurchases), which may confer significant tax advantages on it, but not on other shareholders. ${ }^{219}$

Third, a controlling share investment comes with the ability to direct operations and thus is a lower risk investment, on a per share basis, than an investment in shares that lack control. The controlling shareholder does not face the risk, faced by the minority shareholder, that the corporation will come under the control of others who may do a poor job managing the corporation, try to expropriate assets, or run it solely to benefit the business of others. ${ }^{220}$ The controlling shareholder thus is likely to value the controlling shares more highly, relative to other shares. ${ }^{221}$

Fourth, in addition to the form of corporate distribution advantage mentioned above, a controlling shareholder may be able to gain tax and accounting advantages unavailable to a minority shareholder of the same corporation. For example, a corporation that holds $80 \%$ of a couple of subsidiaries will be able to write off the losses of one subsidiary against the income from another. Further, the tax treatment of dividends is different: A corporation that receives dividends from another corporation that is a member of the same "affiliated group" will pay no taxes on the dividends at all; a corporation that owns $20 \%$ or more of a distributing corporation will be able to deduct $80 \%$ of the dividend before taxes are calculated. By comparison, a corporation that holds a minority interest can deduct $70 \%$ of the dividend, while an individual who owns a minority interest will pay ordinary income tax on $100 \%$ of the dividends. ${ }^{222}$

Moreover, an $80 \%$ controlling shareholder will be able to file consolidated tax returns even if the shareholder does not own all the cash flow from the subsidiary. This might make the shareholder's cash flow look high and make financing easier to obtain. In other words, a controlling

218. Id. at $72 \mathrm{I}-22$.

219. For example, individual shareholders would normally prefer sale or exchange distributions to dividends because they could have gains taxed at capital gains rates, rather than ordinary rates (and only the portion of proceeds in excess of the basis is taxed). Corporate shareholders, however, may prefer dividends because corporations, especially those with large controlling shares, can take the dividends-received deduction. Scholes et al., supra note 42 , at 3 II.

220. Edward F. Greene \& James J. Junewicz, A Reappraisal of Current Regulation of Mergers and Acquisitions, 132 U. Pa. L. Rev. 647, 660 (I984).

221. See Coates, supra note 212, at 1277 (noting that because of value attached purely to management capacity, "pure control value may be considerably higher than intuition would suggest"); cf. Hansmann \& Kraakman, Unlimited Liability, supra note 2, at I890 ("Differences in risk aversion or in the form of investment (for example, human capital versus financial capital) inevitably lead shareholders to value a firm's potential projects differently.").

222. See Douglas A. Kahn \& Jeffrey S. Lehman, Corporate Income Taxation $\$ \$ 2.2 . I-.2$ (5th ed. 2001) (discussing tax treatment of dividends as ordinary income and dividend-received deductions for corporate shareholders). 
shareholder might be able to reduce its overall cost of capital by virtue of control ownership in a corporation with positive cash flow. ${ }^{223}$

Fifth, the buyer of a controlling share can gain additional value because, depending on the size of the controlling share, the controlling shareholder may have the option of cheaply acquiring the shares held by minority shareholders. ${ }^{224}$ Because a controlling shareholder can affect dividend payout schedules and the timing of earnings reports, the buyer may be in a position to depress the value of the minority shares and gain additional value from the repurchase of those shares on favorable terms. ${ }^{225}$

Moreover, a controlling shareholder's opportunities to obtain most, if not all, of these control-based benefits likely will increase as a corporation takes on new projects and grows in size. For example, as a corporation expands, a controlling shareholder's ability to obtain tax advantages, such as the deduction for dividends and the ability (in the case of an $80 \%$ shareholder) to write off losses of one subsidiary against the income of another, clearly will increase. And a controlling shareholder's opportunity to benefit by altering the form of corporate distribution also will increase as the corporation undertakes more projects. Thus, a controlbased shareholder likely will benefit in excess of that shareholder's pro rata share of ownership not only from corporate activity in general, but from a particular new project, risky or not.

Finally, while not every controlling shareholder may be able to avail itself of each of these sources of additional per-share value, the controlling shareholder can sell the control block to a buyer that will value control for these reasons and, accordingly, will pay a premium. In such a transaction, the controlling shareholder will capture some of the surplus attributable to these additional sources of value. This type of transaction

223. Id.; Telephone Interview with Bruce Gutenplan, Partner, Paul, Weiss, Rifkind, Wharton \& Garrison (Sept. 29, 2000).

224. See In re Sea-Land Corp. S'holders Litig., 642 A.2d 792, 802 (Del. Ch. 1993) ("Under Delaware law, a purchaser may acquire a block of stock from one shareholder at a premium, and thereafter may offer a lower price for the corporation's remaining shares."); see also Ragazzo, supra note 194, at 1002 (observing that minority shareholders' investment value depressed by sale of controlling interest).

225. E.g., Dent, supra note 189, at 890 ("Shareholders . . . want dividends. Managers prefer to retain earnings."); Goshen, supra note 188, at 887-88 (contending that managers prefer to retain excess earnings in part to increase corporate size and in part to decrease business failure risks); see Coates, supra note 212, at 1275-76 (stating that control premium may include value of ability to undertake "freezeouts priced to take advantage of a 'blockage' of non-material information"). Again, while majority shareholders possess a fiduciary duty toward minority shareholders, that duty is unlikely to constrain this type of activity. See Lucian Arye Bebchuk, Toward Undistorted Choice and Equal Treatment in Corporate Takeovers, 98 Harv. L. Rev. 1695, 1709 (1985) ("Current takeout law allows successful bidders to pay minority shareholders a consideration with a nominal value lower than the bid price."); Ragazzo, supra note 194, at 1002 (arguing that negative impact of controlling interest sale on minority shareholders' investments justifies requiring company to prove "that control provides the largest possible benefits to shareholders"). 
is likely because the vast majority of corporate acquisitions take place through transactions other than tender offers. ${ }^{226}$ In these transactions, a buyer seeking control likely will prefer to approach a controlling shareholder rather than trying to assemble a controlling share from minority shareholders. The buyer generally can more easily obtain control by purchasing a block of shares from a shareholder that already possesses control.

Nor are minority shareholders likely to benefit when the controlling shareholder sells its shares. The controlling shareholder is free to sell its controlling ownership interest at any price it can negotiate, even if that price is not available to minority shareholders. The seller of a controlling share need not share the premium with other shareholders. ${ }^{227}$ The premium paid represents an immediate gain for the controlling shareholder. ${ }^{228}$ Further, once the acquirer has paid a premium to the controlling shareholder and acquired control, the acquirer is unlikely to pay any premium to purchase the shares of minority shareholders. ${ }^{229}$

An analysis of the extra value attributable to control raises a number of further questions that are beyond the scope of this Article, such as the size of the unique benefit that controlling shareholders can gain. For example, while a controlling shareholder clearly can obtain value not shared with other shareholders, some of the premium such a shareholder is willing to pay for control certainly could include benefits shared pro rata with other shareholders, such as increased dividends that would

226. In 1998, tender offers accounted for only $2.2 \%$ of all 9129 corporate acquisitions, although they accounted for $8.3 \%$ of the total dollar volume. The Fastest Lane $1 n$ the Deals Market, Mergers \& Acquisitions, Mar.-Apr. 1999, at 23, 23.

227. For example, in Citron v. Steego Corp., the court held:

Our law does not regard a control premium as a corporate asset that must be shared among all shareholders. A fortiori a shareholder without control, even if he is a director, and thus owes a duty of loyalty to the corporation and its shareholders, may qua shareholder negotiate the sale of his stock on whatever terms he is able to arrange.

Civil Action No. 10171, 1988 Del. Ch. LEXIS 119, at *21 (Del. Ch. Sept. 9, 1988) (internal citations omitted); see also Principles, supra note 199 , $\$ 5.16$ (stating that controlling shareholder has "right to dispose of voting equity securities . . for a price that is not made proportionally available to otber shareholders"). Of course, to the extent a control buyer acquires control by making a tender offer, that price must be made available to all tendering shareholders. Securities Exchange Act of $1934 \S 14(\mathrm{~d})(7), 15$ U.S.C. $\S 78 \mathrm{n}(\mathrm{d})(7)(1994)$.

228. Alfred Rappaport, Creating Shareholder Value: A Guide for Managers and Investors 159 (2d ed. 1998).

229. See Ragazzo, supra note 194, at 1002 (stating that minority shareholders would lack "opportunity to sell their stock at a premium in the future"); see also Bebchuk, supra note 225, at 1696 (noting that minority shareholders expect that shares after takeover will be worth less than bid price). A controlling shareholder could, of course, have already paid a premium for a control block that sbe later tries to sell at a premium and could take a loss on the sale if, for example, she overpaid initially in purchasing the control block. The point, however, is that the controlling shareholder has an asset to sell-the ability to control the corporation and to profit from synergies and other opportunities-that does not belong to minority shareholders. 
come with an improvement in management. Another such question is whether unique control benefits would tend to increase proportionately with the size of a company. In public corporations, for example, an increase in a company's size might be correlated with greater marketplace monitoring. This might reduce the extent to which a controlling shareholder might take "synergistic" opportunities. ${ }^{230}$ In addition, some control benefits could vary with the size of the controlling share held. For example, some tax benefits are not available to a shareholder with less than an $80 \%$ share. Moreover, a shareholder with a bare majority seeking to take synergy opportunities could face a greater risk of a fiduciary duty suit filed by minority shareholders.

ln general, though, the controlling shareholder or parent can realize a benefit from a new corporate activity in excess of its pro rata share. Depending on the structure and operation of the corporation and the controlling shareholder's other businesses, the benefit could substantially exceed the pro rata share. Moreover, leaving aside the small chance of vicarious liability, there seems no obvious reason why a controlling shareholder would benefit any less when the corporation's new project is a risky one. ${ }^{231}$

Thus, a corporation whose equity is held in whole or in part by a shareholder with a capacity to control the corporation is more likely to select excessively risky activities. Because of the greater ability to benefit, a controlling shareholder is more likely to find hazardous activities attractive and to prompt corporate management to approve the activities that present the small risk of a large loss. The shareholder can more effectively monitor corporate management's conduct so as to ensure that management will maximize profits on the shareholder's behalf, and the shareholder is in a better position to ensure that it promptly reaps the benefits of the activity through dividend payments. The corollary is that, under limited liability, there is a set of risky activities that a company with a dispersed share ownership would not select, but a company with a controlling shareholder would.

230. Some control-related henefits-such as a corporation choosing to contract with a corporation related to the controlling shareholder rather than seeking the lowest biddercould be less likely if there is greater market monitoring. Further, the amount of such activity may vary with the level of control. For example, a parent company that owns all or virtually all of a subsidiary may be perfectly comfortable contracting with a subsidiary, while an $80 \%$ owner may be deterred by the risk of a minority shareholder suit brought for breach of fiduciary duty.

231. Arguably, a shareholder's possession of additional control might reduce the value to the shareholder of excessively hazardous corporate activity because the control would increase the shareholder's liability exposure under the veil piercing doctrine. The risk of greater liability exposure under the veil piercing doctrine, however, appears to be very small. See infra text accompanying notes 233-253. 


\section{E. Possible Neutralizers}

Some commentators have identified features, either of the legal system or of corporate structure, that might tend to blunt the effect of limited liability's moral hazard. Five major possibilities have been identified: (1) current veil piercing rules; (2) managerial risk aversion; (3) new statutes purporting to bypass limited liability rules; (4) fraudulent conveyance rules; and (5) free transferability of shares in publicly-traded corporations. ${ }^{232}$ However, none of these is likely to compensate adequately for excessive risk taking, especially when a controlling shareholder or parent corporation is present.

1. Veil Piercing Rules. - Current equitable veil piercing rules are not a significant deterrent for companies that want to rely on limited liability as a means of reducing liability exposure for hazardous activities. Although there are some limited exceptions, current law generally retains limited liability for a corporate shareholder even when the shareholder exerts a considerable degree of influence-or even direct control-over corporate action.

Corporate shareholders, with or without some level of control, generally have limited liability unless they have liability arising directly from their own conduct, ${ }^{233}$ a statute imposes liability upon them, or a court pierces the corporate veil. ${ }^{234}$ Since this Article focuses on vicarious shareholder liability, the first exception need not be discussed further. The second is relatively rare and looks to be unsuccessful. ${ }^{235}$ Veil piercing is the primary means of holding shareholders vicariously responsible for corporate torts.

232. A sixth suggestion-a judicial doctrine that corporate managers have a duty of some kind to creditors-is not available under current law. See Lynn M. LoPucki, The Irrefutable Logic of Judgment Proofing: A Reply to Professor Schwarcz, 52 Stan. L. Rev. 55, 68-69 (1999). Compulsory insurance and minimum capitalization requirements are likely to represent incomplete solutions. See supra note 7.

233. See, e.g., Browning-Ferris Indus. of Ill., Inc. v. Ter Maat, 195 F.3d 953, 955 (7th Cir. 1999) ("[T]he status of being a shareholder does not immunize a person for liability for his, as distinct from the corporation's, acts.").

234. Of course, the shareholder may also agree to take on liability.

235. The federal Superfund law, otherwise known as the Comprehensive Environmental Response, Compensation, and Liability Act of 1980, or CERCLA, 42 U.S.C. $\$ \S 9601-9675$ (1994 \& Supp. V 1999), is a notable example of an attempt to create statutory liability for shareholders. See infra note 265 (discussing cases imposing liability directly on shareholders as "operators"). However, the effectiveness of such attempts to impose shareholder liability notwithstanding limited liability has been undermined by decisions like United States v. Bestfoods, 524 U.S. 51 (1998). See infra text accompanying notes 264-273 (discussing parent corporation liability under CERCLA). Further, very few state laws expressly impose responsibilities directly on corporate shareholders. See, e.g., N.Y. Bus. Corp. Law $\S 630$ (1961) (imposing responsibility for employee wage claims on ten Iargest shareholders); Wis. Stat. Ann. $\$ 180.0622(2)$ (b) (West 1992) (making all shareholders - with some exceptions-personally liable for wage claims up to amount of consideration paid for shares). 
Currently, limited liability protections are equally available to individual shareholders and corporate shareholders, such as parent corporations. Veil piercing doctrine does not distinguish explicitly between the individual shareholder and one that is a corporate entity. While the extent of corporate ownership and actual influence over corporate decisionmaking may be relevant to some of the equitable factors considered by a court, the veil piercing doctrine also does not focus specifically on shareholders that are in a position to control the corporation.

While judicial veil piercing rhetoric often is framed broadly in terms of precluding the use of a legal entity to "defeat public convenience, justify wrong, protect fraud, or defend crime," 236 courts rarely pierce the veil. There is considerable variation among states, and between state common law doctrines and federal common law. However, judicial veil piercing inquiries generally focus on whether the corporate form has been used to accomplish "fraud, injustice, or the like" and whether the "subsidiary was 'a mere instrumentality of the parent corporation.' "237 To satisfy this "mere instrumentality" requirement, also known as the "al-

236. United States v. Milwaukee Refrigerator Transit Co., 142 F. 247, 255 (C.C.E.D. Wis. 1905); see also Kelley v. Austell Bldg. Supply, Inc., 297 S.E.2d 292, 297 (Ga. Ct. App. 1982) (" $[\mathrm{T}]$ he corporate fiction . . . may be disregarded where the defendant has over extended [sic] his privilege in the use of a corporate entity in order to defeat justice, perpetrate fraud or to evade contractual or tort responsibility.").

237. State Dep't of Envtl. Prot. v. Ventron Corp., 468 A.2d 150, 164 (N.J. 1983) (quoting Mueller v. Seaboard Commercial Corp., 73 A.2d 905, 908 (N.J. 1950)) (applying New Jersey law); New York v. Shore Realty Corp., 759 F.2d 1032, 1052 (2d Cir. 1985) (noting under New York law, veil can be pierced only if "corporate form is being used fraudulently or as a means of carrying on business for personal rather than corporate ends"); L.B. Indus. v. Smith, 631 F. Supp. 922, 926 (D. ldaho 1986) (describing unity of interest and inequitable result necessary to pierce veil under ldaho law). While state doctrines do vary, most of them, like those of New York and New Jersey, require some indication that the corporation is the shareholder's "alter ego" and that "fraud" is present. For example, in Pennsylvania, "[f]actors which may justify disregarding the corporate form include undercapitalization, failure to adhere to corporate formalities, substantial intermingling of corporate and personal affairs and use of the corporate form to perpetrate a fraud." Kaites v. State Dep't of Envtl. Res., 529 A.2d 1148, 1151 (Pa. Commw. Ct. 1987). In Ohio, a court must find, as a prerequisite to veil piercing, that control by the shareholder "was so complete that the corporation has no separate mind, will, or existence"; that the control "was exercised in such a manner as to commit fraud or an illegal act"; and "injury or unjust loss resulted to the plaintiff." Belvedere Condo. Unit Owners' Ass'n v. R.E. Roark Cos., 617 N.E.2d 1075, 1086 (Ohio 1993). By comparison, Texas takes a "flexible fact-specific approach focusing on equity." Castleberry v. Branscum, 721 S.W.2d 270, 273 (Tex. 1986), reh'g denied (1987), cited in Matthews Constr. Co. v. Rosen, 796 S.W.2d 692, 693-94 (Tex. 1990). That approach, however, subsumes instances in which the "fiction is used as a means of perpetrating fraud" or "where a corporation is organized ... as a mere tool or business conduit of another corporation." Castleberry, 721 S.W.2d at 272. See infra note 240 (discussing Castleberry). For an example of highly questionable shareholder conduct, see, e.g., People v. V \& M lndus., 700 N.E.2d 746, 751-53 (111. App. 1998) (piercing corporate veil where there was undercapitalization, failure to issue stock, "failure to observe corporate formalities," absence of dividend payments, absence of corporate records, company was insolvent at trial, "corporate officers and directors were nonfunctioning," and corporation "was a mere facade for the operation 
ter ego" requirement, a claimant typically must show that the owner so dominated the subsidiary that it "had no separate existence but was merely a conduit for the parent."238 This largely turns on the absence of corporate formalities-the intertwining of checking accounts, the parent's use of the subsidiary to transact the parent's business, or the lack of subsidiary directors' or shareholders' meetings. ${ }^{239}$

While showing that a shareholder holds a substantial ownership stake is relevant, and perhaps even necessary, for a judicial finding that a corporation serves as a shareholder's "conduit," the showing of a substantial ownership stake or even the close intertwining of parent and subsidiary management is not sufficient, under present law, to hold a shareholder responsible for corporate torts. Because courts generally look for the absence of corporate formalities, demonstrating substantial ownership or control generally is not adequate to show either that the corporation is the shareholder's alter ego or that "the parent has ... us[ed] the subsidiary to perpetrate a fraud or injustice, or otherwise to circumvent the law." 240 Nor is proof that the subsidiary has committed a tort (apart, in some circumstances, from torts involving fraudulent representation re-

of the dominant stockholder"). See generally Presser, Piercing, supra note 16, \& 2 (1991 \&c Supp. 1998) (discussing veil piercing standard and variations on state-by-state basis).

238. Ventron, 468 A.2d at 164.

239. One example is the Supreme Court's decision in Chicago, Milwaukee \& St. Paul Ry. Co. v. Minneapolis Civic \& Commerce Ass'n, 247 U.S. 490, 494, 496-99 (1918), finding that a railway suhsidiary was a "mere agency or instrumentality" of its two $50 \%$ shareholders. The subsidiary had no stations or freight depots, only two engines, and twenty to thirty employees; it was managed by a "Managing Committee" that consisted of the general manager of one shareholder and the general superintendent of the other. The shareholders selected the superintendent and exercised approval over business agreements. Seven of the nine members of the subsidiary's board of directors were officers of one of the two parents.

240. Ventron, 468 A.2d at 164; cf. Castleberry, 721 S.W.2d at 272 ("[T]he separateness of the corporation has ceased."). The Castleberry court took a relatively liberal approach to "alter ego" veil piercing, however, requiring no fraud or inequitable conduct, but instead holding that alter ego could be shown:

[F]rom the total dealings of the corporation and the individual, including the degree to which corporate formalities have been followed and corporate and individual property have been kept separately, the amount of financial interest, ownership and control the individual maintains over the corporation, and whether the corporation has been used for personal purposes.

Id. Reacting to Castleberry, the Texas legislature amended its corporate code in 1989 to specifically overrule any suggestion in that opinion that a failure to observe corporate formalities could be a factor in proving an "alter ego" theory. See Tex. Rev. Civ. Stat. Ann. art. 2.21 (A) (3) (Vernon 1993); W. Horizontal Drilling, Inc. v. Jonnet Energy Corp., 11 F.3d 65, 68 (5th Cir. 1994).

The federal common law standard has been described as more flexible. See Presser, Piercing, supra note 16, 3.01 \& n.5 (1991 \& Supp. 1998) (citing Leddy v. Standard Drywall, Inc., 875 F.2d 383, 387 (2d Cir. 1989)) ("Several federal courts have developed a federal common law . . . that allows for more easy piercing.”); Capital Tel. Co. v. FCC, 498 F.2d 734, 738-39 (D.C. Cir. 1974). However, that trend seems undermined by United States v. Bestfoods, 524 U.S. 51 (1998). 
garding the corporation's owners ${ }^{241}$ ) generally sufficient to show fraud justifying veil piercing. ${ }^{242}$

While courts have also stated that veil piercing may be warranted if the subsidiary is undercapitalized at the time of its creation, in view of the reasonably expected costs of running the business, this type of veil piercing too is rare. ${ }^{243}$ As a practical matter, undercapitalization must be egregious before a court will pierce the corporate veil. ${ }^{244}$ if the corporation has been properly capitalized at the outset, later operation with clearly insufficient assets to cover the corporation's tort liabilities will not suffice to show undercapitalization. ${ }^{245}$ Even undercapitalization ex ante generally has been insufficient by itself for a court to justify piercing the corporate veil. ${ }^{246}$ ln cases where corporations have been found to be undercapitalized at the outset and the corporate veil is pierced, another factor, such as the lack of corporate formalities, almost always has been present. $^{247}$

241. For example, a corporation might lead "potential creditors to believe that it [is] more solvent than it really [is]." Browning-Ferris Indus. of Ill., Inc. v. Ter Maat, 195 F.3d 953, 959 (7th Cir. 1999).

242. Needless to say, perhaps, if proof of a corporate tort were sufficient to show that the corporate form had been used to circumvent the law, that prong of the veil piercing test would be rendered extraneous in all tort cases. See, e.g., Aronson v. Price, 644 N.E.2d $864,867-69$ (Ind. 1994) (engaging in separate analysis of "injustice" in determining whether to pierce veil to shareholder and holding that a corporation's failure to file an amended husiness name certificate with the state, while a hreach of corporate formalities, was not sufficient to impose personal liability on shareholders); see also Huffman v. Poore, 569 N.W.2d 549, 557 (Neb. App. 1997) (holding that veil will be pierced "only where the corporation has been used to commit fraud, violate a legal duty, or perpetrate a dishonest or unjust act in contravention of the rights of another").

243. See, e.g., Anderson v. Abbott, 321 U.S. 349, 362 (1944) ("An obvious inadequacy of capital, measured by the nature and magnitude of the corporate undertaking, has frequently been an important factor" in deciding whether to pierce corporate veil); In re Acushnet River \& New Bedford Harbor Proceedings re Alleged PCB Pollution, 675 F. Supp. 22, 33 (D. Mass. 1987) (citing inadequate capitalization as one of several factors relevant to veil piercing inquiry).

244. See Thompson, Empirical Study, supra note 146, at 1066 (discussing refusal to pierce in $25 \%$ to $30 \%$ of cases where undercapitalization is present).

245. E.g., Kaplan v. First Options of Chi., 1nc., 19 F.3d 1503, 1523 (3d Cir. 1994) (repayment of stockholder loans when corporation was apparently insolvent did not "justify piercing the corporate veil" to stockholder).

246. The Seventh Circuit, applying lllinois law, recently interpreted adequate capitalization, for veil piercing purposes, as maintaining merely "the minimum capitalization required by law." Ter Maat, 195 F.3d at 961; see also Pel-Star Energy, lnc. v. United States Dep't of Energy, 890 F. Supp. 532, 546 n.20 (W.D. La. 1995) ("This startling leap from undercapitalization to personal liability is legally insufficient to support piercing the veil."). Minimum capitalization requirements are not likely to be a meaningful constraint. William P. Hackney \& Tracey G. Benson, Shareholder Liability for Inadequate Capital, 43 U. Pitt. L. Rev. 837, 843 (1982) (observing the nonexistent or nominal nature of state minimum capitalization requirements).

247. "Undercapitalization is rarely if ever the sole factor in a decision to pierce the corporate veil." Ter Maat, 195 F.3d at 961 . In his empirical study of 1600 judicial opinions through 1985 in which plaintiffs sought to pierce the corporate veil, Thompson notes that 
In short, a shareholder may maintain limited liability despite a high degree of potential or actual control over a corporation's activity. Extensive control of a corporation by a shareholder-including selection of the subsidiary's board of directors and control over major financial decisions-is treated by courts as fairly run-of-the-mill and is unlikely to create a significant risk of veil piercing. ${ }^{248}$ Controlling shareholders can ensure that their interests are fully represented on the subsidiary's board of directors, or by commonly employed officers, as well as that they have influence over both large and small corporate decisions, either directly, for some decisions, or through the board. ${ }^{249}$ Parent corporations can weigh in heavily on a subsidiary's decision to take on debt and on management and operational decisions. For example, in the case of corporate activity presenting environmental risks, a parent might influence the decision to purchase pollution control equipment, litigation decisions, and, of course, decisions on the timing and amount of corporate distributions. ${ }^{250}$ Under current doctrine none of these activities normally will justify a court piercing the veil. ${ }^{251}$

undercapitalization was discussed only in a "small minority of the cases," and that courts "refused to pierce in 25 to $30 \%$ of the cases even when undercapitalization was present." Thompson, Empirical Study, supra note 146, at 1066. Thompson does not discuss whether undercapitalization was the sole factor in any case justifying piercing the corporate veil. See also Presser, Piercing, supra note $16, \S 1.05$ [2] (stating that undercapitalization is a relevant but rarely dispositive factor in deciding whether to pierce the veil).

Some commentators have cited Minton $v$. Cavaney as a case where undercapitalization alone justified piercing the corporate veil. 364 P.2d 473 (Cal. 1961). The Minton court pierced the corporate veil in connection with a drowning in a swimming pool because the capital of the corporation was "trifling compared with the business to be done and the risks of loss." 'Id. at 475 (quoting Automotriz Del Golfo De California S. A. De C. V. v. Resnick, 306 P.2d 1, 4 (Cal. 1957)). In Minton, however, as Presser has pointed out, the court was presented not only with undercapitalization, but with a lack of corporate formalities distinguishing the corporation from its owners-an alter ego problem. See Presser, Piercing, supra note $16, \S 1.05[2]$ n.16.

248. E.g., United States v. Bestfoods, 524 U.S. 51, 71-72 (1998) (holding that parent company that actively participated in and controlled subsidiary's operations may not, without more, be held derivatively liable under CERCLA for pollution from subsidiary's facility).

249. E.g., Datron, Inc. v. CRA Holdings, lnc., 42 F. Supp. 2d 736, 748 (W.D. Mich. 1999) (holding parent and subsidiary's employment of common officer not beyond "the parameters of normal oversight by a parent corporation over its subsidiaries"); AT\&T Global Info. Solutions Co. v. Union Tank Car Co., 29 F. Supp. 2d 857, 867 (S.D. Ohio 1998) ("Ohio law permits one corporation to own all of the stock of another corporation as well as to employ common officers and directors, as well as other personnel, without risking veil piercing.").

250. E.g., Aron M. Bookman, Note, Transcending Common Law Principles for Limited Liability of Parent Corporations for the Environment, 18 Va. Envtl. L.J. 555, 600 (1999) ("A parent could be fully aware of an environmental disaster, contribute to its creation through general mandates, make a substantial profit, and not be liable, even though it is arguably responsible.").

251. See Bainbridge, supra note 7 , at 514 (arguing that observing corporate formalities and avoiding haphazard withdrawal of funds or commingling of funds probably sufficient to avoid veil piercing). 
Similarly, that a corporation lacks sufficient assets even to address liabilities likely to flow from its operations generally is insufficient to pierce the veil. A shareholder may even influence a corporation to divest itself of assets (through, for example, the payment of dividends) without endangering limited liability protections. Shareholders thereby can demand distributions from corporate activity, even if that may leave the corporation with relatively insignificant operating reserves. ${ }^{252}$

In short, a shareholder must work hard to dominate every aspect of a subsidiary's operations and also disregard corporate formalities (such as holding board meetings or preparing corporate minutes) or engage in fraud in order to run afoul of current veil piercing rules. In most jurisdictions, the exercise of extensive control over corporate management, including influencing management to pay distributions and to operate the corporation with reserves inadequate to pay tort claims against the corporation, will not result in veil piercing absent a showing of disregard of corporate formalities or fraud. ${ }^{253}$

2. Managerial Risk Aversion. - As discussed above, managerial risk aversion generally tends to blunt limited liability's incentive for excessive corporate risk taking. ${ }^{254}$ However, managers can express their risk aversion preferences only to the extent that they are not tightly constrained by shareholders. The greater the degree of shareholder control, the less the degree of expressed managerial risk aversion, since managers will have reduced latitude to serve their own goals in preference to maximizing shareholder welfare. Thus, managerial risk aversion will have greater play when shareholder control is relatively low. For example, when all shareholders hold less than $1 \%$ of stock, exercising control over management will be more difficult. Where a shareholder with control is present, however, managerial risk aversion is unlikely to prevent excessive risk taking. ${ }^{255}$

252. E.g., Walkovszky v. Carlton, 223 N.E.2d 6, 11 (N.Y. 1966) (Keating, J., dissenting) (noting that "all income was continually drained out of the corporations").

253. White argues that veil piercing is likely if a parent "routinely drain[s] the subsidiary of its assets while satisfying the subsidiary's contract creditors." White, supra note 50, at 1401. Such veil piercing, however, is likely to be the rare exception. Even the example given by White, Eastridge Dev. Co. v. Halpert Assocs., 853 F.2d 772 (10th Cir. 1988), involved corporate conduct significantly more egregious than a parent's influencing of a corporation to make large distributions. The parent company in that case arranged for all the corporation's revenues to be paid directly to the parent and asserted control over all the subsidiary's expenses as well. Id. at 776 . Corporate formalities were disregarded; the two corporations lacked any separateness at all. Id.

254. See supra text accompanying notes 188-191.

255. Easterbrook and Fischel also argue that managerial fear of job loss may encourage a firm to pay a premium in the form of additional insurance. Easterbrook \& Fischel, Economic Structure, supra note 6, at 53. Certainly, managerial risk aversion might lead a larger corporation to purchase insurance where a corporation with a single individual owner-manager would not. As Easterbrook and Fischel acknowledge, however, firms may find it cheaper simply to pay a premium directly to a risk averse manager rather 
3. Statutory Tort Law Changes. - Several commentators also have argued that state and federal statutes might succeed in impeding corporate attempts to use subsidiaries to limit tort liability. ${ }^{256}$ Shareholders are directly liable under the common law for torts they commit, even when the shareholder purports to act on the corporation's behalf. ${ }^{257}$ Some statutes that impose tort-type liability on a broader range of conduct than at common law also could be read to impose that responsibility directly on shareholders. Consequently, shareholders might have statutory responsibility for corporate actions that, at common law, would not have exposed the shareholder to tort liability either directly or vicariously. According to these commentators, the strongest such statute appears to be the Comprehensive Environmental Response, Compensation, and Liability Act (CERCLA, or Superfund), ${ }^{258}$ which imposes liability for cleaning up hazardous substance releases on a wide array of parties connected with the release, including the entity that "arranged for disposal" of the hazardous substance, the transporter, and the owner and operator of the facility where the release occurred. CERCLA's liability section is perceived as a fairly radical attempt to expand liability for cleanup costs, notwithstanding the restraints that might be imposed by a host of common law tort and corporations rules. ${ }^{259}$ Caselaw under CERCLA over the last fifteen years or so also has been perceived to be "eroding" traditional corporation law concepts such as limited liability. ${ }^{260}$

A few other federal environmental statutes, including the federal Clean Air Act and Clean Water Act, impose liability on polluting behavior with language similar to that of CERCLA. ${ }^{261}$ A number of state environ-

than to buy insurance, especially for large potential losses. Firms may even pay managers a premium while "simultaneously decreas[ing] their capitalization." Id. at 54.

256. See, e.g., Blumberg, Increasing Recognition, supra note I62, at 324 \& nn.100-02 (noting courts' expansive construction, with concurrent conservative opposition, of environmental statutes that impose liability on parent corporations for subsidiaries' actions); Lynda J. Oswald \& Cindy A. Schipani, CERCLA and the "Erosion" of Traditional Corporate Law Doctrine, 86 Nw. U. L. Rev. 259, 263 (1992) (defending court holdings as to shareholder and parent CERCLA liability as in accordance with traditional corporate law principles); Cindy A. Schipani, Infiltration of Enterprise Theory into Environmental Jurisprudence, 22 J. Corp. L. 599, 601 (1997) ("[E]nterprise liability is making its debut in CERCLA jurisprudence."); White, supra note 50, at 1404 ("[S] tate and federal statutes that explicitly decline to recognize corporate separateness of parties might thwart judgment proofing through subsidiaries."); see also Menell, supra note 123, at 410-14 (noting some legal uncertainty regarding "liability of parent corporations for the environmental harms of their subsidiaries").

257. E.g., United States v. Bestfoods, 524 U.S. 51, 64-65 (1998) (distinguishing direct and vicarious shareholder liability).

258. 42 U.S.C. $\S \S 9601-75$ (1994 \& Supp. V 1999).

259. See Black, Shareholder Passivity, supra note 69, at 549-50 (discussing CERCLA and securities laws); White, supra note 50, at 1404 ("[T] he most notable of these [liability expanding statutes] is [CERCLA].").

260. See Oswald \& Schipani, supra note 256, at 259.

261. Clean Water Act, 33 U.S.C. $\$ \S 1321$ (b) (6), (f) (1994) (imposing penalties and removal costs liability on "owner [or] operator" of vessel or facility from which oil or 
mental cleanup statutes have similar language as well. ${ }^{262}$ Other statutes that arguably impose responsibility for corporate statutory violations directly on shareholders are Section 15 of the Securities Act of 1933 and Section 20(a) of the Securities Exchange Act of 1934, which impose responsibility for securities fraud on a person who "controls" any liable person, subject to a "good-faith" defense. ${ }^{263}$

Indications are, however, that such statutory efforts to hold shareholders directly liable for corporate torts, as they currently stand, are unlikely to substitute for directly revisiting vicarious liability rules. The purported "erosion" of traditional corporation law concepts under CERCLA, for example, was set back sharply in 1999. In United States v. Bestfoods, the Supreme Court interpreted CERCLA to include concepts drawn from limited liability, thereby creating a safe harbor from statutory liability for parent corporations. ${ }^{264}$

Prior to Bestfoods, it was not clear that courts would apply CERCLA or other environmental law statutes to hold a parent company directly liable for environmental injury from a subsidiary's operations when there would be no liability under traditional corporation law doctrines. The federal courts of appeals had split regarding whether a parent company could, based on control exercised over a subsidiary, be an "operator" of the subsidiary's disposal facility, so that CERCLA would impose liability for cleanup costs on the parent company. ${ }^{265}$

hazardous substance is released into water); Clean Air Act, 42 U.S.C. $\$ 7412$ (a) (9) (1994) (defining "owner or operator" to include one that "controls" stationary source); id. $\$ 7413$ (b) (imposing penalties on "owner or operator" of affected source not in compliance with permit); see also United States v. Anthony Dell'Aquilla, Enters. \& Subsidiaries, 150 F.3d 329, 329 (3d Cir. 1998) (holding that Clean Air Act imposes strict liability on owners and operators). One court also has imposed liability directly on corporate shareholders and officers under the federal Rivers and Harbors Act. 1n United States v. Pollution Abatement Services, two corporate officers who were "personally involved in or directly responsible" for the discharge of refuse and storage of thousands of drums of chemicals on the banks of a creek were held directly liable. 763 F.2d 133, 135 (2d Cir. 1985). But see United States v. Sexton Cove Estates, Inc., 526 F.2d 1293, 1300-01 (5th Cir. 1976) (holding that corporate president with personal involvement in dredging decisions was not liable under Rivers and Harbors Act because Congress did not expressly impose liability on corporate officers).

262. See, e.g., N.J. Stat. Ann. $\$ 58: 10-23.11$ g(c) (1) (West 1992); see also Marsh v. N.J. Spill Comp. Fund and Envtl. Claims Admin., 670 A.2d 67, 69-70 (N.J. Super. Ct. App. Div. 1996) (holding that "[olwnership or control over the property at the time of discharge" suffices for liability under New Jersey statute).

263. 15 U.S.C. $\$ \$ 77 \mathrm{o}, 78 \mathrm{t}$ (a) (1994). In enacting these statutes, Congress was concerned with the "substantial threat posed by persons with authority to control who default on their responsibility for Securities Acts compliance and by other persons with significant power bases who manifest their actual control without due regard for Securities Acts compliance." Carson, supra note 196, at 280.

264. 524 U.S. 51, 51-52 (1998).

265. See Schiavone v. Pearce, 79 F.3d 248, 248 (2d Cir. 1996) (stating that corporation's CERCLA liability "stemmed directly from its control over subsidiary's creosoting plant"); Lansford-Coaldale Joint Water Auth. v. Tonolli Corp., 4 F.3d 1209, 1222 n.13 (3d Cir. 1993) (finding that parent company with "pervasive control" would be 
In Bestfoods, the Court granted certiorari on a question of a parent corporation's direct liability as a CERCLA "operator" for cleaning up the polluted chemical manufacturing facility of its subsidiary. The parent company, CPC International (later renamed Bestfoods), had purchased a chemical manufacturing company through a wholly-owned subsidiary. Several individuals served simultaneously as managers at both the parent and the subsidiary, the parent controlled the subsidiary's finances, and a parent company employee actively participated in environmental matters. The question was whether the parent company had "operated" the subsidiary's facility within the meaning of CERCLA's liability provisions.

The Court stated that it viewed limited liability for corporate shareholders, including parent companies, as a "bedrock principle" to be rarely disrupted and suggested that the corporate veil was appropriately pierced only on a showing that the corporate form was used for wrongful purposes such as fraud. ${ }^{266}$ The Court also cited cases suggesting that it would look for the presence of an alter ego relationship. ${ }^{267}$ Based on the limited availability of veil piercing, the Court then reasoned that parent companies normally had a safe harbor for certain types of activities, including "the election of directors, the making of by-laws ... and the doing of all other acts incident to the legal status of stockholders.' "268 The Court added that "a duplication of some or all of the directors or executive officers" would not prove fatal. ${ }^{269}$

CERCLA operator); Jacksonville Elec. Auth. v. Bernuth Corp., 996 F.2d 1107, 1110 \& n.3 (11th Cir. 1993) (stating that parent corporation that exercises "actual and pervasive control" " of subsidiary would be CERCI.A operator) (quoting Jacksonville Elec. Auth. v. Eppinger \& Russell Co., 776 F. Supp. 1542, 1547-48 (M.D. Fla. 1991)); Nurad, lnc. v. William E. Hooper \& Sons Co., 966 F.2d 837, 842 (4th Cir. 1992) (holding that parent would be liable as CERCLA "operator" if it had "authority to abate damage caused by" operations of contaminated facility); United States v. Kayser-Roth Corp., 910 F.2d 24, 26 (1st Cir. 1990) (holding that parent company that exercised pervasive control over subsidiary's contaminated textile plant was liable for cleanup costs as CERCLA "operator"); Idaho v. Bunker Hill Co., 635 F. Supp. 665, 672 (D. Idaho 1986) (holding that corporate liability depends on corporation's "capacity . . . to prevent and abate damage" from hazardous waste). But see Donahey v. Bogle, 129 F.3d 838, 843 (6th Cir. 1997) (finding that parent company would have CERCLA liability only when "circumstances justify piercing the corporate veil"), vacated without opinion sub nom. Donahey v. Livingstone, 524 U.S. 924 (1998); Joslyn Mfg. Co. v. T.L. James \& Co., 893 F.2d 80, 81 (5th Cir. 1990) (holding that CERCLA imposes no liability on parent corporations apart from that imposed by traditional veil piercing doctrine).

266. Bestfoods, 524 U.S. at 61-62.

267. Id. at 62 .

268. Id. (ellipsis in original) (quoting William O. Douglas \& Carrol M. Shanks, Insulation from Liability through Subsidiary Corporations, 39 Yale L.J. 193, 196 (1929)). In some ways, Bestfoods is even more protective of a parent company's prerogatives than earlier Supreme Court rulings. See, e.g., Chicago, Milwaukee \& St. Paul Ry. Co. v. Minneapolis Civic \& Commerce Ass'n, 247 U.S. 490, 497-98, 501 (1918) (relying in part on duplication of directors and officers to justify veil piercing).

269. Bestfoods, 524 U.S. at 62. 
So what was the fate of "direct" liability under this federal statute? The Court reasoned that it applied only to a parent corporation that engaged directly in "operations having to do with the leakage or disposal of hazardous waste, or decisions about compliance with environmental regulations."270 Thus, even though the subsidiary's operations consisted solely of running a single chemical manufacturing facility, and the district court found that the parent exercised "significant control" over the subsidiary's "business and decision-making," the Court found that mere involvement in and control over the subsidiary's operations could not expose the parent to CERCLA liability because it would be inconsistent with "common-law standards of limited liability."271

And, critically, the Court held that a parent company action that could be characterized as a "normal" part of the relationship with the subsidiary could not expose the parent to liability under CERCLA, even if the parent's action related to a hazardous waste disposal decision or compliance with the environmental laws. "[N]orms of corporate behavior," in the words of the Court, were to continue to serve as "reference points," notwithstanding this far-reaching environmental statute. ${ }^{272}$ Excluded from the "norms" of acceptable behavior are only the limited set of shareholder behaviors that might lead a court to pierce the corporate veil.

Thus, the Court reinterpreted CERCLA to create a safe harbor from federal statutory liability for parent corporations. That safe harbor was directly informed by current veil piercing rules. If a parent could exercise control over a subsidiary without risking limited liability under current veil piercing rules, that same behavior would provide a shield from statutory liability.

In view of its application of the federal statute most often identified as working a change in the rules of corporate shareholder liability, Bestfoods strongly suggests that statutory law imposing direct liability is unlikely to substantially broaden responsibility for corporate shareholders. ${ }^{273}$ These types of statutes consequently are unlikely to be a very effec-

270. Id. at $66-67$.

27I. Id. at $67-70$.

272. Id. at 7I. The Court held that a parent company could be held to have "operate[d]" a facility when it "depart[ed] so far from the norms of parental influence exercised through dual officelolding as to serve the parent, even when ostensibly acting on behalf of the subsidiary in operating the facility," or when an "agent of the parent with no hat to wear but the parent's hat might manage or direct activities at the facility." Id. In this case, the Court observed, there might have been such an employee-an employee who worked only for the parent but became directly involved in the subsidiary's environmental decisionmaking. Id.

273. Lower court cases decided after Bestfoods have continued to find that parent corporation control "within the parameters of normal oversight"-short of the required showing of control to justify veil piercing-is inmune from CERCLA liability. Datron, Inc. v. CRA Holdings, Inc., 42 F. Supp. 2d 736, 748 (W.D. Mich. I999); see also Schiavone v. Pearce, 77 F. Supp. 2d 284, 290-93 (D. Conn. I999) (holding that intertwined management and parent company approval of capital budget expenditures, including 
tive substitute for a direct change to vicarious liability rules for corporate shareholders and parents.

4. Fraudulent Conveyance Law. - Current fraudulent conveyance law also is unlikely to provide significant protection for tort victims injured by a corporate activity that presents excessive risks. A corporation may know it is engaged in risky activity that could expose it, somewhere down the line, to the possibility of substantial tort liability. For example, a pharmaceutical manufacturing operation may know that one of its products could present a risk of serious side effects. The corporation may even have general knowledge, given the size of typical jury awards for defective products, that if it is held liable in tort for the side effects, the corporation and its shareholders may not fully bear the costs. Even with this information, a corporation may, for example, pay contract claims and distribute dividends to its shareholders if the corporation is still solvent afterwards-even if the corporation ultimately may be left with insufficient assets to pay a particular plaintiff's claim.

Until a corporation has actual knowledge that a specific lawsuit is threatened or pending, a plaintiff will have a difficult time showing that the transfer was made with knowledge that a lawsuit has been filed or threatened, ${ }^{274}$ and hence "with actual intent to hinder, delay, or defraud any creditor." 275

Consider a corporate subsidiary that engages in environmentally risky activity by, for example, discharging wastewater that contains small amounts of hazardous chemicals, but that also regularly pays substantial dividends to its parent and pays its contract claimants. A downstream neighbor later discovers that the chemicals have affected her plant nurs-

expenditures on pollution control equipment, did not render parent company directly liable under CERCLA for cleanup of subsidiary's creosote plant).

274. See Uniform Fraudulent Transfer Act $\$ 4$ (b) (4), 7A U.L.A. 301-2 (1999). The UFTA has been adopted in tbirty-eight states and the District of Columbia, and its predecessor, the Uniform Fraudulent Conveyance Act, bas been adopted in four states and the Virgin Islands.

275. Id. $\S 4(\mathrm{a})$ (1). A plaintiff may also be able to show a fraudulent conveyance if the debtor was engaged in a business and had "unreasonably small" assets or reasonably should bave believed that the business would incur debts beyond its ability to pay as they became due, if the debtor made the conveyance "without receiving a reasonably equivalent value in exchange for the transfer or obligation." Id. \$4(a)(2). A showing that a corporation satisfied a bona fide contract claim, for example, is unlikely to satisfy this latter element, since the corporation will have received "reasonable equivalent value" in the form of the services rendered in the contract. Similarly, the preference to pay a dividend rather than to retain earnings in anticipation of potential future liability from risky activity is higbly unlikely to constitute a fraudulent conveyance, if the dividend payment does not render the corporation insolvent. See, e.g., Prairie Lakes Health Care Sys., Inc. v. Wookey, 583 N.W.2d 405, 413 (S.D. 1998) (noting that for conveyance to be fraudulent under section 5 of the UFTA, creditor's claim must arise before conveyance is made); Burke v. Marlboro Awning Co., 113 N.E.2d 222, 226 (Mass. 1953) (stating that, in context of dividend payments, "a mere preference is ordinarily not a fraudulent conveyance"). As James J. White has noted, asset sales for "reasonable equivalent value" also are not voidable under section 4 of the Uniform Fraudulent Transfer Act. White, supra note 50, at 1405. 
ery business and that the subsidiary does not have sufficient assets to fully address the pollution.

Although the amounts the corporation has paid in dividends and to the contract claimants would help compensate the neighbor, if they were made available to her, the neighbor would have to overcome several obstacles to recover on a fraudulent conveyance theory. First, as a plaintiff, the tort victim would have difficulty proving that, at the time the transfer was made, the corporation had knowledge of or should have anticipated that her property or business would be injured by the effluent. ${ }^{276}$ The corporation's knowledge that it was engaged in behavior that could present an environmental risk is unlikely to suffice. Second, the plaintiff may have an even more difficult time showing that the corporation knew or should have known the tort claimant's identity. Finally, even if the plaintiff could show that the corporation should have known that its discharge of hazardous chemicals would harm her property, leading to an actionable tort claim, courts generally will sustain a debtor's ability to transfer assets to legitimate creditors, even when the result is that the debtor lacks sufficient assets to fully satisfy the later tort judgment. ${ }^{277} \mathrm{ln}$ short, fraudulent conveyance law is unlikely to be of much assistance.

5. Free Transferability of Shares in Publicly-Traded Corporations. - Other commentators have argued that the free transferability of public corporation shares serves as another disincentive to overly risky projects. Because shares can be freely transferred, management teams selecting inappropriate projects arguably can be replaced through corporate takeovers. 278 Shares generally are not freely transferable where the corporation is a close corporation, however, or where it is a wholly- or mostly-owned sub-

276. Dickinson y. Ronwin, 935 S.W.2d 358, 364-65 (Mo. Ct. App. 1996) (invalidating transfer to close family friend on eve of tort judgment and citing George v. Surkamp, 76 S.W.2d 368, 370-71 (Mo. 1934), for proposition that "[c] onveyances made for the purpose of defeating an anticipated judgment in a case pending or about to be commenced are in fraud of creditors and void as to such plaintiff").

277. See Wyzard v. Goller, 28 Cal. Rptr. 2d 608, 610 (Ct. App. 1994) (citing Civil Code section 3432 for proposition that "[a] debtor may pay one creditor in preference to another, or may give to one creditor security for the payment of his demand in preference to another"); Smith v. Whitman, 189 A.2d 15, 18 (N.J. 1963) (stating that debtors can choose to pay one creditor over another). In Wyzard, the debtor's preferential transfer of assets to pay an attorney's bill for representation in a lawsuit was not held to be a fraudulent conveyance, even though it was apparent that the debtor likely would lose the lawsuit and that, if the judgment creditor executed on the judgment, the debtor might not have sufficient assets to pay the attorney's fee. $28 \mathrm{Cal}$. Rptr. at 612; see also Garton v. Garton, 533 N.W.2d 828, 833-34 (Iowa 1995) (finding that debtor's transfer of inheritance to pay debt to bank was not a fraudulent conveyance, even though it rendered him unable to pay spousal support and child maintenance obligations).

278. Easterbrook \& Fischel, Limited Liability, supra note 6, at 95-96; see Demsetz, supra note 47, at 387 (explaining that shareholders may engage in "a takeover, a rebellion by a group of cooperating shareholders, or the acquisition of large shareholdings" to "give proper guidance to, perhaps to 'boot' out, an ineffective management"). But see Goshen, supra note 188, at 884 (noting that market for corporate control, or the takeover market, offers only "indirect and expensive" discipline of management). 
sidiary. Even for publicly-traded companies, controlling shares are typically purchased at a significant premium. ${ }^{279}$ Moreover, a project that is socially inappropriate because of its expected cost might well be favored by shareholders because limited liability may subsidize those costs. So shareholders may not be the ones who will wish to discourage such projects. This argument would have significant force only if tort victims could help displace corporate managers. ${ }^{280}$

\section{A Control-Based Shareholder Liability Regime}

\section{A. The Capacity to Control Rule Proposed}

In general, legal structures and rules fail to fully address the problems flowing from limited liability. Moreover, the justifications for limited liability are largely confined to the case of the small, passive shareholder with no ability to control corporate direction. Meanwhile, the advantages of limited liability can be substantial for controlling shareholders.

A control-based regime would respond to these concerns. Such a regime would impose liability for a corporation's torts or statutory violations on a shareholder (including a corporate parent) when the shareholder has the "capacity to control" the corporation by virtue of ownership. ${ }^{281}$ To the extent more than one shareholder can be said to possess the "capacity to control," each would be jointly liable, with a right of contribution. Such a change could be accomplished by a liberalization of the

279. See Frank H. Easterbrook \& Daniel R. Fischel, Corporate Control Transactions, 91 Yale L.J. 698, 705 (1982) (noting that sale of a control block of stock will be at a "premium over the market price"); see also Herman, supra note 193, at 29 ("control is valuable and will be sought and consolidated"); Henry G. Manne, Our Two Corporation Systems: Law and Economics, 53 Va. L. Rev. 259, 279 (1967) (observing that in close corporations, "restrictions on share transferability are very common").

280. On occasion, social activists will purchase shares of a corporation so that they can attempt to participate in its governance and urge it to select activities that are less socially costly. However, these efforts have been few and remain the exception rather than the rule. They generally have not succeeded in significantly budging management that is otherwise committed to a certain course of conduct. E.g., Elizabeth Kolbert, In PCB Fight, It's the Nun vs. the C.E.O., N.Y. Times, May 25, 1998, at Bl (describing Sister Patricia Daly's unsuccessful effort to pass General Electric shareholders' resolution against various corporate efforts to resist cleaning up PCBs dumped into New York State's Hudson River); Watchdogs of Corporate Ethics, N.Y. Times, Mar. 5, 1981, at D1 (describing church group efforts to question Rockwell lnternational's nuclear weapons production, among other corporation policies). Kent Greenfield argues that shareholder power to enjoin a corporation's illegal acts as ultra vires should be viewed more expansively. Kent Greenfield, Ultra Vires Lives! A Stakeholder Analysis of Corporate Illegality (with Notes on How Corporate Law Could Reinforce International Law Norms), 87 Va. L. Rev. 1279, 1330-32 (2001).

281. A corporate officer, such as the CEO, who also holds a small ownership stake in the company as a performance incentive, would not have the "capacity to control by virtue of ownership." A similar standard is imposed under the "controlling persons" portions of the Securities Acts. See supra note 263. 
common law rule of veil piercing or through a statutory modification of the rules of vicarious liability. ${ }^{282}$

The rule would not impose responsibility on the shareholder that holds only a small percentage of shares. For the individual who purchased two hundred shares of General Motors on the open market, limited liability would remain a feature of the investment. Nor would the rule impose responsibility on the pension fund with a small percentage of shares.

How could one tell if a particular shareholder possessed the "capacity to control" a corporation? A shareholder would be responsible if it possessed significant ownership and if it exercised "actual control" over a corporation's activities by virtue of that ownership. Exercise of "actual control" over even some aspects of corporate operations would be relevant to the question of whether the shareholder possessed the "capacity to control" the risky activity, even if the actual control was unrelated to the operations that resulted in a tort or statutory violation. The exercise of actual control by virtue of ownership suggests the ability to control the corporation in other respects, either by involvement in the selection of the corporation's board of directors, the exercise of authority over significant asset sales, or participation in other major corporate decisions. ${ }^{283}$

For example, in In re Pollution Abatement Services, which dealt with a close corporation's liability for discharging refuse into and storing thousands of drums of chemicals on the banks of a creek, the two (of four total) shareholders that ran the corporation's day-to-day operations would have had vicarious responsibility under a control-based regime for the costs of cleaning up the chemicals if the shareholders had possessed potential control by virtue of their ownership. ${ }^{284}$ Such vicarious liability would have been in addition to whatever direct responsibility the shareholders might have had by virtue of their own actions. ${ }^{285}$ ln Ventron, for example, where the subsidiary's mercury processing operations substantially polluted a waterway, such a rule would have resulted in vicarious environmental liability for the parent company, which owned $100 \%$ of the subsidiary and which elected its own officers to the subsidiary's board of directors, where the board met monthly and knew the details of daily operations.

In addition to imposing liability on shareholders exercising actual control over a corporation by virtue of ownership, a "capacity to control"

282. Whether such a step would best be taken at the state or federal level is beyond the scope of this Article. Aside from the difficulty of convincing all fifty states to change their laws, Janet Cooper Alexander convincingly argues that claimants attempting to invoke expanded vicarious liability under state law would be beset by countless procedural difficulties. Cooper Alexander, supra note 11, at 388-89.

283. See Herman, supra note 193, at 26 ("[T] he dominant owners occupy the top offices themselves, or they select (and can readily displace) those who do.").

284. 763 F.2d 133, 135 (2d Cir.'1985).

285. In Pollution Abatement Services, for example, the court did impose direct liability on the shareholders under the Rivers and Harbors Act. Id. 
regime also would impose vicarious liability for a corporation's torts and statutory violations on those possessing potential control by virtue of ownership in the corporation. A potentially controlling shareholder's attempt to maintain a more passive role would not shield it from liability for risky corporate activity.

A majority shareholder clearly would qualify as possessing potential control by virtue of ownership. For shareholders holding less than a majority of the outstanding shares, whether the shareholder has the "capacity to control" the corporation would have to be decided based on the facts of the individual case. The American Law Institute takes the position that a controlling influence should be assumed where there is ownership and/or possession of the power to vote more than $25 \%$ of the corporation's shares. ${ }^{286}$ The SEC has publicly noted the "widely held belief that the ownership of $20 \%$ voting power in a widely held company in most instances constitutes control."287 However, the question whether a particular shareholder has the capacity to "direct . . . the management and policies of a [corporation]" 288 could in some cases be an issue requiring expert testimony. ${ }^{289}$

Whether a particular minority shareholder has the capacity to control the corporation might depend on the total value of the corporation and consequently the value of the shareholder's holdings; whether there is a majority shareholder; the relationship between the minority shareholder and that shareholder or other minority shareholders; or the relationship between that shareholder's board representatives and those of the other shareholders. ${ }^{290}$ Evidence that the shareholder has asserted a significant role in corporate organization also might be relevant, although that alone would not be sufficient to find that the shareholder

286. Principles, supra note $199, \S 1.10(\mathrm{~b})$; see also lnvestment Company Act $\$ 2$ (a) (9), codified at 15 U.S.C. $\$ 80 a-2(a)(9)$ (1994) ("Any person who owns beneficially ... more than 25 per centum of the voting securities of a company shall be presumed to control such company."); Essex Universal Corp. v. Yates, 305 F.2d 572, 579 (2d Cir. 1962) (stating that $28.3 \%$ owner is "almost certain to have share control as a practical matter").

287. Exchange Act Release No. 27,035, 54 Fed. Reg. 30,490, 30,492 n.23 (July 14, 1989), cited in Black, Shareholder Passivity, supra note 69, at 549 n.90. Although it is considered an aggressive position, the SEC staff apparently also has argued that a shareholder should be considered "controlling," under some circumstances, with a $10 \%$ equity holding. Black, Shareholder Passivity, supra note 69, at 549; see also Victor Brudney, Equal Treatment of Shareholders in Corporate Distributions and Reorganizations, 71 Cal. L. Rev. 1072, $1073 \mathrm{n} .2$ (1983) ("The owner of $5 \%$ or $10 \%$ of the outstanding voting power may possess control."); DeMott, supra note 214, at 1135-37 (describing incidents at Datapoint, in which $15 \%$ stock ownership was apparently adequate to confer control).

288. This formulation appears in the securities regulations, 17 C.F.R. $\$ 230.405$ (2001).

289. See, e.g., Herman, supra note 193, at 63 (noting that relevant criteria might include ability to select outside directors and establishment of "power position").

290. See, e.g., id. at 62-63 (noting that in 1975, market value of the median-sized 5\% holding of the 200 largest corporations amounted to $\$ 38$ million). 
possessed the capacity to control by virtue of ownership. ${ }^{291}$ For example, a socially conscious shareholder with $0.1 \%$ of ownership that influences a corporate decision through advocacy at an annual meeting would not have the capacity to control by virtue of ownership. ${ }^{292}$ Similarly, suppose a pension fund with $8 \%$ of a company's shares affects-through advocacy or as a "swing vote"- the election of a corporate director. Because the capacity to control signifies the consistent ability to exert control over the corporation by virtue of ownership, such activity would not make a shareholder one with a "capacity to control."

By comparison, in Chicago, Milwaukee E St. Paul Railway Co. v. Minneapolis Civic and Commerce Ass'n, each of the two parent companies held exactly $50 \%$ of the subsidiary's shares. ${ }^{293}$ Although neither held a majority, they had a history of acting together to control the subsidiary's operations. Given the level of ownership and such a history, the proposed rule would make them liable for a subsidiary's tort or statutory violations. Similarly, where the three individual shareholders of a close corporation together composed $50 \%$ of the board of each of the corporation's subsidiaries, so that no decision could be made without their approval, the individuals would have the "capacity to control."294

Further, in the product liability litigation over breast implants, the two corporate shareholders clearly would have been responsible for the liability of the manufacturer Dow Corning Company. Dow Corning was an incorporated joint venture of Dow Chemical Company and Corning Inc. Dow Corning was formed originally for the specific purpose of developing commercial and industrial uses for silicone technology. ${ }^{295}$ Each of the two shareholders owned $50 \%$ of the company. While corporate formalities apparently were observed, ${ }^{296}$ both shareholders had substantial involvement in the management of Dow Corning. Dow Corning's board of directors was composed completely of current and former Dow and Corning officers and directors. ${ }^{297}$ Moreover, Dow and Corning collaborated with Dow Corning in silicone research and product development. For several decades, Dow Chemical conducted all the toxicological research on hazards associated with silicone products. ${ }^{298}$

291. See id. at 26.

292. See supra note 280 .

293. 247 U.S. 490, 501 (1918).

294. See, e.g., Plaskon Electronic Materials v. Allied-Signal, 904 F. Supp. 644, 648-49 (N.D. Ohio 1995).

295. See Dow Chemical Co. v. Mahlum, 970 P.2d 98, 103 (Nev. 1998).

296. The relationship between Dow Corning and its parent companies included features typical of an arms-length relationship-for example, the shareholders each lent money to the joint venture, but on terms advantageous to the joint venture. Further, there was no indication that Dow Corning paid exceptionally large dividends. See Deborah DeMott, The Mechanisms of Control, 13 Conn. J. Int'l L. 233, 242 (1999) ("Dow Corning's finances reflected a policy of retaining a relatively high percentage of earnings as opposed to distributing earnings as dividends.").

297. Id.

298. Dow Chemical, 970 P.2d at 104. 
In the face of multiple product liability claims relating to silicone breast implants, Dow Corning petitioned for bankruptcy in 1995. 299 However, the courts did not permit plaintiffs to reach the assets of either parent company under a veil piercing theory. ${ }^{300}$ Tort plaintiffs might have received more compensation if they had. ${ }^{301}$ Under a control-based

\section{See id. at 106.}

300. See, e.g., In re Silicone Gel Breast Implants Prods. Liab. Litig., 837 F. Supp. 1128, 1142 (N.D. Ala. 1993), (dismissing claims of vicarious liability against Dow and Corning in centralized federal multidistrict litigation), vacated in part, In re Silicone Gel Breast Implants Prods. Liab. Litig., 887 F. Supp. 1455 (N.D. Ala. 1995). In one case, however, Dow was held directly liable for negligent performance of an undertaking on the theory that Dow had directly undertaken to evaluate and test the safety of Dow Corning's liquid silicone and should have "used its influence to halt the marketing" of Dow Corning's silicone breast implants. Dow Chemical, 970 P.2d at 118; see also 887 F. Supp. at 1459-63 (refusing to dismiss claim, in multidistrict litigation, that Dow was directly liable for negligent undertaking and mentioning similar rulings in other courts). But see Artiglio v. Corning Inc., 957 P.2d 1313, 1318-19 (Cal. 1998) (refusing to hold either Dow or Corning liable on "negligent undertaking" theory).

301. For example, Dow Chemical, the larger of the two shareholders, is one of the nation's fifty largest companies and is worth multibillions of dollars. See, e.g., Woman Wins $\$ 14$ Million in Punitive Damages in Implant Case, Grand Rapids Press, Oct. 31, 1995, at A7 ("During a hearing on Dow Chemical's financial status, experts testified the Midland, Mich.-based firm is worth $\$ 8$ billion to $\$ 9$ billion.").

Conceivably, the holding discussed above finding Dow directly liable for negligent undertaking might have been extended to other plaintiffs. See supra note 300 . If so, even in the absence of vicarious liability, some tort plaintiffs might have received compensation from Dow. Further, Dow is making a contribution to compensating breast implant plaintiffs through the Dow Corning bankruptcy proceeding. Dow apparently has contributed to a $\$ 2.35$ billion fund that will pay to resolve the claims of consenting personal injury claimants, among others, and a litigation facility of $\$ 400$ million to address the claims of non-consenting personal injury plaintiffs, among others. See $1 n$ re Dow Corning Corp., 280 F.3d 648, 655 (6th Cir. 2002) (discussing fund created by Dow Corning and its product liability insurers and shareholders); In re Dow Corning Corp., 255 B.R. 445, 484 (E.D. Mich. 2000) (discussing size of litigation facility), aff'd, 280 F.3d 648 (6th Cir. 2002). Both funds are components of Dow Corning's bankruptcy reorganization plan. The quid pro quo for the contributions of Dow and Corning, however, is a permanent injunction, contained in the reorganization plan, preventing any party holding a claim released against Dow Corning from suing either Dow or Corning, and limiting plaintiffs to suing the litigation facility. In re Dow Corming Corp., 280 F.3d at 655 . In January, 2002, the Court of Appeals for the Sixth Circuit affirmed the conclusion below that a bankruptcy court may enjoin a non-consenting creditor's claim against a non-debtor to facilitate a reorganization plan, but remanded for further proceedings because the bankruptcy court's fact findings did not demonstrate the appropriateness of the injunction under the criteria set forth by the Sixth Circuit. See id. at 653.

Under a control-based liability rule, Dow and Corning could conceivably have procured similar treatment by a bankruptcy court. Further, it is possible that the amounts set aside by the bankruptcy court are adequate to fully compensate all the tort plaintiffs. If either of these conditions obtained, a control-based liability rule would make no difference. On the other hand, had tort plaintiffs been able to recover directly from Dow Chemical or from Corning, they might well have received more than they are likely to under the reorganization plan. In this regard, it is worth noting that an earlier $\$ 4.225$ billion global settlement, to which Dow Corning contributed approximately half the funds, and which was approved by a court overseeing a multidistrict litigation in 1994, collapsed 
liability rule, both Dow Chemical and Corning would have been considered shareholders with the "capacity to control" and would have had vicarious responsibility for Dow Corning's product liability for breast implants. ${ }^{302}$

For judges, the "capacity to control" standard would not be novel. In the context of cases under the Employee Retirement Income Security Act of I974 (ERISA), ${ }^{303}$ for example, courts must consider whether a pension fund fiduciary has purchased or sold certain assets for "fair market value." ${ }^{304}$ In order to determine whether a control premium should have been paid when a corporate ownership stake is acquired or sold, judges consider whether a controlling share was involved in the transaction. ${ }^{305}$

And, as discussed above, a shareholder that can control a corporation is responsible for its securities law violations. ${ }^{306}$ The SEC has interpreted the statutory language as the "power to direct ... the management

as apparently inadequate when "hundreds of thousands more women than anticipated filed claims with the global settlement fund." Id. at 653; see also In re Dow Corming Corp., 255 B.R. at 462 ("Based on the number of claims filed, the claimants would have received only a small percentage of what was previously promised. Some estimated that the defendant manufacturers [which included Dow Corning] would have had to jointly contribute another $\$ 24$ billion to the settlement fund to pay all the claimants the amount promised.").

302. The argument has been made that the breast implant tort judgments were not based on the soundest of scientific evidence. See, e.g., Mike McKee, Junk Science Debate Rages On, Legal Times, Mar. 22, 1999, at 2 (quoting Dr. Marcia Angell, editor of the New England Journal of Medicine, as saying that many breast implant plaintiffs got "big bucks" by using purported expert witnesses who often merely added "a veneer to a foregone conclusion"). Even if true, however, that would not warrant a different shareholder liability rule. Arguments about flaws in the tort system should be addressed directly. See infra note 367 .

\section{29 U.S.C. $\$ \$ 1001-1461$ (1994 \& Supp. V 1999).}

304. E.g., id. $\$ 1108(\mathrm{e})$ (stating that fiduciary may purchase ESOP securities for "adequate consideration"); id. $\$ 1002(18)$ (defining "adequate consideration" to mean fair market value).

305. See, e.g., Montgomery v. Aetna Plywood, lnc., 39 F. Supp. 2d 915, 931 (N.D. Ill. 1998) (calculating control premium for sale of interest in privately-held corporation). The Montgomery court relied on a proposed ERISA regulation, 53 Fed. Reg. 17,632, 17,636 (May 17,1988 ), suggesting that "fair market value" should include the calculation of a control premium if such a premium would be paid by a third party with regard to the securities being valued, if control would pass with the equity being purchased, and if it is reasonable to assume that the purchaser's control will not be shortly dissipated. Id.

306. See 15 U.S.C. $\$ 77$ o (1994) ("Every person who, by or through stock ownership . . controls any person liable under [section $77 \mathrm{k}$ or section $77 \mathrm{l}$ ] shall also be liable jointly and severally with and to the same extent as such controlled person."); id. \$ 78t(a) ("Every person who, directly or indirectly, controls any person liable . . . shall also be liable jointly and severally with [that person]."). 


\section{and policies of a person." 307 Several courts have taken similar positions. ${ }^{308}$}

Further, in the context of determining when a parent company might have CERCLA liability for "operating" the facility of a subsidiary where a hazardous substance has been released, a number of courts, prior to the Bestfoods ruling, imposed liability when the entity had "authority to control" the operations of the contaminated facility or decisions involving hazardous substance disposal. For example, in Nurad, Inc. v. William E. Hooper $\mathcal{E}^{2}$ Sons Co. ${ }^{309}$ the Fourth Circuit ruled that an en-

307. Securities Act Rule 504, 17 C.F.R. \$ 230.405 (2001); Securities Exchange Act Rule 12b-2, 17 C.F.R. $§ 240.12 b-2$ (2001). See generally Black, Shareholder Passivity, supra note 69 , at 548 (discussing controlling persons' liability).

308. A number of courts have held that a person is a "controlling person" based on a showing of the person's voting authority as a shareholder, sometimes coupled with the person's position within the corporate organization. For example, in G.A. Thompson E Co. v. Partridge, the Fifth Circuit held that a $24 \%$ shareholder, who had an officership and directorship and who was involved in day-to-day operations, had the "requisite power to directly or indirectly control or influence corporate policy," even though the shareholder had not actually participated in the securities violation at issue. 636 F.2d 945, 958 \& n.24 (5th Cir. 1981). And in First Interstate Bank of Denver, N.A. v. Pring, the court overturned a district court's grant of summary judgment to a defendant that was a $20 \%$ stockholder of a general partner of a partnership that had violated securities laws. 969 F.2d 891, 898 (10th Cir. 1992), rev'd sub nom. on other grounds, Central Bank of Denver, N.A. v. First Interstate Bank of Denver, N.A., 511 U.S. 164 (1994). Together with his wife, he was a 35\% owner of the general partner; he also was a director and vice president of the general partners. Consequently, he was in a position of at least indirect control over the developer and its general partners, which in turn controlled the issuer of the bonds. Id. In Whirlpool Finance Corp. v. GN Holdings, Inc., the court refused to dismiss a securities law claim against a parent corporation and two shareholders that later controlled $51 \%$ of the corporate defendant, reasoning that the facts could expose the shareholders to "control person" liability under the securities laws. 873 F. Supp. 111, 121 (N.D. Ill. 1995), aff'd, 67 F.3d 605 (7th Cir. 1995); see also Donohoe v. Consol. Operating \& Prod. Corp., 982 F.2d 1130, 1139 (7th Cir. 1992) (finding that promoters of oil limited partnerships could be held liable as control persons under federal securities laws); Harrison v. Dean Witter Reynolds, Inc., 974 F.2d 873, 881 (7th Gir. 1992) (overturning summary judgment verdict for defendant because fact issue existed as to whether broker-dealer was liable as controlling person); Hunt v. Miller, 908 F.2d 1210, 1215 (4th Cir. 1990) (holding that evidence was sufficient to submit to jury the question of whether defendant was liable for securities fraud as controlling person, arising from sale of partnership interests in real estate venture); Drier v. Tarpon Oil Co., 522 F.2d 199, 200 (5th Cir. 1975) (holding that $78 \%$ shareholder and president could be "control person"); Harriman v. E.I. DuPont De Nemours \& Co., 372 F. Supp. 101, 105 (D. Del. 1974) (rejecting trust company's motion to dismiss for failure to state a claim, thereby allowing plaintiff to state a cause of action against a controlling person without alleging any affirmative action on its part). But see Sharp v. Coopers \& Lybrand, 649 F.2d 175, 185 (3d Cir. 1981) (holding that section 20 (a) requires "culpable participation' in the securities violation").

309. 966 F.2d 837, 842 (4th Cir. 1992). Other opinions applying a similar standard include Vermont v. Staco, Inc., 684 F. Supp. 822, 835 (D. Vt. 1988) (imposing liability for cleaning up waste under Resource Conservation and Recovery Act, 42 U.S.C. $\$ 6972(\mathrm{a})(1)$ (B) (1994), upon individual defendants that were "in a position as a corporate office or major stockholder, to have 'ultimate authority to control' the proper handling of mercury at the Staco plant"); Idaho v. Bunker Hill Co., 635 F. Supp. 665, 672 
tity's "authority to control" a contaminated facility or hazardous substance disposal decision would lead to "operator" liability under CERCLA. ${ }^{310}$

Under a control-based regime of vicarious tort liability for corporate shareholders, a court's conclusion that a parent company possessed the capacity to control the subsidiary would render the parent jointly and severally liable, with a right of contribution, with the corporation and any other shareholders possessing the capacity to control. In holding a shareholder fully responsible, a control-based regime is similar to current veil piercing rules. Once a veil is pierced under current law, the defendant shareholder's responsibility for the corporation's obligations is also complete. ${ }^{311}$

A question remains regarding the time when shareholder liability would be assessed. There are essentially three choices: an "occurrence" rule, imposing liability on a shareholder with the capacity to control the corporation at the time of the occurrence that leads to liability in excess of corporate assets; a "claims-made" rule, attaching liability to persons who are controlling shareholders at the time they receive notice that a claim will be filed against the corporation; and a "judgment" rule, attaching liability to those that are controlling shareholders at the time of judgment.

An "occurrence" rule would appropriately encourage those in positions of control to monitor and influence corporate decisionmaking. Among the three timing rules, it would best minimize the opportunity for a shareholder to evade liability by selling its shares immediately after the occurrence. $^{312}$ ln proposing a pro rata regime, Hansmann and Kraakman reject an occurrence-based rule in favor of a modified form of a

(D. Idaho 1986) (holding that parent corporation is owner or operator under CERCLA if it has capacity to discover and/or prevent and abate the discharge); see also United States v. Nicolet, Inc., 712 F. Supp. 1193, 1202 (E.D. Pa. 1989) (refusing to dismiss CERCLA claim against parent of wholly-owned asbestos manufacturing subsidiary, despite lack of evidence of control over disposal operations, in view of "substantial financial or ownership interest in the subsidiary"; control over "management and operations"; and "capacity to control" waste disposal practices).

310. The defendants in Nurad included prior tenants and two vice presidents of a company; the Fourth Circuit found them not liable because they lacked the "authority to control." 966 F.2d at 842, 844. Although Nurad did not involve a parent corporation or majority shareholder, the holding has been interpreted to apply to such parties. E.g., United States v. Bestfoods, 524 U.S. 51, $60 \mathrm{n} .8$ (citing Nurad for proposition that "parent having authority to control subsidiary is liable as an operator, even if it did not exercise that authority"); see also 40 C.F.R. $\$ 89.2$ (2001) (defining nonroad vehicle or equipment manufacturer to include "[a] 11 nonroad vehicle or equipment manufacturing entities that are under the control of the same person").

311. If there are multiple "controlling shareholders," they would be jointly and severally liable for a single corporate tort.

3I2. It would also address the concern, expressed by Easterbrook and Fischel, that an expanded shareholder liability rule would deter beneficial control transactions because a new buyer would wish to avoid the risk of having to contribute to already existing debts. Easterbrook \& Fischel, Economic Structure, supra note 6, at 43. 
claims-made rule. ${ }^{313}$ They argue that when a corporate tort spans a period of time, determining when the tort "happened" and which shareholders are liable will present significant administrative difficulties because of the number of involved shareholders and the prospect that shares could have changed hands. ${ }^{314}$

These administrative difficulties would be considerably reduced under a control-based regime because fewer shareholders would be involved. Although some torts might take place over a long period of time (as they presently do), and controlling shares could change hands during that period, similar apportionment issues have proved manageable for courts. For example, courts have had to apportion liability among different corporate defendants when a manufacturing operation's activities have created statutory liability and the operation has changed hands during the activities in question. ${ }^{315}$

Another potential issue would be the conflict of interest between shareholders at the time a lawsuit is filed and "old" controlling shareholders that may have liability if a judgment exceeds corporate assets, but that no longer hold shares in the firm. New shareholders might be tempted, for example, to distribute or otherwise dissipate corporate assets to reduce the assets available to pay a judgment, thus shifting the liability costs to the old shareholders. This conflict of interest would be heightened under an occurrence-based rule, simply because the greater the length of time between the occurrence of the tort and the issuance of a judgment, the more likely it will be that shares will have changed hands. To the extent that fraudulent conveyance law does not address this concern, Hansmann and Kraakman correctly argue that any adequate regime of expanded shareholder liability must include a "duty on management to avoid opportunism on the part of new shareholders."316

\section{B. Comparison of a Control-Based Regime with Other Regimes}

In their proposal for a regime of unlimited pro rata liability, Hansmann and Kraakman argue that there are "no persuasive reasons" to prefer a regime of limited liability over their proposed regime. ${ }^{317}$ They also argue that pro rata liability for all corporate shareholders is feasible, even for shares traded on public stock exchanges. ${ }^{318}$

313. Hansmann \& Kraakman, Unlimited Liability, supra note 2, at 1896.

314. Id. at 1897.

315. See, e.g., 1n re Bell Petroleum Serv., Inc., 3 F.3d 889, 903-04 (5th Cir. 1993) (apportioning environmental cleanup liability among former site owners); Cent. Me. Power Co. v. F.J. O'Connor Co., 838 F. Supp. 641 (D. Me. 1993) (apportioning environmental cleanup liability among current and former site owners and companies that had disposed of scrap at site).

316. Hansmann \& Kraakman, Unlimited Liability, supra note 2, at 1899.

317. 1d. at 1880.

318. 1d. at 1895-99. 
A definitive choice of the "best" shareholder liability regime depends at least somewhat on a number of empirical issues, including insurance availability and the precise distribution of corporate ownership. Nonetheless, a comparison of the limited liability regime, a pro rata liability regime, and a control-based liability regime suggests that a control-based regime is a strong contender as a solution to the problem of limited liability's moral hazard. And, depending on the results of empirical investigation, it might indeed prove superior.

The following analysis compares the three regimes in several ways. First, in terms of ensuring that those benefiting from risky corporate activity internalize the costs of those activities, both a control-based regime and a pro rata regime are clearly superior to a limited liability regime. As between the last two, a control-based regime appears superior to a pro rata regime because controlling shareholders will face inadequate incentives to internalize costs under a pro rata regime. Second, compared to a control-based regime, a pro rata regime likely will impose greater litigation costs upon a plaintiff seeking compensation for risky corporate activity. This will reduce the ability of corporate tort victims to receive compensation. To the extent plaintiffs do overcome the litigation costs barrier and seek compensation from, among others, very small corporate shareholders, a pro rata regime may encourage those shareholders to engage in relatively costly monitoring.

On the other hand, a control-based regime also has weaknesses. ${ }^{319}$ Some asserted weaknesses are common to any regime that imposes greater liability on shareholders, including the pro rata liability regime. Assertions specific to a control-based regime include: the prospect of in-

319. In a world without transaction costs, the most efficient solution to the problem of internalizing costs may be to apportion the costs of a corporate activity in proportion to the shareholders' expected benefit. That would mean adding a premium or discounting each shareholder's right to receive dividends depending on the shareholder's ability to control the corporation. If there were no transaction costs, shares would be tradable because investors could costlessly monitor each others' holdings and wealth. Further, each shareholder would face incentives that, to the extent of current tort and statutory law, correctly internalize social costs and benefits.

Such a rule is unworkable, however, due to the existence of transaction costs. First, it would be more difficult to trade minority shares, because the value of each share would depend on, among other things, the ownership distribution of the remaining shares. Second, transaction costs could prevent a tort victim from collecting from numerous minority shareholders of a corporation, thus reducing compensation for injuries (and deterrence) from risky corporate activity. See, e.g., id. at 1899-1900 ("Very large collection costs ... would lower settlement values and hence reduce the deterrent effect of tort rules."). Further, calling on the court to add a premium to or discount each shareholder's responsibility depending on control considerations similarly would make judicial proceedings considerably more cumbersome. Given the reality of transaction costs, the control-based regime proposed here is more likely than either the "efficient rule" outlined above or a pro rata liability rule to ensure that a corporation and the shareholders that can control it more fully internalize costs of excessively risky operations. It is also more likely to assure compensation for tort victims and the environment. See supra note 192 (regarding theory of the second-best). 
creased costs from litigation over the meaning of the rule; the inability of a plaintiff to obtain compensation from excessively risky activity when a corporation has no shareholder with a capacity to control; overdeterrence of some socially beneficial activities when insurance is not available for the activity; and a change in equity ownership patterns.

1. Internalizing the Costs of Risky Activities. - Both the "capacity to control" regime and the pro rata regime purport to address limited liability's critical problem: the corporate ability to externalize the costs of risky activities and the resulting incentive to overinvest in those activities. As discussed below, a control-based regime is likely to be more successful than a pro rata regime in addressing limited liability's moral hazard.

Under a control-based liability regime, shareholders with the capacity to control, who can most cheaply monitor corporations, more often would encourage corporate management to resist risky, socially costly activities, to maintain appropriate operating reserves, and to insure against the potential costs of risky activities. ${ }^{320}$ Firms would more likely internalize their costs, rather than shift excess costs to involuntary creditors such as tort victims. Tort and statutory claimants would more likely be compensated.

Parent corporations and controlling shareholders would have no incentive to close their eyes to a corporation's risky business choices. ${ }^{321} \mathrm{~A}$ parent corporation with special knowledge or technology would be more likely to make it available to a subsidiary as a means of minimizing risk from the subsidiary's activities. ${ }^{322}$ A parent company could assist a subsidiary in locating liability insurance. Finally, a parent company would be more likely to direct its limited resources to reducing the risks presented by corporate activities, rather than attempting to avoid paying the costs of

320. See Stone, supra note 7 , at 73 . See also supra note 71 (observing that environmental insurance has become increasingly available).

321. Hansmann and Kraakman appear to argue that a reduction in control premiums-which could result from a control-based liability regime-would be related to a "decrease in shareholder monitoring of the management of risky firms." Hansmann \& Kraakman, Unlimited Liability, supra note 2, at 1905. This seems to assume that the number of firms engaged in risky activity will be the same, but that fewer investors will accumulate large holdings and have the incentive to monitor management closely. Another possibility is that the reduced investment in firms engaged in risky activity, together with greater expression of managerial risk aversion, will lead firms to move to less risky activities. To the extent there is inefficiency from reduced monitoring of management, it would be offset by reductions in firm investment in overly risky activity. Even leaving aside investment in overly risky activity, it is not altogether clear that more shareholder control is more efficient. See infra note 363 and accompanying text.

322. Cf. Shell Oil Co. v. Meyer, 684 N.E.2d 504, 516-17 (lnd. Ct. App. 1997) (holding franchiser, a large oil marketer, responsible for underground storage tank due to its knowledge of steel underground storage tank problems and fact that "the solution to the problem required significant engineering knowledge and resources beyond the limits of most gas station owners"), transfer granted, 698 N.E.2d 1183 (1998). 
those risks through corporate restructuring. ${ }^{323}$ Corporations would thus be less likely to select excessively risky corporate activities.

Of course, on the occasions when a corporate activity presents a risk that could not possibly be anticipated, ${ }^{324}$ a control-based shareholder liability rule could not realize this particular benefit. The shareholders would have no advantage over tort victims in anticipating risks. A controlbased shareholder liability rule then would contribute to efficiency if the controlling shareholders generally were better risk bearers than the tort victims. This seems likely. As discussed above, there seems no reason generally to conclude that tort victims would be better risk bearers than shareholders or controlling shareholders in particular. For example, a corporate or institutional controlling shareholder, such as a parent corporation, almost certainly will be a better bearer of risk than a tort victim, who is very likely to be an individual. ${ }^{325}$ Perhaps more important, a controlling shareholder likely can better spread risk than a tort victim because the shareholder can influence the corporation to buy insurance, and liability insurance is likely to be more readily available to the corporation than first-party insurance is to the individual tort victim. ${ }^{326}$

At an economy-wide level, one would expect to see an overall reduction in risky activities undertaken by corporations. Under any regime, control generally confers on the shareholder a greater expected benefit per share purchased, relative to other shareholders. ${ }^{327}$ Under a controlbased liability regime, control also would confer greater responsibility. An entity that purchased a controlling share of ownership in a highly risky corporate activity could expect to face higher costs should the risky business result in a tort liability judgment exceeding the corporation's assets. For corporations engaged in highly risky activity, especially activities presenting risks of extremely large injuries, one would expect to see a reduced demand for controlling shares and a decline in the premium paid for control. ${ }^{328}$ Overall, corporations would be less likely to select

323. See, e.g., Menell, supra note 123 , at 410-11 (contending that uncertainty of limited liability rules weighs in favor of counseling clients to adopt risk minimization strategy).

324. Schwartz, supra note 77 , at 691 .

325. See supra text accompanying notes $82-92$.

326. See supra text accompanying notes $90-92$. On the other hand, for some cases of truly unforeseeable risks, the effect of a control-based liability rule would be less clear. For example, suppose a corporate risk is truly unforeseeable and for some reason difficult to insure, the controlling shareholder is an individual shareholder; is risk averse; and the loss from the injury represents a large proportion of her wealth. Under these circumstances, the shareholder might not be a better risk bearer than a tort victim, especially if the tort victim is one of many and each victim would bear a cost representing a relatively small percentage of his or her portfolio.

327. See supra text accompanying notes 206-231 (discussing particular benefits attributable to shareholder control).

328. With a rule of pro rata liability, a similar consequence is likely. See Hansmann \& Kraakman, Unlimited Liability, supra note 2, at 1905 (observing that pro rata rule "clearly would increase a risk-averse investor's cost of accumulating a large holding in a risky 
risky activities, either because of the presence of a controlling shareholder with responsibility for tort or statutory liability or because, in the absence of such a shareholder, managers could more freely express their tendencies toward risk aversion.

Like a control-based liability regime, a pro rata liability regime would also encourage shareholder monitoring of corporate operations and reduce corporate externalization of the costs of risky activities. However, the pro rata regime's incentives for controlling shareholders are inadequate.

Under a pro rata regime, a controlling shareholder would face excess costs from risky corporate activity only in proportion to its share of corporate equity. However, the controlling shareholder can expect to receive more benefit from corporate activity than its pro rata ownership might suggest. ${ }^{329}$ Depending on the corporation's structure and operation, the benefit could substantially exceed the controlling shareholder's pro rata share. A controlling shareholder thus might find desirable risky activities that a shareholder without control would not, and the controlling shareholder might encourage corporate management to choose these activities.

A pro rata regime would tend to inadequately deter such a controlling shareholder from influencing a corporation to select excessively risky activity. Despite receiving control-specific benefits, such a shareholder or parent would, under the pro rata regime, bear responsibility for an excessively risky corporate activity only in proportion to the share of equity held. To the extent expected costs exceed corporate assets, the controlling shareholder thus would continue to receive some "discount" on expected liability from a risky corporate activity, although expected benefits would not be similarly discounted. The controlling shareholder thus likely would still encourage overinvestment in such activities, even for some activities for which the activity's social cost exceeds its social benefit.

More subtly, a controlling shareholder would have a reduced incentive to ensure that a corporation is appropriately capitalized or carries appropriate insurance in view of the expected costs of its activities. This is because under a pro rata regime, a controlling shareholder's share of expected costs from a risky activity would be higher if the corporation is fully insured or capitalized than if it is not.

Suppose a corporation buys more insurance. The controlling shareholder would likely bear more than a pro rata share of those costs in the form of reduced dividends and other benefits. For example, this could reduce the corporation's total cash flow, which could result not only in a reduction of dividends (borne on a pro rata basis), but in a reduction in tax advantages and an increase in the controlling shareholder's cost of

corporation relative to the investor's cost of holding a diversified portfolio" and takeover premiums for risky firms wotuld decline).

329. See supra text accompanying notes 206-231. 
capital. ${ }^{330}$ However, if the corporation were underinsured, the controlling shareholder's expected liability would be limited to a pro rata share of the expected loss in excess of insurance and assets. While incentives to insure adequately are surely greater under the pro rata regime than under a limited liability regime, a controlling shareholder still might encourage a corporation to underinsure its risky operations.

Further, the presence of litigation costs will render a pro rata rule less effective than a capacity to control rule in compelling a corporation with a controlling shareholder to internalize its costs. ${ }^{331}$ This will be the case even if the argument could be made that controlling shareholders do not realize any additional value from holding control of a corporation or, on the margin, from a particular corporate activity. Take a corporation that has a $51 \%$ shareholder and numerous small shareholders. As among all corporations, such a corporation is more likely to select excessively risky activities because of the presence of the majority shareholder. Under the pro rata liability regime, however, chances are good that a tort victim injured by the risky corporate activity would recoup only $51 \%$ of a tort liability judgment to the extent it exceeds corporate assets. As discussed in more detail below, obtaining additional recovery from investors that each own a tiny fraction of the total shares would involve considerable difficulty and expense. ${ }^{332}$ Tort victims might well forego this effort. As discussed above, a considerable number of publicly-held corporations potentially fit this model. ${ }^{333}$ Consequently, tort and statutory claimants would continue to bear some or all of those costs, rather than be fully compensated.

Even assuming that there is no particular benefit to control, controlling shareholders would still obtain some benefits (distributed pro rata) from the corporation's collective ability to externalize costs as a result of the transaction costs faced by plaintiffs. As a consequence, controlling shareholders still would have an incentive to encourage corporations to overinvest in risky activity.

Hansmann and Kraakman acknowledge that under their regime, the damages owed to tort victims from risky corporate activity likely would not be fully paid, despite adequate shareholder assets, because of collec-

330. See supra text accompanying note 223.

331. Cf. Cooper Alexander, supra note 11, at 389 ("The feasibility and costs of implementing a substantive rule are critical to evaluating what it would actually accomplish, and whether it would be an improvement over existing laws or possible alternatives.").

332. E.g., Stone, supra note 7, at 75 ("In tbe typical giant, publicly held enterprise ... no ordinary investor's exposure would be more than nominal."). Of course, this problem will not be as severe for closely-held corporations, since they generally have many fewer shareholders. Further, to the extent the shares of a public corporation are concentrated in the hands of a few institutional shareholders, this problem will be less serious. But see supra note 46 (noting that 500 shareholders at minimum are needed for NYSE listing).

333. See supra text accompanying note 47 (citing Demsetz conclusion that approximately $50 \%$ of publicly-traded companies are "owner-controlled"). 
tion difficulties. ${ }^{334}$ They argue that public corporations nonetheless would bear the "bulk of their expected liability costs." 335

This would seem to be true primarily when a nonpublicly-traded subsidiary or close corporation is, say, $95 \%$ or more owned by the parent. The shareholder or parent would be almost completely responsible for judgments that exceeded the assets of the corporation. ${ }^{336}$ When a significant part of a corporation's equity is held by numerous small shareholders, however, a tort victim seeking compensation in excess of corporate assets under a pro rata liability regime would be unlikely to recover the bulk of her damages. Such a firm still could externalize significant costs of its activities.

This problem would be most significant for a corporation whose shareholders include at least one with capacity to control and a large number of additional shareholders. Transaction costs would hinder a plaintiff's efforts to obtain full compensation from shareholders. Meanwhile, the controlling shareholder would be encouraging excessively risky activities. As discussed above, this equity distribution profile may be typical of a significant percentage of publicly-traded corporations. ${ }^{337}$

By comparison, under a control-based regime, a tort victim could seek full recourse from the majority or controlling shareholder. The controlling shareholder would be unlikely to prompt management to externalize costs. The corporation and its shareholders would be more likely to internalize the costs of their risky activity and to compensate the tort or statutory claimant.

2. Incentives to Insure. - As mentioned in the previous section, a controlling shareholder would have an incentive, under a pro rata regime, to encourage a corporation engaged in risky activity to underinsure. Under such a regime, a controlling shareholder would be likely to bear a greater share of corporate investments in insurance or capital than the shareholder would bear if a court actually imposed liability in excess of what the corporation could pay.

By comparison, under a control-based regime, a controlling shareholder would be more likely to make sure that the corporation has in-

334. See Hansmann \& Kraakman, Unlimited Liability, supra note 2, at 1901.

335. Id. For the privately-held corporation with a small number of shareholders, a plaintiff seeking to invoke a pro rata liability rule probably will face manageable transaction costs.

336. Under a pro rata regime, a well-capitalized public corporation would likely bear the bulk of its expected liability costs, just as it does under the current limited liability regime. Once it decided it was willing to pay its subsidiary's liabilities, for example, the Exxon Corporation's payment of liabilities arising out of the Exxon Valdez oil spill put a dent in revenues for only one year. See supra note 162 and accompanying text.

337. See supra text accompanying note 48 (discussing 1988 survey identifying 650 public corporations with majority shareholders); supra text accompanying note 47 (discussing Demsetz data). To be listed on a public stock exchange, company shareholders must generally number in the hundreds. See supra note 46 (noting that minimum of 500 sharebolders is needed for NYSE listing). 
sured adequately, given the risks presented by a particular activity. If a corporation were adequately capitalized or adequately insured for the risky activities it undertook, the controlling shareholder would share the expected costs of a particular activity with other shareholders in the same proportion as it would share the benefits of corporate activities. The controlling shareholder's expected costs likely would consist of reduced dividends and other expected benefits of share ownership, such as reduced tax benefits or synergy opportunities. Failure to ensure that a corporation is adequately capitalized or insured would expose the controlling shareholder to a larger proportion of liability for costs exceeding corporate assets. ${ }^{338}$ In comparison to both the limited liability and pro rata regimes, the controlling shareholder thus would be more likely to ensure that a corporation is adequately capitalized or insured.

3. Litigation and Transaction Costs. - Because fewer parties would be involved in litigation, a control-based liability regime also would tend to minimize litigation and transaction costs. Under a pro rata regime, a tort plaintiff interested in full compensation would have to engage in the costly enterprise of naming all shareholders as defendants-including identifying, locating, and serving these defendants. ${ }^{339}$ Especially for a publicly-held corporation with a controlling shareholder holding substantially less than all the shares, the number of potential defendants could be numerous. ${ }^{340}$ In comparison, a tort plaintiff in a control-based liability regime could name many fewer shareholders to obtain recovery for an injury caused by corporate activity.

To the extent they do risk a lawsuit, small shareholders also could incur significant transaction costs under a pro rata unlimited liability regime, relative to a control-based regime. Because of a prospective plaintiff's substantial transaction costs, a small shareholder could discount the

338. Some risks, of course, might be uninsurable. Under these circumstances, a controlling shareholder might simply avoid a risky activity. See infra text accompanying notes $364-367$.

339. For the difficulties facing a plaintiff who wishes to pursue numerous corporate shareholders under a pro rata liability rule implemented through state tort law, see generally Cooper Alexander, supra note 11, at 421-24 ("Thus, [pro rata] unlimited liability would not normally be implemented in a unified proceeding in a single court, but rather in many different proceedings in many courts, possibly occurring long after the initial tort suit or suits are filed.").

Shareholders could be required to bear litigation costs. This clearly would enable tort plaintiffs to obtain more compensation under a pro rata rule. However, tort plaintiffs could only recoup those costs at the end of an often lengthy legal proceeding which, of course, presents a risk of loss. Consequently, they still might be deterred from fronting the costs necessary to pursue all shareholders as defendants. Further, judicial transaction costs would still be significant. In short, controlling shareholders would still not fully internalize costs. See supra text accompanying notes $329-337$.

340. To the extent that the vast majority of the minority shares in large corporations were concentrated in relatively few hands-for example, in fewer than forty institutionsthere would be fewer transaction costs. But see supra note 46 (noting that 500 shareholders are needed for NYSE listing). 
likelihood of a lawsuit. However, to the extent small shareholders believe that they face a significant risk of suit, they would monitor the corporation to minimize a potential liability risk, or else would simply choose not to invest. ${ }^{341}$ The smallest individual shareholders might lack ready access to information necessary to assess expected liability and, sometimes, the knowledge or skill necessary to evaluate the information. Effective monitoring thus would require significant transaction costs. Because there would be no limit on a small shareholder's potential liability under a pro rata rule, diversification could represent only a partial answer. ${ }^{342}$

However, a control-based liability regime would focus liability only on controlling shareholders. ${ }^{343}$ Consequently, truly small shareholders

341. E.g., Halpern et al., supra note 2, at 125 (explaining that "risk-minimizing response [to unlimited liability] might entail more detailed involvement by owners in managerial supervision, thus generating increased, and wasteful, transactions costs"). Insurance might provide a partial solution to this problem, but probably only a partial one. See Cooper Alexander, supra note 11, at 428 (noting that insurers are not likely to provide shareholders with unlimited liability insurance, which would involve insuring against both the risk of commercial failure and the risk of tort liability). But cf. text accompanying notes 91-93 (arguing that controlling shareholders can encourage company to buy more insurance).

342. Hansmann and Kraakman imply that diversification is still useful under an unlimited liability regime based on an assumption that "even a catastrophic liability judgment [is unlikely to] impose costs exceeding a publicly-traded firm's value by more than, say, a multiple of five." Consequently, a shareholder would rarely be forced into insolvency. Hansmann \& Kraakman, Unlimited Liability, supra note 2, at 1900 . The basis for the assumption is unclear. E.g., Leebron, supra note 2, at 1598 ("[U]nder a pro rata rule, the effect on portfolio strategy depends on the relationship between the magnitude of the largest conceivable loss and its probability."). It is worth noting that in the ten years since Hansmann and Kraakman wrote their article, tort liability awards have continued to increase. For example, the median jury award in defective products cases more than tripled from $\$ 500,300$ in 1993 to over $\$ 1.8$ million in 1999. See Greg Winter, Jury Awards Soar as Lawsuits Decline on Defective Goods, N.Y. Times, Jan. 30, 2001, at A1 (noting, in addition, that total number of product liability cases declined from 1997 to 2000).

343. As under a pro rata standard, however, mutual funds and other investment intermediaries might face responsibility under a control-based liability scheme. See Hansmann \& Kraakman, Unlimited Liability, supra note 2, at 1904 (noting that collection mechanism imposing greater liability on large shareholders might "discourage investment intermediaries such as mutual funds"). However, liability would not be automatic, but would depend on the size of the fund's holdings and other factors. Individual mutual fund shareholder liability seems highly unlikely under a control-based regime.

That funds might have liability, but not individual mutual fund shareholders, might seem anomalous. Such institutional investors, however, may exercise control opportunities in the companies in which they invest as part of ensuring higher returns for their investment. See, e.g., Fox, supra note 188, at 2105 (" $[\mathrm{T}]$ he influence of institutional investors ... appear[s] to be increasing."). Further, institutional investors likely would be in a good position to monitor the companies in which they invest to assure that the companies are adequately insured. Institutional investors themselves could obtain adequate insurance and could keep their investments in a particular company below $10 \%$. In addition, they could presumably include in their contract with individual investors some additional charge for their willingness to bear the risk associated with investment. Although the demand for mutual funds could be reduced, individual investors likely would continue to pay, just as they do now, a premium above what they would pay to invest in 
could avoid their relatively high monitoring costs. The liability of these shareholders would continue to be limited under a control-based regime, and they could continue to minimize investment risks by diversifying, rather than by monitoring. The bulk of corporate monitoring responsibility would be borne by shareholders with the capacity to control, who most likely face comparatively low monitoring costs. ${ }^{344}$

To the extent there is more than one shareholder with the capacity to control the corporation, the controlling shareholders would wish additionally to monitor each others' wealth to assess potential liability exposure for a corporate tort. However, they probably already conduct some monitoring to assess relative control. Further, the number of controlling shareholders for any corporation is likely to be small, so the additional monitoring burden should not be excessive.

4. Costs from Litigation over the Meaning of "Capacity to Control." - A control-based regime could be criticized as generating litigation because it would not impose a detailed ex ante "bright-line" rule and instead would impose a standard in which detail would be developed through judicial application. ${ }^{345}$ In some instances, such as where a shareholder owns $35 \%$ of shares, or arguably is a member of a shareholder bloc that can control the corporation, application of a control-based standard could require a trial judge to evaluate factual evidence and hear expert testimony, resulting in additional transaction costs for litigants and courts and creating some uncertainty about precisely when the rule would apply. ${ }^{346}$

However, even for the case requiring the development of a factual record, courts are not wholly without experience in addressing the capacity to control issue. In the context of ERISA, securities law, and certain environmental statutes, courts have had to evaluate whether a particular

individual stocks for the convenience and superior informational access provided by mutual funds. Finally, to the extent investment intermediaries were discouraged by a control-based regime, the effect would likely be seen primarily in risky industries.

344. See supra text accompanying notes $64-68$. Finally, like the limited liability regime, a control-based regime would continue to make wealth accumulation opportunities available more democratically. Less wealthy shareholders, who tend to hold small percentages of a corporation's stock, would face greater costs under a pro rata regime than a control-based one. Avoiding the "tax" of litigation and a pro rata judgment would require these shareholders to spend substantial sums on information to monitor their corporate investments. Under a control-based regime, less wealthy individuals could invest-as they do now-without risking their entire portfolio. See Presser, Thwarting, supra note 16, at 161-62. Of course, these opportunities also would be available to wealthy individuals who elected to buy only small shares of ownership of a corporation.

345. See generally Louis Kaplow, Rules Versus Standards: An Economic Analysis, 42 Duke L.J. 557, 597-99 (1992) (comparing economic effect of detailed rules with nonspecific standards in a variety of settings).

346. E.g., Hansmann \& Kraakman, Unlimited Liability, supra note 2, at 1932 ("In short, it is very difficult to determine where to drive the piton into this particular slippery slope."); cf. Note, supra note 59, at 996-97 (describing litigation reduction as an advantage of limited liability). 
shareholder has actual or potential control over a corporate entity. ${ }^{347}$ There might be more litigation over the issue of liability for a particular shareholder under a control-based regime, compared with a pro rata rule. However, the question is certainly no more difficult to answer than liability under the current veil piercing standard, which requires a court to evaluate whether the parent is the subsidiary's "alter ego" or has fraudulently used the corporate form. ${ }^{348}$

Perhaps more critically, the lack of a detailed ex ante rule might require a potential corporate shareholder to expend resources determining whether it would face potential "capacity to control" liability in the event of a tort or statutory judgment exceeding corporate assets. Further, the lack of a bright-line rule might deter individuals who wish to invest in mutual funds or pension funds. These fears might result in reduced investment, especially if these institutions held large stock positions in a particular company. ${ }^{349}$

The group of shareholders that would need to spend resources on determining possible exposure would be limited. For example, it is clear that a majority shareholder and a shareholder with a smaller stake in a public corporation would be vicariously responsible and not responsible, respectively. However, shareholders possessing or considering tbe acquisition of large nonmajority shares of equity would face the costs of determining whether they have the "capacity to control." Similarly, a potential mutual fund investor might demand assurance from the mutual fund that it will keep investments in particular companies to below $10 \%$ of equity or perhaps assume any risk of excess liability.

Nonetheless, the costs associated with a less detailed standard still seem outweighed by the problems that would be created by trying to devise a detailed bright-line rule. Permitting the detail of a control-based regime to be developed in the context of particular cases still seems the best approach for several reasons. First, assuming that courts do not regularly make legal errors, the cost for a private shareholder to determine whether it possesses the "capacity to control" the corporation is likely to be relatively low. The shareholder that must make this determination typically will hold a significant block of stock. Such a shareholder is likely to have control over or inexpensive access to the information necessary to determine whether it has the "capacity to control" within the meaning of the rule: for example, the proportion of shares held by others, the shareholder's ability to select directors, and whether the shareholder is viewed by the market as possessing "control."

347. See supra text accompanying notes 303-310.

348. Concededly, at least at the outset, tort victims likely would sue shareholders more than they currently do, which could increase transaction costs. On the other hand, the liability of very large and very small shareholders is clear even under a control-based rule.

349. See also supra note 343 (discussing risk of increased liability for mutual funds and possible responses). 
Second, a rule that ex ante is more detailed, with less room for adjustment in individual cases, is likely worse. It could be both significantly underinclusive and overinclusive. For example, a more detailed rule that selects a precise level of stock ownership, such as 35\%, as "control," would impose no responsibility on the $34 \%$ shareholder that is the largest corporate shareholder, is strongly represented on the board of directors, and is the only shareholder to hold more than $0.5 \%$ of stock. However, it might mistakenly include the $36 \%$ shareholder in the corporation that is controlled by a $64 \%$ shareholder. In other words, a proper determination of "capacity to control" should depend, at a minimum, not only on the shareholder's absolute share of ownership, but also on the share of ownership compared with the shares held by others. The potential for dramatic case-by-case variation weighs in favor of not attempting a detailed ex ante definition of the shareholder with the capacity to control. ${ }^{350}$

It is worth noting, however, that a similar sounding rule developed by a federal appeals court in the context of lender liability under the Comprehensive Environmental Response, Compensation, and Liability Act has been subjected to substantial criticism. In United States v. Fleet Factors Corp., the Eleventh Circuit held that a lender with the "capacity to influence" its borrower's operations would have statutory cleanup liability in the event of improper waste disposal. ${ }^{351}$ The criticism of Fleet Factors stemmed, in part, from lenders' concerns about the uncertainty they would face about their potential liability. ${ }^{352}$

Concededly, a control-based liability standard for shareholders would create some uncertainty, just as it did for lenders after Fleet Factors

350. See generally Kaplow, supra note 345 , at 559 (offering an economic analysis of the extent to which legal commands should be promulgated as rules (ex ante) or as standards (ex post)).

351. 901 F.2d 1550, 1557 (11th Cir. 1990), reh'g denied en banc, 911 F.2d 742 (11th Cir. 1990), cert. denied, 498 U.S. 1046 (1991). I am grateful to Ronald Mann for pointing out the potential similarities between a control-based liability regime for shareholders and the Fleet Factors lender liability standard.

352. E.g., G. Van Velsor Wolf, Jr., Lender Liability After Fleet Factors: Perceptions and Realities, in Fourth Annual Advanced ALI-ABA Course of Study: The Impact of Environmental Law on Real Estate and Other Commercial Transactions 183, 197-99 (1991) (noting lenders' reaction to Fleet Factors); Widespread Havoc Predicted by ABA [American Banking Ass'n], Others Supporting Fleet Factors Review, 55 Banking Rep. (BNA) 792, 792 (1990) [hereinafter Widespread Havoc] (indicating ABA's urging of U.S. Supreme Court to review Fleet Factors); Dennis R. Connolly, Superfund Whacks the Banks, Wall St. J., Aug. 28, 1990, at A10 (discussing effect of Fleet Factors decision on banks); Fleet Factors Files in Supreme Court, Says Ruling Disrupts Commercial Lending, 55 Banking Rep. (BNA) 586, 586 (1990) (reporting Fleet Factors Corp. filing review petition to U.S. Supreme Court; arguing Fleet Factors decision "threatens to disrupt 'normal and prudent commercial practices'"). For some of the commentary on Fleet Factors, see George Anhang, Cleaning up the Lender Management Participation Standard Under CERCLA in the Aftermath of Fleet Factors, 15 Harv. Envtl. L. Rev. 235, 236 (1991); Michael B. Kupin, New Alterations of the Lender Liability Landscape: CERCLA After the Fleet Factors Decision, 19 Real Est. L.J. 191, 209-15 (1991). 
until the decision's import was weakened by administrative guidance and ultimately reversed by a statutory amendment. ${ }^{353}$ However, the Fleet Factors liability standard was perceived to be considerably broader than the shareholder liability standard discussed here. Some believed the Fleet Factors standard would impose liability on any lender with a secured interest because of standard monitoring provisions in commercial loan contracts. ${ }^{354}$ Further, a number of other criticisms led to Fleet Factors being considered an infamous decision, including that it would have imposed greater statutory liability on lenders than on parent companies, other shareholders, or managers of a company that had improperly disposed of hazardous waste. ${ }^{355}$ These types of criticisms were particular to the statutory regime at issue and would not apply to a control-based shareholder liability regime.

5. Exclusion of Companies Without Controlling Shareholders. - The company without a single shareholder in a position of control presents a special case. Such a corporation might, for example, fit the Berle-Means profile of a corporation run by managers and owned by numerous individual shareholders, none of whom individually (or as a bloc) possesses the capacity to control the corporation. To the extent large tort liabilities exceed corporate assets, a control-based regime would authorize no additional recovery from the corporation's shareholders. Consequently, the corporation would not fully internalize the costs of its risky behavior. By comparison, the proportional liability rule urged by Hansmann and Kraakman would, in theory, provide for a pro rata recovery from each shareholder.

Whether this situation would arise frequently depends on, among other things, the extent of excessive risk taking attributable to these types of corporations. Even without further empirical investigation, several factors suggest that the theoretical difference in treatment of corporations without controlling shareholders may not create a substantial practical difference between the regimes. First, even of the largest corporations, a considerable number have a controlling shareholder. ${ }^{356}$ Furthermore, close corporation ownership is generally highly concentrated. Given the

353. Asset Conservation, Lender Liability, and Deposit Insurance Protection Act of 1996, Pub. L. No. 104-208, $\$ \S 2501-2502,110$ Stat. 3009-462, 3009-462-69 (1996).

354. E.g., George Freeman, Recent Case Law May Expand Lenders' Risks Under Superfund, Nat'l L.J., Sept. 17, 1990, at 19 ("A 'capacity to influence' test may well make all secured creditors vulnerable on the grounds of some inherent power to affect their borrowers' behavior."); Connolly, supra note 352, at 10 ("Lenders may be reluctant to finance clients with any involvement in environmental clean-up . . . for fear that such financial arrangements, in and of themselves, might establish a sufficient level of control to trigger liability."); Widespread Havoc, supra note 352, at 792 (noting American Bankers Association argument that the decision "has denied lenders the benefit of the secured credit exemption under the Superfund law").

355. See Kupin, supra note 352, at 209-15 (critiquing Fleet Factors; advising lenders on ways to avoid CERCLA liability).

356. See supra notes $47-48$ and accompanying text. 
state of current information, the best conclusion is that a corporation lacking a shareholder with capacity to control is unlikely to occur in the universe of close corporations and probably does not represent the bulk of public corporations. A control-based liability regime could create an incentive for shareholders to avoid control completely, so that corporations would no longer have controlling shareholders. However, such an outcome seems unlikely in view of the substantial benefits of possessing control. ${ }^{357}$

If that were to happen, however, managerial risk aversion would continue to deter these corporations from selecting excessively risky actions. ln the absence of a shareholder with the capacity to control, managerial risk aversion will be relatively unhindered. Managers can better serve their own goals-like keeping their jobs-in preference to strictly maximizing shareholder profits. As discussed above, even in the absence of a new liability regime, managerial risk aversion in corporations without controlling shareholders is likely to temper limited liability's moral hazard..$^{358}$

Moreover, a pro rata rule is unlikely to offer significant practical advantages in the treatment of a corporation without a controlling shareholder, even if such a corporation were to engage in excessively risky activity. Under a pro rata rule, a plaintiff would face substantial difficulty in obtaining compensation due to transaction costs. In the case of a public corporation without a controlling shareholder, for example, a tort or statutory claimant would be compelled to pursue hundreds or thousands of small shareholders, each for only a small fraction of the tort victim's total loss. Considerable transaction costs could consume much of the potential recovery. For example, a claimant with $\$ 5,000,000$ in injuries, faced with suing 5000 individual shareholders each for $\$ 1000$, could conceivably be deterred by litigation costs from embarking on the process at all. ${ }^{359}$

357. See supra text accompanying notes 206-231.

358. The presence of stock options is unlikely to reduce managerial risk aversion significantly. See supra note 200 and accompanying text.

359. Joseph Grundfest also has argued that the capital markets will circumvent a pro rata liability system by "strategically generating a large clientele of investors who are de facto attachment-proof in actions seeking recovery of proportionate damages." See Grundfest, supra note 7, at 389. Grundfest's argument that, as a practical matter, very small shareholders are "naturally immune" to a proportionate liability system, see id. at 397 , of course does not apply to a control-based liability system. As argued above, shareholders are unlikely to avoid control altogether because of the significant benefits control confers. See supra text accompanying notes 206-231. Further, Grundfest's arguments that people will invest in a company in other forms, such as through debt, will simply concentrate equity in a smaller group of individuals or institutions. That is unlikely to seriously undermine the application of a control-based liability rule, unless that smaller group is judgment-proof, which also seems relatively unlikely. See Henry Hansmann \& Reinier Kraakman, Do the Capital Markets Compel Limited Liability? A Response to Professor Grundfest, 102 Yale L.J. 427, 430 (1992) [hereinafter Hansmann \& Kraakman, Do Markets Compel Limited Liability?] ("The supply of high rollers with just the right 
6. Changes in Equity Ownership Distribution. - The capacity to control rule might be conceptualized as a tax on control. Even if shareholders do not avoid control altogether, the rule will likely result in some change in the distribution of equity ownership. ${ }^{360}$ Because the acquisition of control would be accompanied by new potential liabilities, the price of acquiring a controlling share in a risky business is likely to decline. Under a control-based liability regime, the tax is "flat." If a shareholder were to acquire the "capacity to control" by virtue of share ownership, the shareholder's decision to acquire further shares in the company would not be accompanied by any further increase in liability exposure. So, for a shareholder that would have held control in a corporation under a limited liability regime, one might expect the same shareholder either to hold a greater percentage of shares under a control-based regime or else to avoid the acquisition of a controlling share altogether.

This could be termed an inefficient "distortion." For example, to the extent shareholders completely stop acquiring controlling shares of corporations, agency costs would increase and managers would be monitored less. Such an outcome, however, appears unlikely in view of the obvious benefits of control. ${ }^{361}$

Assuming a shareholder elects to retain control, but the presence of the rule results in the shareholder holding a greater percentage of shares, the efficiency effect of the "distortion" is unclear. The shareholder may have greater expropriation opportunities, but agency costs may decline. Meanwhile, numerous other distortions are present in the corporation as a profit maximizing enterprise. Consequently, the fact of a new "distortion" in ownership distribution alone cannot be assumed to reduce social welfare. ${ }^{362}$ For example, one study has suggested that diluted ownership firms and extremely concentrated ownership firms both tend to outperform firms where the largest shareholder is medium-

combination of capital, risk preference, and management expertise to pursue this strategy is likely to be very limited."). Grundfest also argues, however, that to the extent shareholders are foreign, asserting jurisdiction over and collecting judgments from them will be very difficult. Grundfest, supra note 7 , at $397-98$. While this problem is not a trivial one, it could be addressed through targeted regulations, such as domestic ownership rules or insurance requirements. See Hansmann \& Kraakman, Do Markets Compel Limited Liability?, supra, at 433.

360 . In the absence of a capacity to control rule, the marginal benefit to a controlling shareholder of, say, the share that gives it majority control (51\% of the voting shares) is likely to be quite high. By comparison, the marginal benefit of the share that gives the controlling shareholder $98 \%$ control, rather than $97 \%$ control, is likely to be considerably less: the entitlement to receive additional dividends from an enterprise that the shareholder already controls. Of course, the value of the share still would be higher than the marginal benefit of a share to a shareholder that had no capacity to control the corporation.

361. See supra text accompanying notes 206-231.

362. See supra note 192 (regarding theory of the second-best). 
sized. ${ }^{363}$ Moreover, agency costs associated with monitoring managers and other shareholders may vary depending on the size and sophistication of the shareholder. At bottom, the implications of such a change are unclear.

7. Overdeterrence of Some Socially Beneficial Activities. - Another criticism of a control-based regime is that it could overdeter certain risky, but socially beneficial activities, if they present a risk of tort or tort-like statutory liability in excess of corporate assets. Because a shareholder with capacity to control would bear all the excess costs if the corporation faced a tort judgment, the shareholder might find that the shareholder's expected costs from a new risky project (the losses resulting from increased corporate costs of paying liability judgments, together with the stockholder's share of the costs that exceed corporate assets) outweighed the expected benefit to the shareholder, even if, overall, expected benefits exceeded expected costs. ${ }^{364}$ A $60 \%$ parent corporation, for example, with the capacity to control (and hence exposure to $100 \%$ of tort liability), but with the right to receive significantly less than $100 \%$ of the marginal value of a new corporate activity, might oppose a corporate activity whose social benefit exceeds the social costs if the activity presented the risk of tort or statutory liability in excess of corporate assets. The shareholder might attempt to deter corporate management from undertaking the project.

If a corporation were to be properly capitalized or insured, however, there would be no overdeterrence effect. Only if insurance (or capitalization) were inadequate would a controlling shareholder face a risk of liability disproportionate to the shareholder's expected gain from the activity. As discussed above, the incentive for a controlling shareholder under a control-based liability regime thus would be to encourage the corpora-

363. See Nagar et al., supra note 44, at 3-4, 22-23 (discussing close corporations). The effect of ownership concentration in large corporations, however, is less clear. Cf. Lucian Arye Bebchuk \& Luigi Zingales, Ownership Structures and the Decision to Go Public, in Concentrated Corporate Ownership 55, 58-59 (Randall K. Morck ed., 2000) (noting that going public and diluting control may reduce company's value because of "agency costs thereby created"); see also Demsetz \& Villalonga, supra note 47, at 1 (finding "no systematic relation between variations in ownership structure and variations in firm performance"). In any event, while a control-based regime might encourage a shareholder seeking control to hold more shares, rather than fewer, it is far from clear that the shareholder would try to acquire the nearly complete control that would best facilitate expropriation opportunities.

364. Halpern, Trebilcock, and Turnbull describe a related situation:

If [under unlimited liability] the wealthy shareholder buys more shares, then the probability distribution of his end of period wealth becomes more symmetric, since he has more claims to the firm's earnings in the event of profitable operations to match his large potential loss in the event of default and the insurance provided to other shareholders is reduced. This will result in the stock price of the wealthy investor's holdings being less negative or even positive.

Therefore, a capital market will exist, and wealthy shareholders will purchase equity claims of corporations.

Halpern et al., supra note 2, at 130-3I. 
tion to acquire insurance or to capitalize more appropriately. When insurance and capitalization are adequate, a controlling shareholder is likely to view a business opportunity as privately advantageous when it is socially advantageous. By comparison, under the pro rata regime, a controlling shareholder's incentive to make sure a corporation is fully insured or well-capitalized will be inadequate. ${ }^{365}$

Any overdeterrence effect from a control-based regime would therefore most likely occur in connection with a risky corporate activity that is uninsurable. Should a controlling shareholder be presented with socially beneficial activities presenting uninsurable risks, however, such a shareholder might elect to avoid them.

The significance of an overdeterrence effect would depend not only on the presence of uninsurable risks, but also on several other factors. The larger the shareholder's proportion of ownership and the value attached to control of the corporation, the smaller the overdeterrence effect. A parent corporation or controlling shareholder with all or nearly all of a corporation's shares, for example, would not likely be overdeterred because the shareholder could expect to receive nearly all the bene-

365. See supra text accompanying notes 329-337. Some also might argue that unfairness is inherent in the control-based regime's placement of $100 \%$ responsibility for tort liabilities in excess of corporate assets on, say, an $80 \%$ shareholder because such a shareholder does not have the right to collect $100 \%$ of the company's dividends. Nevertheless, the primary effect of a control-based regime likely will be that a controlling shareholder will want its corporation to be properly insured. If the corporation is properly insured, then the controlling shareholder's share of costs will not be disproportionately larger than its ability to benefit. In the case of losses exceeding a corporation's assets, the control-based regime admittedly would not treat every shareholder alike. The goal of treating every shareholder alike, however, is something of a red herring, since they are alike in their ability to benefit financially from the corporation only in that they all have the identical per share entitlement to receive dividends. See supra text accompanying notes 206-231 (discussing unique advantages of control).

In that sense, the control-based regime would be no different from veil piercing rules as presently applied, or from the "controlling persons" liability imposed by the securities law. Under current law, only those shareholders whose circumstances or conduct satisfy the veil piercing standard are responsible for the corporation's liability. For example, in State ex rel. Celebrezze v. Specialized Finishers, Inc., after finding that veil piercing was clearly appropriate, the court apportioned environmental liability unequally among a corporation's four shareholders (each of which held one-fourth the shares), with the shares ranging from $10 \%$ to $48 \%$. 604 N.E.2d 842, 851 (Ohio Com. Pl. 1991). See supra note 25 (discussing Wisconsin and New York statutes holding only largest shareholders responsible for unpaid wage claims); cf. United States v. Pollution Abatement Servs., 763 F.2d 133, 135 (2d Cir. 1985) (holding two of four shareholders directly liable under Rivers and Harbors Appropriations Act); Vermont v. Staco Inc, 684 F. Supp. 822, 835 (D. Vt. 1988) (holding some, but not all, individual stockholders directly liable under RCRA based on "authority to control" corporation's mercury releases).

Finally, a control buyer's preference regarding liability exposure will be reflected in the price that a control buyer is willing to pay for a controlling share. If such a buyer values a controlling share less as a result of the potential responsibility that accompanies it, the buyer will simply pay less for it. There could, of course, be some unfairness for current controlling shareholders in risky industries when a capacity to control rule is first implemented. 
fits, as well as the costs, distributed by the firm as a result of a particular activity. The evidence on the value of control discussed above suggests that it is quite valuable-control premiums very often range upward of $30 \%$ to $40 \%$ of share prices. ${ }^{366}$ However, a shareholder with, say, a $60 \%$ share of corporate ownership, but with control assumed to be worth only an additional $10 \%$, might choose to forego a socially beneficial project that presents significant uninsurable liability risks in excess of corporate assets.

Control is likely to be fairly valuable, and shareholders often will have more control than assumed in this example. Moreover, depending on the activity, controlling shareholders very often can choose the middle ground of influencing the corporation to invest in safeguards that will minimize the activity's potential risk.

Ultimately, however, the precise scope of any overdeterrence of uninsurable activities-and how that would compare with the underdeterrence effect under a pro rata regime-depends on empirical questions, including the distribution of ownership in corporations, the value of control, and the availability of insurance for risky corporate activities. ${ }^{367}$

8. General Objections to Expanded Shareholder Liability. - Another set of objections flows from the attempt to replace limited liability with any rule that imposes greater shareholder liability, whether it is a pro rata rule or a control-based regime. Many of these objections have been effectively answered by Hansmann and Kraakman in their defense of the pro rata rule. Consequently, discussion of these objections is not a central focus of this Article. The following discussion is intentionally brief and contains only a few additional comments beyond those of Hansmann and Kraakman.

a. Public stock markets. - Some commentators have argued that any change from limited liability would impair the tradability of shares on a public stock exchange. Such arguments are ill-founded. The argument had been that under a shareholder liability rule, the price of a particular share would depend not only on the wealth of the individual shareholder, but also on the wealth of every other shareholder. Shares would no

366. See supra note 207.

367. A related argument is that an expanded shareholder liability regime would impose too much tort liability. This criticism rests on a belief that the tort system is deeply flawed and should be reformed and that expanding shareholder liability would tend to increase the impact of those flaws by bringing more potential defendants into the tort system.

However, retaining shareholder limited liability as a partial solution to tort reform issues seems both underinclusive and overinclusive. To the extent the tort system is flawed, the class of affected defendants stretches far beyond corporate shareholders. Moreover, to the extent a tort suit legitimately seeks compensation and to set correct incentives for conduct, inappropriately shielding shareholders would fail to address the uncompensated externality that is the focus of this Article.

Even conceding that tort liability rules require reform, that problem should be treated transparently. Rather than trying to reduce the problems of a flawed tort system by retaining limited shareholder liability, the focus should be directly on reform of the tort law. 
longer be homogeneous. ${ }^{368}$ Hansmann and Kraakman, however, have persuasively argued that the public tradability of shares would be unaffected under a pro rata unlimited liability regime because a share would have the same expected value for each shareholder. ${ }^{369}$

A control-based regime would, of course, affect the prices at which controlling shares were traded, since an ownership share conferring capacity to control on its owners would confer not only the higher expected benefits of control, but also a greater component of responsibility for corporate risk taking. Since they would be jointly liable in the event of a liability exceeding corporate assets, owners of control blocks likely would wish to monitor each others' wealth. However, controlling shares in publicly-traded corporations generally are not traded at published market prices, but are bought and sold at a negotiated premium above that price ${ }^{370}$ Further, as noted above, shareholders with control probably already monitor each other to assess relative control. Finally, the group of controlling shareholders is likely to be small. ${ }^{371}$

As discussed above, the market might perceive uncertainty in some circumstances about whether a court would deem a particular shareholder to have the capacity to control a corporation, and hence to be liable under a control-based regime. ${ }^{372}$ If this were true, that could impair the tradability of marginal shares that could give such a shareholder the capacity to control. Other than these shares, the tradability of other shares on public stock exchanges would be unaffected.

b. Disinvestment in socially beneficial industries. - A second possible criticism is that a shareholder liability rule might generally reduce the incentive to invest in certain industries that are risky but widely agreed to be socially beneficial, such as pharmaceutical research. ${ }^{373}$

368. See Easterbrook \& Fischel, Economic Structure, supra note 6, at 42-43.

369. Hansmann \& Kraakman, Unlimited Liability, supra note 2, at 1903-04.

370 . The only exception here would be the attempt to quietly assemble a block of shares in a publicly-traded company. However, this is a relatively rare form of acquisition, and once an acquirer has obtained $5 \%$ of a company's stock, a report must be filed with the SEC. See Securities Exchange Act of 1934, $\$ 13(d), 15$ U.S.C. $\$ 78 \mathrm{~m}$ (d) (1999).

371. E.g., Hansmann \& Kraakman, Unlimited Liability, supra note 2, at 1891-92 (arguing that it is feasible to negotiate among close corporation shareholders under unlimited liability rule). Further, historical evidence suggests that even in the absence of homogeneous shares, individuals will invest in transferable shares in business enterprises. See Blumberg, Limited Liability, supra note 2, at 581-82 (discussing extensive individual investment in English joint stock associations).

372. See supra text accompanying notes $345-350$.

373. Relatively little systematic empirical research appears to have been conducted comparing investment levels in limited liability regimes with those in unlimited liability regimes, either joint and several or pro rata liability. One recent study, however, argues that California's move from pro rata liability to limited liability in 1931 had no detectable effect on share prices. Mark I. Weinstein, Share Price Changes and the Arrival of Limited Liability in California (Univ. of S. Cal. Marshall Sch. of Bus., Dep't of Fin. \& Bus. Econ., Working Paper No. 01-14, 2001), available at http://papers.ssrn.com/paper.taf?abstract_ id=286799 (last visited Feb. 6, 2002) (on file with the Columbia Law Review). 
Under a control-based regime, however, the incentive would be for a controlling shareholder to ensure that a corporation is adequately capitalized or insured in view of the risks of its activities. To the extent there is a social need for "uninsurable" risky activities, limited liability rules would seem to go considerably further than necessary to address it. These rules encourage all risky activities, without distinguishing uninsurable activities or those that society might wish to subsidize from those that it does not. A preferable approach would be to subsidize particular socially beneficial activities selectively. ${ }^{374}$ For example, to the extent pharmaceutical research is difficult to insure-hence leading controlling shareholders to avoid socially beneficial research opportunities-we might choose to offer tax credits for money spent on pharmaceutical research or to subsidize the research outright.

c. More "fly-by-night" corporations in risky industries. - A third potential criticism is that excessively risky activities would be undertaken more by "fly-by-night" corporations, which are poorly capitalized, owned by individuals with few assets, and financed with debt. ${ }^{375}$ Hansmann and Kraakman term this the "high roller" problem. Under either a pro rata or a control-based regime, these corporations would not fully bear the costs of their activities because their shareholders would be judgmentproof once they are relieved of their few assets. These entities would effectively continue to have limited liability even in the presence of a shareholder liability rule. As a consequence, the investors in the riskiest activities would be those with the smallest incentive to minimize the risks. This could not only undermine the effectiveness of a shareholder liability rule at eliminating limited liability's moral hazard, but also somehow make matters worse by putting "fly-by-nights" in charge of the riskiest activities. "Fly-by-night" corporations might take fewer precautions or insure less;

374. See Leebron, supra note 2, at 1577 (arguing that unlimited liability serves a "valuable regulatory function" because enterprises "would have to identify themselves and request government assistance").

375. E.g., Richard B. Stewart \& Bradley M. Campbell, Lessons from Parent Liability under CERCLA, Nat. Resources \& Env't, Winter 1992, at 7, 8 (contending that eliminating limited liability would result in "incentives for ownership by undercapitalized or marginal firms with fewer assets at risk"); Hansmann \& Kraakman, Unlimited Liability, supra note 2, at 1911-13 (discussing "high roller" problem).

A related problem-also common to the pro rata regime-would be that the decline in the price of a controlling share might lead corporations to seek more debt, rather than equity, financing. In addition to creating the "fly-by-night" problem discussed in the text, this might lead overall to less monitoring of management and greater inefficiency. But see Leebron, supra note 2, at 1640 (arguing that shift from equity to debt more likely to be seen under limited liability regime than under unlimited liability regime; "[u]nlike unlimited liability, limited liability is not neutral with respect to its effect on the capital structure of firms"). In any event, it is unclear why lenders would be less sophisticated monitors of corporate managers than equity investors. See George G. Triantis, Debt Financing and Motivation, 31 U. Rich. L. Rev. 1323, 1326 (1997) ("Debt contracts have a relatively under-appreciated role in deterring, detecting and correcting managerial slackthat is, lapses in managerial competence or effort, as well as excessive managerial compensation or perquisite consumption." (footnote omitted)). 
risky activity could be undertaken more by these corporations not because they are expert at managing such activities, but because the "fly-bynights" would be more judgment-proof and hence more risk preferring. Further, they would be likely to seek higher levels of debt financing, which in turn would impose "efficiency losses in the form of the agency costs of risky debt." 376

The prospect of judgment-proof shareholders is, of course, equally likely under limited liability, since generally all shareholders, not just owners of "fly-by-nights," are "judgment-proof" under limited liability. ${ }^{377}$ The other consequences could potentially occur under either a pro rata regime or a control-based regime. Hansmann and Kraakman have reasoned that the other consequences are unlikely because for most unusually hazardous activities, a significant investment in a specialized plant and equipment is required. Consequently, a significant problem associated with "fly-by-night" corporations would only arise if there were a large number of very wealthy individual shareholders who also did not especially mind the prospect of personal bankruptcy. ${ }^{378}$ In view of the stigma and general discomfort associated with individual bankruptcy, this seems unlikely. ${ }^{379}$ Declaring personal bankruptcy is generally not appealing, regardless of an individual shareholder's wealth. ${ }^{380}$

Finally, even assuming a "fly-by-night" problem, a control-based regime would still be preferable to a limited liability regime. ${ }^{381}$ The "fly-bynight" strategy is already available under current law. Under controlbased liability, a "fly-by-night" might have a comparative advantage in bearing the risks of excessively risky corporate activity and thus might be more likely to enter a relatively risky industry. A control-based regime would certainly be less effective in compelling a corporation to internalize liability if its shareholders were largely judgment-proof.

376. Hansmann \& Kraakman, Unlimited Liability, supra note 2, at 1912.

377. Id.

378. Id. at 1912-13.

379. See, e.g., Schwartz, supra note 77, at 707 ("Persons dislike bankruptcy and strive to avoid it.").

380. One recent empirical paper confirms that the prospect of personal bankruptcy does indeed affect individual decisionmaking. The larger the size of a state's bankruptcy exemptions, say, for personal residences, the more likely individuals were to use a noncorporate form for businesses they started. Wei Fan \& Michelle J. White, Personal Bankruptcy and the Level of Entrepreneurial Activity 20-22 (July 2000), available at http:/ /www.law.umich.edu/centersandprograms/olin/00-013.htm (unpublished manuscript, on file with the Columbia Law Review).

381. The concern would remain that, to the extent they are drawn to risky industries, "high rollers" might not be the individuals most skilled in managing highly risky enterprises, resulting in efficiency losses. Hansmann \& Kraakman, Unlimited Liability, supra note 2, at 1912. As noted, however, the distasteful prospect of personal bankruptcy that the ultimate owners of risky enterprises would face is likely to deter many individuals from selecting excessively risky activities simply because they might possess the "comparative advantage" in bearing judgments. Further, the concern seems outweighed by the overall improvement in the incentives for businesses to take care when entering into these industries. 
However, even if some "fly-by-night" corporations moved into risky industries under a control-based regime or other regime of expanded liability, the remainder of corporations, with wealthier shareholders, would be less able to externalize the costs of excessively risky activities. Moreover, even if "fly-by-night" corporations could externalize some of their costs under a capacity to control rule, they would still internalize more costs than under the current regime. ${ }^{382}$ Under a control-based regime, all shareholders with a capacity to control, even less wealthy ones, would have their assets at stake. Shareholders of such corporations would have to be sufficiently risk preferring to "incur a substantial chance of personal bankruptcy if tort damages should prove large."383 Again, the stigma and discomfort that generally accompanies personal bankruptcy is likely to prove a deterrent.

In short, even though such corporations might be relatively more risk preferring than well-capitalized corporations under a capacity to control rule, they would still likely be less risk preferring overall than under current law. Consequently, while an empirical question remains, the undertaking of excessively risky activity by "fly-by-night" corporations would still likely be lower, at an absolute level, under a control-based regime than under a limited liability regime.

d. Disaggregation. - This is a different version of the "fly-by-night" problem. Large companies might seek to disaggregate their risky businesses and spin them off piecemeal to small, less well-capitalized firms, but then continue to do business with those firms. ${ }^{384}$ The large company would, through contract, continue to engage in the risky activity, but would shift the liability risk to a more risk-tolerating entity. Hansmann and Kraakman give the example of a large oil company, which, rather than continuing to ship its oil in tankers that it or a subsidiary owns, might sell the tankers to small companies and then contract with them to transport the oil. ${ }^{385}$ Another example might be a metal smelting operator that purchases a mine in order to guarantee a supply of ore to the smelter. Under an expanded shareholder liability regime, the smelter operator would instead approach a mine operator and contract to supply ore. The disaggregation/contracting phenomenon is likely to be seen primarily in vertically integrated businesses, which typically invest in risky businesses as a way of ensuring supply or distribution for other parts of the business. ${ }^{386}$

382. As discussed earlier, a pro rata liability rule would generally be less effective than a control-based liability regime in ensuring that firms internalize their costs. See supra text accompanying notes 329-337.

383. Hansmann \& Kraakman, Unlimited Liability, supra note 2, at 1912.

384. 1d. at 1913-15.

385. 1d. at 1913-14.

386. E.g., Arrow, supra note 61 , at $140-41$ (noting that companies vertically integrate to minimize market risks that might lead to variations in supply). 
1mposing a shareholder liability rule might reduce a parent company's incentive to integrate vertically. However, the incentive for a company to purchase those goods or services, rather than to integrate them into the firm, would be offset by the loss of the very features that make vertical integration attractive in the first place. Such features include economies of scale and quality of management, greater assurance that a product will be effectively marketed, and the smaller risk of a shortage of a critical material. ${ }^{387}$ Anecdotal evidence suggests that disaggregation/ contracting is not likely to be a dominant strategy. After the Exxon Valdez oil spill, in which Exxon elected to bear responsibility for the oil spill of its subsidiary's tanker, some oil companies did divest themselves of their tankers. ${ }^{388}$ However, other oil companies believed the best practice was to own the tankers to ensure that they were managed appropriately for safety. ${ }^{389}$

\section{ConCLUSION}

To date, writing on limited liability has not delved significantly into the different incentives that may be faced by particular shareholders. Among other things, controlling shareholders are in a position to monitor and control managers and to reap additional benefits, beyond their pro rata share of ownership, from corporate activity. Consequently, limited liability's moral hazard is likely to be most severe when a corporation's shareholders include one (or more) with the capacity to control. At the same time, the efficiency justifications for limited liability, which largely depend on a prediction that shareholders will face significant monitoring costs, are strongest in the case of the individual shareholder that holds a small percentage of stock and are quite weak in the case of

387. Id.; Hansmann \& Kraakman, Unlimited Liability, supra note 2, at 1914; Leebron, supra note 2, at 1616 ("If there are in fact no efficiencies from integration, then we have lost nothing by forcing the disintegration as a result of the veil-piercing threat."). Knowledge-based considerations-the costs of acquiring the information needed for vertical integration versus the cost of purchasing the service elsewhere and having those individuals acquire the information-might also create an incentive to integrate vertically. E.g., Harold Demsetz, The Theory of the Firm Revisited, in The Nature of the Firm 159, 172-73 (Oliver E. Williamson \& Sidney G. Winter eds., 1991) (noting that because information costs for new business are not significantly greater, steel manufacturing firm may find it worthwhile to set steel "into its structural places" rather than to sell steel unriveted to construction companies). For an example of the risk of relying on other companies to provide marketing services, see Candy Sagon, Frozen Out: How a Pint-Sized Company Learned a Giant Lesson, Wash. Post, May 3, 1995, at E1 (describing how small company, Sharon's Sorbet, lost its market because its distributor, Haagen-Dazs, decided to end distribution contract and market its own sorbet). See generally Demsetz, supra, at 162-64 (discussing calculus for firm's choice of "in-house production" rather than external procurement).

388. Alan Abrams, Oil Companies Shed Tankers to Reduce Liability Risks, J. Com., Feb. 28, 1995, at 1A.

389. See id. ("'If you want to control liabilities in large oil companies, you ought to bring it in-house." (quoting ARCO executive)). 
the controlling shareholder. Empirical evidence suggests that for a substantial number of corporate shareholders, limited liability's promise of transaction cost reductions enhances efficiency little, if at all, despite the potentially significant efficiency costs it imposes in the form of corporate opportunities to externalize costs.

Although it represents one solution to limited liability's moral hazard, the pro rata liability regime alternative does not fully address shareholder differences, especially the special position of controlling shareholders. As a consequence both of this and of the significant transaction costs facing a plaintiff trying to obtain compensation from shareholders, the pro rata liability regime might not ensure that corporations fully internalize the costs of risky activities.

A control-based liability regime would focus more particularly on the special position of controlling shareholders. By holding them fully responsible for tort liabilities that exceed a corporation's assets or insurance, the regime likely would get corporations with controlling shareholders to internalize their costs. Furthermore, controlling shareholders would be far more likely to insist that a corporation purchase insurance at an adequate level. To the extent a corporation has not done so (or an activity is uninsurable), tort plaintiffs still would face many fewer transaction costs than under a pro rata regime. While it has its own shortcomings, a control-based liability regime is a strong candidate as a solution to limited liability's moral hazard.

A definitive comparative analysis of these regimes requires evaluating the varying empirical assumptions each makes regarding the location and significance of different types of transaction costs. Limited liability defenders presume that under a regime of expanded shareholder liability, shareholders would incur substantial information-gathering and monitoring costs, and that, on balance, limited liability is justified by the need to minimize these costs. This assumption seems highly questionable in the case of controlling and institutional shareholders, but it deserves fuller empirical investigation as to other shareholders. Similarly, the position that shareholders are better risk bearers than tort victims seems open to doubt, especially for corporate and institutional shareholders and those shareholders with the capacity to control. The risk aversion issue too deserves further empirical investigation, especially in connection with individual shareholders.

Proponents of pro rata shareholder liability also make implicit empirical assumptions regarding transaction costs. They assume that under such a regime, small shareholders would not need to expend resources on monitoring because diversification would remain a viable strategy for minimizing risk, and that tort plaintiffs seeking compensation from multiple corporate shareholders under an expanded liability regime would be able to obtain compensation (and corporations would internalize their costs) because litigation costs would not prove a significant impediment. Both these assumptions also are open to question, and empirical investi- 
gation would be worthwhile here as well. Moreover, the extent to which a controlling shareholder can obtain benefits from corporate activity, in excess of its pro rata ownership share, clearly bears on the likely success of the pro rata regime in preventing corporations from externalizing their costs.

Finally, a definitive comparative assessment of the control-based liability regime with the pro rata regime and limited liability regimes also would require empirical investigation into the ownership composition of corporations. For example, if a significant proportion of public corporations have controlling shareholders that hold significantly less than $100 \%$ of shares, then it is likely that a control-based regime would be more successful than the pro rata regime in compelling corporations to internalize their costs. However, if corporations generally are owned almost $100 \%$ by a corporation or individual shareholder, or if they have no controlling shareholder at all, the advantages of the control-based liability regime over a pro rata regime would be reduced. Similarly, the advantages of the control-based regime would be reduced if corporations attempt to externalize costs significantly despite the absence of a controlling shareholder. Finally, if many corporate activities are uninsurable, the possibility that a control-based liability regime would overdeter those activities would be more significant.

At base, however, a thorough consideration of shareholder liability issues cannot presume that all shareholders are identical. Developing an appropriate solution must include not only a more detailed empirical investigation, but also a consideration of the special position of the shareholder with the capacity to control. 